University at Buffalo School of Law

Digital Commons @ University at Buffalo School of Law

2013

\title{
An Intersystemic View of Intellectual Property and Free Speech
}

\author{
Mark Bartholomew \\ University at Buffalo School of Law \\ John Tehranian \\ Southwestern Law School
}

Follow this and additional works at: https://digitalcommons.law.buffalo.edu/journal_articles

Part of the First Amendment Commons, Intellectual Property Law Commons, and the Internet Law Commons

\section{Recommended Citation}

Mark Bartholomew \& John Tehranian, An Intersystemic View of Intellectual Property and Free Speech, 81 Geo. Wash. L. Rev. 1 (2013).

Available at: https://digitalcommons.law.buffalo.edu/journal_articles/47

\section{C) ${ }_{\text {COPYRIGHT }}^{\text {N }}$}

This Article is brought to you for free and open access by the Faculty Scholarship at Digital Commons @ University at Buffalo School of Law. It has been accepted for inclusion in Journal Articles by an authorized administrator of Digital Commons @ University at Buffalo School of Law. For more information, please contact lawscholar@buffalo.edu. 


\title{
An Intersystemic View of Intellectual Property and Free Speech
}

\author{
Mark Bartholomew* \\ John Tehranian**
}

\begin{abstract}
Intellectual property regimes operate in the shadow of the First Amendment. By deeming a particular activity as infringing, the law of copyright, trademark, and the right of publicity all limit communication. As a result, judges and lawmakers must delicately balance intellectual property rights with expressive freedoms. Yet each of these intellectual property regimes strikes the balance between ownership rights and free speech in a dramatically different way. This Article represents the first systematic effort to detail, analyze, and explain the divergent evolution of expression-based defenses in copyright, trademark, and right of publicity jurisprudence.

The first Part of this Article carefully details the disparate treatment of First Amendment defenses in the three intellectual property regimes. On one side of the spectrum is copyright law. Many factors have rendered copyright law a feeble protector of free expression. On the other side of the spectrum is the recent right of publicity jurisprudence, which routinely invokes the First Amendment and features robust defenses. Somewhere in the middle stands trademark law, offering its own judge-made defenses but simultaneously closing off those defenses for defendants engaging in commercial activity or activity that is potentially confusing to consumers.

The next Part attempts to explain why these three regimes accommodate the First Amendment in such different ways. The Article concludes that the divergence is not the result of careful deliberation, but rather the inadvertent product of different methods and histories of lawmaking. Because this divergence does not represent a logical or deliberate choice, reforms are needed. By bringing these different approaches to the First Amendment into relief, this Article demonstrates that some free speech interests are being shortchanged and aims to place all three regimes on a stronger theoretical footing.
\end{abstract}

* Professor of Law, SUNY Buffalo Law School.

** Irwin R. Buchalter Professor of Law, Southwestern Law School and Biederman Entertainment and Media Law Institute, Los Angeles, California. We would like to thank Jonas Anderson, Christine Haight Farley, William Gallagher, Deborah Halbert, Jacqui Lipton, Lisa Ramsey and participants at presentations at American University's Washington College of Law and the 2011 Law \& Society Annual Meeting for their suggestions and Nicole Haimson and Frances Stephenson for their valuable research assistance.

January 2013 Vol. 81 No. 1 


\section{TABle of Contents}

INTRODUCTION ................................... 3

I. Divergent Approaches to Free Expression in Copyright, Right of Publicity, and

Trademark Law ............................. 8

A. Copyright and the First Amendment ............. 9

1. Eschewing Direct Invocation of the

First Amendment ....................... 9

2. Conceptualizing Fair Use qua Necessity ....... 13

a. Applying the Parody/Satire Distinction...... 14

b. Negating Newsworthiness ............... 18

3. Considering the Role of the Marketplace...... 21

a. Defining Commercial Use............... 22

b. Elevating Market Harm ................. 24

B. The Right of Publicity and the First Amendment.... 29

1. Invoking the First Amendment ............ 30

2. Replacing Necessity with a Broad Conception of Transformation....................... 32

a. The Primacy of Transformation.......... 32

b. Protecting Newsworthy Uses ............. 35

3. Discounting Market-Based Harms ............ 37

C. Trademark and the First Amendment ............ 41

1. Addressing the First Amendment............ 41

2. Fair Use Defenses and Necessity ............ 44

3. The Rogers Test and Commerciality ......... 47

II. Explaining the Divergent Evolution of Free Speech Defenses in Intellectual Property Law .. 54

A. Justifying the Plaintiff's Right ................. 60

B. Judicial Perceptions of Litigants and the Value of Their Interests............................... 64

C. Categorizing the Speech Interests at Stake ......... 66

1. Content-Based or Content-Neutral? .......... 67

2. Considering the Defendant's Speech.......... 69

D. Common Law Versus Statutory Lawmaking ....... 71

1. Publicity Rights and the Making of Common Law ........................ 72

2. Copyright and the Limits of Statutory Lawmaking $\ldots \ldots \ldots \ldots \ldots \ldots \ldots \ldots \ldots \ldots, \quad 74$

3. Trademark Law: Statutory and Common Law Hybridity .......................... 79

E. The Influence of Tradition .................... 83

1. Precedent and Path Dependence ............. 83

2. Using History to Address Free Speech ........ 86

Conclusion ....................................... 90 


\section{INTRODUCTION}

Intellectual property rights and the First Amendment pull in opposite directions. Whereas the First Amendment prevents the suppression of speech, someone else's speech is foreclosed every time holders of copyright, trademark, or publicity rights exercise their rights. ${ }^{1}$ Although multiple scholars have identified this tension between intellectual property and free expression, ${ }^{2}$ there are still important and uncharted areas ripe for analysis. This Article explores one such area: the divergent evolution of expression-based defenses in trademark, copyright, and right of publicity jurisprudence. Each of these three intellectual property regimes accommodates free speech concerns in a radically different way. This disparity is not just interesting for its own sake. It also illustrates how, perhaps unbeknownst to lawmakers, history and the difference between common law and statutory lawmaking can produce strikingly different results between similar legal entitlements.

Every body of intellectual property law makes doctrinal adjustments in response to the need for free expression. ${ }^{3}$ These adjustments

1 Golan v. Holder, 132 S. Ct. 873, 890 (2012) ("[S]ome restriction on expression is the inherent and intended effect of every grant of copyright." (citing Eldred v. Ashcroft, 537 U.S. 186, 218-21 (2003))); Eugene Volokh, Freedom of Speech and Intellectual Property: Some Thoughts After Eldred, 44 Liquormart, and Bartnicki, 40 Hous. L. Rev. 697, 698 (2003).

2 See, e.g., Michael D. Birnhack, Copyright Law and Free Speech After Eldred v. Ashcroft, 76 S. CAL. L. Rev. 1275, 1275-77 (2003); Laura A. Heymann, The Public's Domain in Trademark Law: A First Amendment Theory of the Consumer, 43 GA. L. REv. 651, 673 (2009); Roberta Rosenthal Kwall, A Perspective on Human Dignity, the First Amendment, and the Right of Publicity, 50 B.C. L. Rev. 1345, 1347 (2009); Neil Weinstock Netanel, Locating Copyright Within the First Amendment Skein, 54 STAN. L. REV. 1, 2-4 (2001); David S. Olson, First Amendment Based Copyright Misuse, 52 WM. \& MARY L. REv. 537, 537 (2010); see also David McGowan, Why the First Amendment Cannot Dictate Copyright Policy, 65 U. PitT. L. Rev. 281, 281 (2004) ("For over thirty years scholars have suggested ways judges might use the First Amendment to limit Congress's power to grant authors exclusive rights in their works.").

3 Patent law does not routinely confront expressive interests in the same way that copyright, trademark, and the right of publicity all do, and, hence, this Article does not address it separately. "Indeed, as patents have traditionally been used, they have posed no problems to First Amendment rights." Krysta Kauble, Comment, Patenting Everything Under the Sun: Invoking the First Amendment to Limit the Use of Gene Patents, 58 UCLA L. Rev. 1123, 1155 (2011). In fact, most patents arguably further free speech interests by publicly introducing new inventions. See id. Nevertheless, patent rights can trigger free speech concerns, particularly as the subject matter of patent law has spread to cover potentially expressive activity like business methods and software design. See Dan Burk, Patenting Speech, 79 Tex. L. Rev. 99, 142-45 (2000). Although a review of existing caselaw has uncovered no patent invalidated or patent infringement suit denied on First Amendment grounds, such an argument has been made in some important patent law dissents. See Lab. Corp. of Am. Holdings v. Metabolite Labs., Inc., 548 U.S. 124, 127-28 (2006) (Breyer, J., dissenting); In re Bilski, 545 F.3d 943, 1005 (Fed. Cir. 2008) (Mayer, J., dissenting); see also Ass'n for Molecular Pathology v. U.S. Patent \& Trademark 
differ greatly depending on the intellectual property regime at issue. A representative example of the current state of the copyright/free expression interface is Henley v. DeVore,${ }^{4}$ a 2010 decision arising out of a dispute between musician and activist Don Henley and conservative politician Charles "Chuck" DeVore. 5 During the course of his 2010 campaign to gain the Republican nomination and challenge Barbara Boxer for her United States Senate seat in California, DeVore produced two videos that he uploaded to YouTube. ${ }^{6}$ The first video featured a song entitled "The Hope of November," a sendup of Henley's nostalgic megahit "The Boys of Summer." "The Hope of November" combined a karaoke simulation of the instrumental track from "The Boys of Summer" with new lyrics that critiqued Barack Obama, Nancy Pelosi, and their supporters-such as Henley. ${ }^{8}$ In the process, the song played on Henley's famous musings about the "Deadhead sticker on a Cadillac" and the composition's apparent themes of disillusionment with the false promises of 1960s activism. ${ }^{9}$ The second video featured a song entitled "All She Wants to Do Is Tax," a takeoff on Henley's deceptively lighthearted "All She Wants to Do Is Dance."10 "All She Wants to Do Is Tax" combined an instrumental simulation of "All She Wants to Do Is Dance" with lyrics critiquing liberal tax-and-spend policies. ${ }^{11}$ In the process, the song played on the original composition's apparent theme of blithe indifference and Band-Aid problem solving in the wake of political turmoil. ${ }^{12}$

The court granted summary judgment to DeVore on a trademark claim brought under the Lanham Act, but found for Henley on the

Office, 702 F. Supp. 2d 181, 238 (S.D.N.Y. 2010) (patenting of DNA sequences challenged as an unconstitutional restriction on speech).

4 Henley v. DeVore, 733 F. Supp. 2d 1144 (C.D. Cal. 2010). Disclaimer: one of the authors of this Article served as counsel in the Henley case.

5 Id. at $1147-48$.

6 See id. at $1148-49$.

7 Id. at 1147-48. "Boys of Summer" was co-written with Mike Campbell of Tom Petty \& the Heartbreakers fame.

8 See id. at $1148,1156$.

9 See id. at 1148, 1156-57.

10 See id. at 1148-49. Although most famously performed by Don Henley, "All She Wants to Do Is Dance" was written by noted composer Danny Kortchmar. Id. at 1148.

11 See id. at $1148-49,1158$.

12 See id. at $1148,1157-58$. Henley explains that the song was inspired by the politically charged climate of the time. He revealed that the last verse of "The Boys of Summer" was intended to "change things by protesting and making firebombs and growing [their] hair long and wearing funny clothes." However, he ultimately believed that his song had a marginal impact. He maintained that "after all [their] marching and shouting and screaming didn't work, [they] withdrew and became yuppies." See Mikal Gilmore, Henley Interview 1987, Roluing STONE, Nov. 5, 1987, at 287. 
two copyright infringement claims. ${ }^{13}$ Although thoughtfully constructed and eminently well reasoned, the ruling hewed closely to problematic copyright precedent that precludes independent consideration of the First Amendment interests at play in the use of creative content. Most prominently, the court characterized the videos as satires rather than parodies, thereby limiting DeVore's chances of satisfying a fair use defense. ${ }^{14}$ It also held that the use could harm the potential market for Henley's songs and that the use was "commercial" because the videos, despite their political nature, could inspire viewers to donate to DeVore's campaign. ${ }^{15}$ Copyright law's narrow definition of transformative use, its concomitant preference for parody over satire, its expansive definition of commercial activity, and its fixation on potential market harm of any stripe doomed DeVore. Notably, the court spent little time in its opinion specifically considering the First Amendment, even though DeVore's activities indisputably constituted an act of political speech. ${ }^{16}$

Compare Henley to Winter $v$. DC Comics, ${ }^{17}$ a recent right of publicity suit before the California Supreme Court. ${ }^{18}$ As part of its popular "Jonah Hex" series, DC Comics published two comic books featuring two villains named Johnny and Edgar Autumn. ${ }^{19}$ The nefarious duo was "half-worm, half-human offspring born from the rape of their mother by a supernatural worm creature that had escaped from a hole in the ground." 20 In the comics, they were depicted with "pale faces and long white hair." ${ }^{21}$ One of the villains was drawn wearing a stovepipe hat. ${ }^{22}$

Johnny and Edgar Winter, two musicians, sued for violation of their publicity rights. ${ }^{23}$ As the Winter brothers pointed out, they had long white hair, pale features, and one of them performed in a tall black top hat-all features suspiciously reminiscent of the Autumn characters. ${ }^{24}$ There was also the obvious similarity in names ("Johnny

13 See Henley, 733 F. Supp. 2d at 1164. The court left for trial the issue of whether DeVore's infringement was willful. See id. at 1166.

14 See id. at 1163.

15 See id. at $1158-59$.

16 See id. at 1154.

17 Winter v. DC Comics, 69 P.3d 473 (Cal. 2003).

18 See id. at 475.

19 See id. at 476.

20 Id.

21 Id.

22 See id.

23 See id.

24 See id. 
and Edgar Autumn" versus "Johnny and Edgar Winter"). ${ }^{25}$ All of these commonalities, the Winters claimed, meant that DC Comics had appropriated their names and likenesses in violation of California's right of publicity law. 26

The court, however, found the potential appropriation of the Winter brothers' personae by DC Comics irrelevant in the face of First Amendment concerns. In sharp contrast to the Henley decision, the Winter court immediately observed "[a]n obvious tension . . . between this right of publicity and the First Amendment." 27 The court then mused that resolution of the tension in the particular case "is not difficult," and ruled in favor of DC Comics. ${ }^{28}$ In coming to this decision, the court emphasized that the comic book depictions contained "significant expressive content." 29 In the process, the court rejected the Winters' argument that, as satires and not parodies, the comics were entitled to a lesser level of First Amendment protection. ${ }^{30}$ Indeed, the court labeled the parody/satire distinction "irrelevant" in the publicity rights context. ${ }^{31}$ The court also shrugged off concerns that these depictions could financially harm the Winters or that DC Comics had been motivated to use their names and likenesses in an effort to sell more comic books. ${ }^{32}$ It explained, "The question is whether the work is transformative, not how it is marketed. If the work is sufficiently transformative to receive legal protection, it is of no moment that the advertisements may have increased the profitability of the work." ${ }_{33}$ In the end, DC Comics enjoyed a summary judgment victory on First Amendment grounds that precluded any evaluation of the Winters' actual publicity rights claim. ${ }^{34}$

The Henley and Winter decisions demonstrate the dramatically divergent paths of copyright and the right of publicity when it comes to negotiating the interface between intellectual property rights and the First Amendment. Indeed, when confronted with competing intellectual property claims involving the same act of infringement, the courts have sometimes bifurcated their analysis, privileging the rights

25 See id.

26 See id. at $475-76$.

27 Id. at 475.

28 See id. at $479-80$.

29 Id. at 479.

30 See id.

31 See id.

32 See id.

33 Id. (internal quotation marks and citations omitted).

34 See id. at 480. 
of the copyright holder over expressive concerns while immunizing, on First Amendment grounds, the same defendant from trademark or publicity rights infringement claims. ${ }^{35}$

Part I of this Article charts the contours of this remarkable and underappreciated doctrinal divergence in copyright, trademark, and right of publicity jurisprudence. Courts often devote large portions of their analysis in publicity rights cases to wrestling with First Amendment issues. ${ }^{36}$ By contrast, judges have preferred to manage expressive concerns in copyright and trademark disputes through internal doctrinal mechanisms, rather than directly applying the First Amendment. ${ }^{37}$ Moreover, on a battery of different factors-defining transformative uses, ${ }^{38}$ carving out a role for news gathering, ${ }^{39}$ assessing the commerciality of the defendant's conduct, ${ }^{40}$ and evaluating potential economic harm to the rights holder ${ }^{41}$ each intellectual property regime has taken a different path. These doctrinal choices have had a profound impact on the amount and nature of expressive activity available to non-rights holders.

Part II of this Article tries to account for these differences. Copyright, trademark, and right of publicity law all restrict speech. While fundamental differences may exist among these three forms of intellectual property, their disparate treatment of First Amendment defenses does not appear to be the product of careful judicial consideration. Rather, the divergence appears to be the product of the particular lawmaking process unique to each intellectual property

35 See, e.g., Walt Disney Prods., Inc. v. Air Pirates, 581 F.2d 751, 758-59 (9th Cir. 1978) (affirming grant of summary judgment for plaintiff and rejecting fair use and First Amendment defenses on copyright claim but denying summary judgment on trademark infringement claim); Ty, Inc. v. Publ'ns. Int'l Ltd., No. 99 C 5565, 2000 WL 1499449, at *9, *15 (N.D. Ill. Oct. 6, 2000) (rejecting defendant's fair use and First Amendment defenses and granting plaintiff's motion for summary judgment on copyright claim while refusing to grant summary judgment on plaintiff's trademark infringement claim), rev'd, 292 F.3d 512 (7th Cir. 2002); Jackson v. MPI Home Video, 694 F. Supp. 483, 492 (N.D. Ill. 1988) (issuing preliminary injunction against defendant for copyright infringement yet refusing to grant such an injunction on publicity rights claim); see also Eldred v. Reno, 239 F.3d 372, 376 (D.C. Cir. 2001) (stating that copyright law does not raise "the same concern under the First Amendment" of suppressing ideas as trademark law); Dillinger, LLC v. Elec. Arts Inc., 795 F. Supp. 2d 829, 836, 838 (S.D. Ind. 2011) (granting motion for dismissal of right of publicity claim on basis that material was protected under First Amendment, but refusing to dismiss accompanying trademark claim).
36 See infra Part I.B.1.
37 See infra Part I.A.1, I.C.1.
38 See infra Part I.A.2, I.B.2, I.C.2.
39 See infra Part I.A.2.b, I.B.2.b.
40 See infra Part I.A.3, I.B.3, I.C.3.
41 See infra Part I.A.3, I.B.3, I.C.3. 
right. The statutory nature of modern copyright and trademark law holds judges hostage to a cramped view of speakers' downstream rights, while the common law nature of publicity rights enables a more robust response to threats to free expression. ${ }^{42}$ Each regime's historical tradition plays a role as well. Copyright's relatively long history operates as a baseline referent that forecloses attempts to leaven authorship rights. ${ }^{43}$ The right of publicity's brief existence, on the other hand, allows for rapid adaptation to new modes of expression..$^{44}$ Trademark law has a mixed record, at times able to produce new doctrinal mechanisms to accommodate speech but then narrowly interpreting those mechanisms according to longstanding views of the purpose of trademark law. ${ }^{45}$ Grappling with these differences is not merely an academic question. By comparing and contrasting these regimes on a crucial issue, this Article illuminates current blind spots in intellectual property jurisprudence and hopes to spark further conversations about which regime offers the best template for reform.

\section{Divergent Approaches to Free Expression in Copyright, Right of Publicity, and Trademark Law}

Copyright, trademark, and the right of publicity are all categorized as "intellectual property." 46 Defendants deemed to infringe one of these rights may be judicially barred from speaking in the way they wish or may be subject to substantial penalties based on their choice of expression. ${ }^{47}$ Because they can prevent someone from using particular language or images, all three of these regimes implicate the First Amendment. Yet, stark differences exist in the way these three regimes address defenses that claim the allegedly infringing activity constitutes a form of constitutionally protected free expression. This Article begins with copyright law.

42 See infra Part II.D.

43 See infra Part II.E.

44 See infra Part II.E.

45 See infra Part II.E.

46 See, e.g., Margreth Barrett, Intellectual Property 2 (3d ed. 2007); Laura R. Bradford, Parody and Perception: Using Cognitive Research to Expand Fair Use in Copyright, 46 B.C. L. Rev. 705, 710 (2005).

47 See, e.g., Eugene Volokh \& Brett McDonnell, Freedom of Speech and Independent Judgment Review in Copyright Cases, 107 YALE L.J. 2431, 2445 (1998) ("[C]opyright law is clearly a speech restriction ...."). 


\section{A. Copyright and the First Amendment}

In copyright jurisprudence, courts have generally denied or given short shrift to constitutional concerns through a series of mechanisms. First, courts have eschewed any independent First Amendment review of copyright claims by finding that the inherent limitations of copyright doctrine-including the idea/expression dichotomy and the fair use defense-adequately address any free speech concerns. Second, courts have restricted the benefits of fair use to a narrow range of transformative works. In the process, they have frequently converted the defense into an inquiry on necessity - an analytical gambit that has attached liability to a broad range of expressive, nonparodic, transformative activities. As a result, satiric and news-related uses often fail to receive fair use protection, despite their expressive content. Third, courts have elevated market-based considerations to a primary role in the fair use calculus, even when weighing the countervailing expressive rights of the alleged infringer. In the process, expansive interpretations of what constitutes market harm to, and commercial use of, a copyrighted work lead to findings of liability even when any economic harm to the plaintiff is speculative at best and the defendant's use would be viewed as noncommercial in most other contexts.

\section{Eschewing Direct Invocation of the First Amendment}

Copyright law implicates art, books, and letters-the quintessential vehicles for traditional free expression. When copyright holders exercise their intellectual property rights, someone else's speech is foreclosed. ${ }^{48}$ Nevertheless, modern copyright jurisprudence has consistently denied the existence of any fundamental tension between the rights of individuals to engage in free speech and the rights of authors to secure exclusive property rights over their creative works. In its most salient pronouncements on copyright law, the Supreme Court has squarely rejected the idea of any incompatibility between First Amendment rights and intellectual property protection. Instead, the Supreme Court has repeatedly maintained that any potential tension with free speech is already addressed through two intrinsic limits on copyright: the idea/expression dichotomy and the fair use defense. ${ }^{49}$

48 See Volokh, supra note 1, at 698-99.

49 Besides its independent role in checking the scope of copyright protection, the idea/ expression dichotomy also bears on the fair use test. The second factor of the fair use test, which considers the nature of the copyrighted work, provides greater fair use protection to factual (idea-based) materials and lesser fair use protection to fanciful (expression-based) materials. See 17 U.S.C. \& 107(2) (2006); see also Stewart v. Abend, 495 U.S. 207, 237 (1990). 
Take for example Golan v. Holder,$^{50}$ the Court's most recent pronouncement on copyright and the First Amendment. In Golan, the Supreme Court heard a constitutional challenge to Congress's ability to restore copyright in works that had previously entered the public domain. ${ }^{51}$ Section 514 of the Uruguay Round Agreements Act restored copyright protection to preexisting works that are protected in their country of origin but were previously denied copyright protection in the United States for various technical reasons. ${ }^{52}$ Section 514 benefitted the estates of many foreign authors but simultaneously deprived thousands of artists, conductors, and filmmakers of the ability to use certain works. ${ }^{53}$ The Golan plaintiffs argued that section 514 violated the First Amendment because, among other things, it constituted a regulation of speech properly subject to heightened judicial scrutiny-scrutiny it could not withstand..$^{54}$

This argument was quickly rebuked. Justice Ginsburg, writing for the majority, explained that because section 514's resurrection of works in the public domain did not alter the "traditional contours" of copyright protection, further consideration of the First Amendment was unnecessary. ${ }^{55}$ Section 514 suddenly blocked the use of numerous works-perhaps millions-once freely available to all Americans. ${ }^{56}$ Yet Ginsburg confidently asserted that copyright law's internal checks-rather than heightened constitutional scrutiny-resolve any potential free speech issues. ${ }^{57}$

Ginsburg relied heavily on a previous Supreme Court decision, Eldred v. Ashcroft. ${ }^{58}$ The Eldred opinion, also authored by Ginsburg, rejected a First Amendment challenge to Congress's extension of all subsisting copyrights by a term of twenty years through the Sonny Bono Copyright Term Extension Act ("CTEA") of 1998.59 Although

50 Golan v. Holder, 132 S. Ct. 873 (2012).

51 See id. at 875.

52 See id. at 874 . Section 514 of the Act is codified at 17 U.S.C. $\$ 104$ A (2006). A work previously in the public domain may claim copyright protection under section 514 on any one of three grounds: (1) lack of copyright relations between the country of origin and the United States at the time of publication; (2) lack of subject matter protection for sound recordings fixed before 1972; and (3) failure to comply with U.S. statutory formalities. See 17 U.S.C. $\S 104 \mathrm{~A}(\mathrm{~h})(6)(\mathrm{B})-(\mathrm{C})$.

53 See Golan, 132 S. Ct. at 900, 904-05 (Breyer, J., dissenting).

54 See id. at 891 (majority opinion).

55 See id. at 890-91 (internal quotation marks omitted).

56 See id. at 904-05 (Breyer, J., dissenting).

57 See id. at 890-91 (majority opinion).

58 See id. at 889-91; Eldred v. Ashcroft, 537 U.S. 186 (2003).

59 See Eldred, 537 U.S. at 193, 222-23; Sonny Bono Copyright Term Extension Act, Pub. L. No. 105-298, 112 Stat. 2827 (1998) (codified in scattered sections of 17 U.S.C.). 
the Court in Eldred suggested that courts below spoke too broadly when stating that copyright cases are categorically immune from First Amendment challenges, ${ }^{60}$ its own holding was only slightly more confined. "[C]opyright's built-in free speech safeguards are generally adequate to address [any conflict with free speech rights],"61 Justice Ginsburg explained. This approach echoed that of Justice O'Connor's eighteen years earlier. In rejecting a First Amendment argument in Harper \& Row, Publishers, Inc. v. Nation Enterprises, ${ }^{62}$ O'Connor, writing for the majority, held that the Copyright Act $^{63}$ already embodied First Amendment protections through its "distinction between copyrightable expression and uncopyrightable facts and ideas, and the latitude for scholarship and comment traditionally afforded by fair use." 64

Both the idea/expression dichotomy and the fair use defense are codified in the Copyright Act. ${ }^{65}$ Given precedents like Golan, Eldred, and Harper \& Row, regardless of the manner in which a defendant utilizes a copyrighted work, lower courts are free to mechanistically apply statutory language to infringement claims while turning a blind eye to independent First Amendment consideration. Courts can claim that the idea/expression dichotomy and fair use defense do all of the

60 See Eldred, 537 U.S. at 221.

61 Id.; see also Eldred v. Reno, 239 F.3d 372, 375 (D.C. Cir, 2001) (citing N.Y. Times Co. v. United States, 403 U.S. 713, 726 n.* (1971) (Brennan, J., concurring) (indicating that copyright laws are not restrictions on freedom of speech, because "[c]opyright laws ... protect[] only form of expression and not the ideas expressed"). There is much to criticize in the Supreme Court's Eldred decision. The Court denoted a bright line between the constitutionally guaranteed right to make "one's own speech" and the far more attenuated ability to borrow "other people's speeches." Eldred, 537 U.S. at 221 ("The First Amendment securely protects the freedom to make-or decline to make-one's own speech; it bears less heavily when speakers assert the right to make other people's speeches." (emphasis added)). Such a clear divide is only artificially sustainable. All copyrighted speech inevitably builds upon the speech of others. As Jessica Litman has eloquently argued, "All authorship is fertilized by the work of prior authors, and the echoes of old work in new work extend beyond ideas and concepts to a wealth of expressive details. ... What others have expressed, and the ways they have expressed it, are the essential building blocks of any creative medium." Jessica Litman, Copyright as Myth, 53 U. PITT. L. REV. 235, 243-44 (1991). The authors do not believe that the Eldred majority's failure to recognize the iterative nature of authorship and its relevance to free expression is simply the product of poor reasoning. Rather, as will be discussed in Part II, elements of the generalized copyright lawmaking process have combined to minimize First Amendment concerns.

62 Harper \& Row, Publishers, Inc. v. Nation Enters., 471 U.S. 539 (1985).

63 Act for the General Revision of the Copyright Law, Pub. L. No. 94-553, 90 Stat. 2541 (1976) (codified as amended in scattered sections of 17 U.S.C.).

64 Harper \& Row, 471 U.S. at 560.

65 See 17 U.S.C. $\S 102(b)$ (2006) (stating that copyright protection does not extend to ideas); id. $\$ 107$ (setting out the fair use defense). 
necessary work in protecting free speech.66 Yet these two doctrines suffer serious shortcomings when it comes to immunizing unauthorized expression from liability. The inherent difficulty in separating ideas from expression makes the idea/expression dichotomy a poor substitute for the First Amendment. ${ }^{67}$ Meanwhile, the fair use defense fares little better. The defense, as codified in section 107 of the 1976 Copyright Act, requires judicial evaluation of at least four factors:

(1) the purpose and character of the use, including whether such use is of a commercial nature ...; (2) the nature of the copyrighted work; (3) the amount and substantiality of the portion used in relation to the copyrighted work as a whole; and (4) the effect of the use upon the potential market for or value of the copyrighted work. ${ }^{68}$

As demonstrated below, far from checking the scope of copyright to protect the expressive interests of the public, courts have construed these four factors in a way that expands (rather than diminishes) the copyright monopoly. ${ }^{69}$ This expansion has taken place as courts have tied the defense to necessity, broadly defined disfavored commercial uses, and placed disproportionate weight on (an expansive notion of) market harm.

66 See, e.g., L.A. News Serv. v. Tullo, 973 F.2d 791, 795 (9th Cir. 1997) ("Copyright law incorporates First Amendment goals by ensuring that copyright protection extends only to the forms in which ideas and information are expressed and not to the ideas and information themselves."); New Era Publ'ns Int'l, ApS v. Henry Holt \& Co., Inc., 873 F.2d 576, 584 (2d Cir. 1989) (noting that "the fair use doctrine encompasses all claims of [F]irst [A]mendment in the copyright field").

67 In contemplating the fuzzy nature of the idea/expression dichotomy, Judge Learned Hand once conceded that "[n]obody has ever been able to fix that boundary, and nobody ever can." Nichols v. Universal Pictures Corp., 45 F.2d 119, 121 (2d Cir. 1930). Reliance on such a vague standard is bound to have a chilling effect on those seeking to repurpose copyrighted expression. Cf. Reno v. ACLU, 521 U.S. 844, 870-72 (1997). Moreover, the idea/expression dichotomy gives cold comfort to artists and social commentators because sometimes, when mak ing an expressive point, no adequate substitute exists for using a particular copyrighted expression (i.e., work). Describing the amateur video of the Kennedy assassination, Michael D. Birnhack once observed: "[I]n the welter of conflicting versions of what happened that tragic day in Dallas, the Zapruder film gave the public authoritative answers that it desperately sought; answers that no other source could supply with equal credibility.... [I]t was only the expression, not the idea alone, that could adequately serve the needs of an enlightened democratic dialogue." 4 Melville B. Nimmer \& David Nimmer, Nimmer on Copyright \& 19E.03[A][2] (2005).

6817 U.S.C. § 107.

69 For further discussion, see John Tehranian, Et Tu, Fair Use? The Triumph of NaturalLaw Copyright, 38 U.C. DAvis L. REv. 465, 466, 487 (2005) (arguing that, by reintroducing natural rights elements into the copyright calculus and focusing more on what is taken from a copyright holder than what use is made with the copyrighted work, the fair use test has actually served to increase, rather than check, the copyright monopoly). 


\section{Conceptualizing Fair Use qua Necessity}

Courts interrogating trademark and right of publicity claims recognize robust defenses for transformative and artistic uses of another's persona or trademark. ${ }^{70}$ Yet in copyright cases, transformative use and artistic repurposing enjoy only a small voice in the fair use calculus. Three out of the four elements in the fair use defense-the nature of the original work, the amount and substantiality of the original work used, and the market harm to the original ${ }^{71}$-focus on what is taken from the allegedly infringed work and author, rather than on the use made by the alleged infringer. Consideration of the expressive rights of a copyright user, as embodied in the transformative use doctrine, occurs through only one of the section 107 factors: "the purpose and character of the use." 72

Admittedly, on a rhetorical level, transformative use has grown increasingly important in recent years. ${ }^{73}$ In Campbell v. Acuff-Rose Music, Inc., ${ }^{74}$ the Supreme Court extensively cited and adopted the reasoning of Judge Pierre Leval's influential article, Toward a Fair Use Standard, ${ }^{75}$ in which Leval advocates for stronger consideration of transformation in the fair use test. ${ }^{76}$ Leval's article suggested that transformative uses of all kinds-whether to parody a copyrighted work itself or to invoke a copyrighted work for satirical, news reporting, or other purposes-should be entitled to fair use protection. ${ }^{77}$ Parts of the Campbell decision seem to adopt Leval's solicitude toward both parodic and nonparodic expressive uses of copyrighted work. For example, in one passage, the Court seemingly extended a generous definition of "transformative" to works that do not "merely 'supersede[ ] the objects' of the original creation" but "instead add[ ] something new, with a further purpose or different character, altering the first with new expression, meaning, or message." 78 Observers have either hailed ${ }^{79}$ or criticized ${ }^{80}$ this move as a dramatic reinvigoration of the fair use defense.

70 See infra Part I.B-C.

71 See 17 U.S.C. $\S 107$.

72 Id.

73 See Neil Weinstock Netanel, Making Sense of Fair Use, 15 Lewis \& CLARK L. Rev. 715, 736-40 (2011) (documenting dramatic increase in use of transformative use doctrine since 2005).

74 Campbell v. Acuff-Rose Music, Inc., 510 U.S. 569 (1994).

75 Pierre N. Leval, Toward a Fair Use Standard, 103 Harv. L. Rev. 1105, 1116 (1990).

76 See Campbell, 510 U.S. at 576, 578-79, 586-87, 591.

77 See Leval, supra note 75, at 1111-12 (enumerating examples of transformative uses, including "parody, symbolism, aesthetic declarations, and innumerable other uses").

78 Campbell, 510 U.S. at 579.

79 See, e.g., Pierre N. Leval, Campbell v. Acuff-Rose: Justice Souter's Rescue of Fair Use, 
In reality, however, Campbell's radical potential has been greatly exaggerated. In defining transformative, Campbell distinguishes between satire and parody. ${ }^{81}$ This distinction-a key point of departure between copyright and the other intellectual property regimes discussed in this Article-reduces fair use to a test about necessity. ${ }^{82} \mathrm{By}$ allowing borrowing only when conditions absolutely require it and by casting fair use as a privilege rather than a right, courts have transformed copyright into a more Blackstonian, absolute form of property. ${ }^{83}$ The focus on necessity also minimizes the expressive value of news-related uses of copyrighted material, despite the heightened First Amendment protection that courts have typically given to speech about public issues in other contexts. ${ }^{84}$

\section{a. Applying the Parody/Satire Distinction}

In dicta, the Campbell opinion describes the difference between parody and satire as follows:

For the purposes of copyright law, the nub of definitions, and the heart of any parodist's claim to quote from existing material, is the use of some elements of a prior author's composition to create a new one that, at least in part, comments on

13 CARdozo Arts \& ENT. L.J. 19, 19, 22-23 (1994) (praising elevation of transformation in fair use analysis with the Supreme Court's decision in Campbell); Jennifer E. Rothman, Liberating Copyright: Thinking Beyond Free Speech, 95 Cornell L. Rev. 463, 490 (2010) (describing scholars who have advocated implementing a transformativeness standard to expand fair use); see also On Davis v. Gap, Inc., 246 F.3d 152, 174 (2d Cir. 2001) (citing Campbell, 510 U.S. at 578-79) (describing transformativeness as "[t]he heart of the fair use inquiry").

80 See, e.g., Laura G. Lape, Transforming Fair Use: The Productive Use Factor in Fair Use Doctrine, 58 ALB. L. REv. 677, 712-722 (1995) (decrying elevation of transformation in fair use analysis with the Supreme Court's decision in Campbell).

81 See Campbell, 510 U.S. at 580-81.

82 See id. at 589.

83 Moreover, "[u]nder a utilitarian vision of copyright, progress in the arts, rather than a necessity calculus, should drive the fair use doctrine. As a consequence, there is no inherent reason that satire should have different fair use rights than parody." Tehranian, supra note 69, at 498. In fact, if one subscribed to Ernest Hemingway's views on the matter, parody should receive no special protection (and certainly no more than satire). Hemingway vehemently denied the transformative or productive value of parody: "The parody is the last refuge of the frustrated writer," he decreed. "Parodies are what you write when you are associate editor of the Harvard Lampoon. The greater the work of literature, the easier the parody. The step up from writing parodies is writing on the wall above the urinal." A.E. Hotchner, PApa Hemingway: A PerSonAl Memoir 70 (1960). But see Suntrust Bank v. Houghton Mifflin Co., 268 F.3d 1257, 1277 (11 th Cir. 2001) (Marcus, J., concurring) (noting that "[p]arodies and caricatures ... are the most penetrating of criticisms" (internal quotation marks omitted)).

84 See, e.g., N.Y. Times Co. v. Sullivan, 376 U.S. 254, 279-80 (1964) (requiring, on First Amendment grounds, that plaintiffs demonstrate actual malice to prevail on defamation claims involving speech about public officials). 
that author's works. If, on the contrary, the commentary has no critical bearing on the substance or style of the original composition, which the alleged infringer merely uses to get attention or to avoid the drudgery in working up something fresh, the claim to fairness in borrowing from another's work diminishes accordingly (if it does not vanish) . . . ${ }^{85}$

The Court went on to explain that "[p]arody needs to mimic an original to make its point ... whereas satire can stand on its own two feet." 86

This language indicates that secondary use of a copyrighted work must do more than add something new to the world of expression. ${ }^{87}$ Instead, the original work must be necessary to the defendant's expressive point. ${ }^{88}$ If the judge can hypothesize an alternative mechanism for making that point, then the artist must adopt that alternative mechanism and relinquish use of the copyrighted work. ${ }^{39}$ This is the logic behind the parody/satire distinction. Successful parodies gain protection under the transformative use doctrine because they require use of the original to enable an audience to recognize the parody's subject. ${ }^{90}$ Yet satirical uses of copyrighted works do not receive such insulation from liability. ${ }^{91}$ As courts reason, satirists do not need to use the original work because they are making a larger point that does not specifically involve that work..$^{92}$ As a result, judges can easily envision alternative means of expressing the satirist's point. All told, courts will reluctantly tolerate as fair those uses that are necessary to produce a form of speech (parody, for example). But, they will generally not abide uses that are unnecessary to produce a form of speech (satire, for example)..$^{93}$

85 Campbell, 510 U.S. at 580 (citations omitted).

$86 I d$. at 580-81. This limiting language shows that, rather than boldly advancing the goal of free expression via fair use's purpose and character factor, Campbell actually cleaves to longstanding fair use precedent that has consistently favored parody over other transformative uses. Rebecca Tushnet, Copyright as a Model for Free Speech Law: What Copyright Has in Common with Anti-Pornography Laws, Campaign Finance Reform, and Telecommunications Regulation, 42 B.C. L. REv. 1, 26-27 (2000) (discussing fair use's preference for "criticism and parody" over other transformative uses).

87 See Campbell, 510 U.S. at $580-81$.

88 See id. at 580.

89 See id. at 589.

90 See id. at $580-81$.

91 See id. at 581.

92 See id.

93 The Court's parenthetical language leaves open the possibility of a limited protective berth for satire:

[W] hen there is little or no risk of market substitution, whether because of the large 
Lower courts interpreting Campbell have hewed to the parody/ satire distinction outlined above, giving carte blanche to parodists but providing little fair use refuge for other transformative users. For example, a book satirizing the O.J. Simpson murder trial in the style of Dr. Seuss's The Cat in the Hat failed the fair use test. ${ }^{94}$ On the first factor of the fair use inquiry the court virtually equated transformative use with parody, reasoning that because the book did not qualify as parody, it could not constitute transformative use. ${ }^{95}$ In another case, artist Jeff Koons found inspiration in a cheap postcard he saw in a tourist shop. ${ }^{96}$ The postcard, Puppies by Art Rogers, featured a photograph of a couple and some dogs posing in Rockwellian tranquility. ${ }^{97}$ Koons appropriated the depiction and accentuated various elements of the photograph to satirize suburban American aesthetic sensibilities. ${ }^{98}$ The district court rejected Koons's fair use defense, holding that his activities were not transformative because they did not criticize or comment upon Rogers's original photograph. ${ }^{99}$ On appeal, the Second Circuit affirmed:

It is the rule in this Circuit that though the satire need not be only of the copied work and may ... . also be a parody of modern society, the copied work must be, at least in part, an object of the parody, otherwise there would be no need to conjure up the original work. ${ }^{100}$

Because the defendant artist did not "need" the original work to make his expressive point, there could be no fair use. ${ }^{101}$

extent of transformation of the earlier work, the new work's minimal distribution in the market, the small extent to which it borrows from an original, or other factors, taking parodic aim at an original is a less critical factor in the analysis, and looser forms of parody may be found to be fair use, as may satire with lesser justification for the borrowing than would otherwise be required.

Id. at $580 \mathrm{n} .14$. Yet the lower courts have ignored this language in favor of a rigid distinction between parody and satire. See infra notes $94-101$ and accompanying text.

94 See Dr. Seuss Enters., L.P. v. Penguin Books USA, Inc., 109 F.3d 1394, 1396, 1403 (9th Cir. 1997).

95 See id. at 1401.

96 See Rogers v. Koons, 751 F. Supp. 474, 476 (S.D.N.Y. 1990).

97 See id. at 475.

98 See id. at 476, 479. As Koons's attorney, Martin Garbus, explained:

[Koons] saw sentimentality, inanity and kitsch. When he blew up the image to larger than life size, stuck daisies in the hair of the sickly sweet smiling couple (the flowers were not in the photograph) and painted the finished ceramic, the sculpture acquired a horrific quality quite distinct from the original.

Martin Garbus, Lolita and the Lawyers, N.Y. Times Book Rev., Sept. 26, 1999, at 35.

99 See Rogers, 751 F. Supp. at 479.

100 Rogers v. Koons, 960 F.2d 301, 310 (2d Cir. 1992).

101 See id. 
These decisions are not unreasonable given the limiting language in Campbell. Yet by myopically focusing on the parody/satire distinction, courts have failed to protect other forms of expression traditionally privileged under the First Amendment in other contexts. As noted previously, the Henley v. DeVore case involved two reworkings of Don Henley songs. The first, "All She Wants to Do Is Tax," was deemed a mere satire that mocked liberal tax-and-spend policies. ${ }^{102}$ As a consequence, the court found that DeVore did not need to utilize Henley's work in the project. ${ }^{103}$ After all, DeVore could have alternatively made his point about taxation policies by composing his own music, drawing on a public domain work, or using a work over which he had rights. ${ }^{104}$ The court even remarked that because "All She Wants to Do Is Tax" was so clearly not a parody, "[it] does not present a difficult question. ... [It] is clearly not fair use."105 For the second, "The Hope of November," the court acknowledged that DeVore's use of the copyrighted work "The Boys of Summer" was designed, at least in part, to lampoon Henley as an Obama supporter. ${ }^{106}$ As such, it may have contained sufficient parodic elements (as opposed to satiric ones) to necessitate use of Henley's song, even without permission. ${ }^{107}$ Nevertheless, the court ultimately rejected DeVore's fair use defense because DeVore's use "goes far beyond what is necessary to conjure up Henley to hold him up to ridicule." 108 In the end, using notions of necessity, the court rejected DeVore's fair use defense with respect to both works. Both of DeVore's videos constituted political speech that criticized partisan rivals and the ruling party in Congress. ${ }^{109}$ This consideration seems equally relevant to the "purpose and character" inquiry as the parody/satire distinction yet received little weight in the court's analysis. ${ }^{110}$

102 Henley v. DeVore, 733 F. Supp. 2d 1144, 1158, 1163 (C.D. Cal. 2010).

103 See id. at 1158.

104 See id. (arguing that DeVore had "innumerable alternatives with which to mock Boxer and her policies").

105 Id. at 1163.

106 See id. at 1163-64.

107 See id. at 1151-52, 1164 ("[T] he parodist needs to use at least some portion of the original because the effectiveness of parody depends on its ability to mimic or 'conjure up' the original .... The parodist has no alternative but to use the [original] work.").

108 Id. at 1164 (emphasis added).

109 See id. at 1148-49.

110 See id. at 1157-59. 


\section{b. Negating Newsworthiness}

The concept of necessity also plays a powerful role in limiting the types of news-related uses that qualify as transformative for the purposes of the fair use analysis. The Supreme Court's opinion in Harper $\&$ Row, the most relevant case on the matter, explicitly rejected any special First Amendment defense in copyright cases that raised issues of newsworthiness. ${ }^{111}$ Indeed, the materials at issue in Harper \& Row could not have been more newsworthy, not to mention politically relevant - they famously involved a publication featuring extensive outtakes from, and references to, the memoirs of former U.S. President Gerald Ford. ${ }^{112}$ Yet as the Court rather bluntly stated, "[t]he fact that an article arguably is 'news' and therefore a productive use is simply one factor in a fair use analysis" - and nothing more. ${ }^{113}$

To be fair, one might argue that Harper \& Row did not so much dismiss the import of news reporting as it simply recognized the nearly absolute right of first publication that belongs to a copyright holder. After all, in the case, Nation magazine had obtained a purloined copy of Ford's memoir and published its juiciest details before either Harper \& Row (the authorized publisher of the memoir) or Time magazine (the authorized prepublication excerpter) had their chance to hit the market first. ${ }^{114}$ But the logic of Harper \& Row has been extended far beyond protecting just the right of first publication. For example, Jesse Jackson used copyright law to prevent the distribution of his 1988 Democratic National Convention speech. ${ }^{115}$ Unlike the situation in Harper \& Row, the speech had already been publicly disseminated. Four television networks carried Jackson's live address and over one hundred copies of the speech were distributed to the press. ${ }^{116}$ Yet when an entrepreneur began selling videotapes of the speech days later, Jackson sued for copyright infringement. ${ }^{117}$ The court rejected the entrepreneur's fair use defense. It briefly acknowledged that "[s]elling the news" was potentially legitimate under the

111 See Harper \& Row, Publishers, Inc. v. Nation Enters., 471 U.S. 539, 557 (1985) ("The fact that the words the author has chosen to clothe his narrative may of themselves be 'newsworthy' is not an independent justification for unauthorized copying of the author's expression prior to publication.").

112 See id. at $543-44$.

113 See id. at 561; see also Monge v. Maya Magazines, Inc., 688 F.3d 1164, 1183 (9th Cir. 2012) (stating that "[w]aiving the news reporting flag is not a get out of jail free card in the copyright arena" and rejecting gossip magazine's fair use defense).

114 See id. at 543-44.

115 See Jackson v. MPI Home Video, 694 F. Supp. 483, 484-85 (N.D. Ill. 1988).

116 See id. at 485.

117 See id. at $485-87$. 
"purpose and character" factor. ${ }^{118}$ But it concluded that all of the other factors, particularly the effect of the use upon the potential market for Jackson's speech, weighed too far in Jackson's favor to allow a fair use defense. ${ }^{119}$ Brushing aside the defendant's contention that his conduct should be immunized for promoting the "public interest" and, therefore, favored under the First Amendment, the court explained that Supreme Court precedent did not countenance such an exception for newsworthy items. ${ }^{120}$ Quoting Harper \& Row, the court explained, "It is fundamentally at odds with the scheme of copyright to accord lesser rights in those works that are of greatest importance to the public.' "121 The court deemed this passage "fatal to the defendants' First Amendment argument."122 It also noted that a newsworthiness exception would be particularly inappropriate given the likelihood that Jackson "earns part of his living by being paid for his oratory." 123

Indeed, unmistakably news-related uses receive no special dispensation in copyright law, even when the defendant is careful not to appropriate the entire work. In 1997, in Los Angeles News Service $v$. KCAL-TV Channel 9,124 the Ninth Circuit considered the case of a news broadcast that used thirty seconds of a four-minute video capturing the infamous beating of Reginald Denny in Los Angeles in 1992.125 The district court had rejected claims of infringement by the footage's copyright holder, the Los Angeles News Service ("LANS"). ${ }^{126}$ As the district court reasoned, the allegedly infringed material "is a unique and newsworthy videotape of significant public interest and concern." 127 LANS had already exercised its right of first publication, thereby distinguishing the case from Harper \& Row. ${ }^{128}$ Another point that seemingly weighed in favor of fair use was that the defendant, KCAL, had actually sought a license from LANS, but LANS had refused. ${ }^{129}$

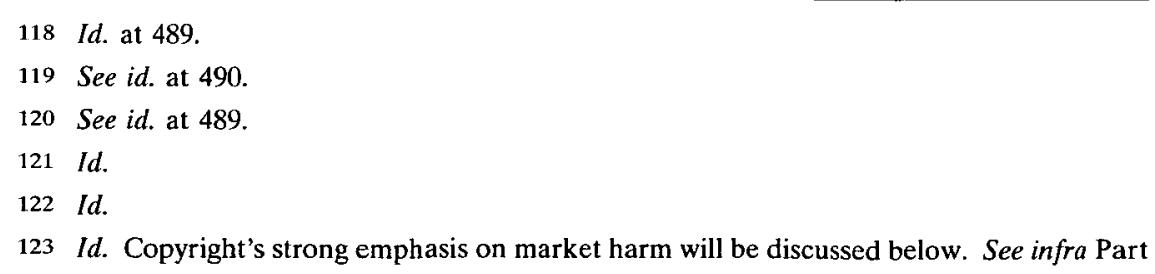


Nevertheless, the Ninth Circuit reversed the grant of summary judgment for KCAL and, in the process, relied heavily on the notion of fair use as a necessity-based defense. ${ }^{130}$ Given LANS's refusal to deal and what the court acknowledged was footage reflecting the Denny incident "from the best perspective of any witness," KCAL argued that it had no choice but to use the footage without authorization. ${ }^{31}$ The Ninth Circuit disagreed, concluding that there was no fair use, in part, because "there is no evidence that alternatives were not available." 132 Significantly, the court's focus lay on hypothetical alternatives, rather than an evaluation of the public access concerns at issue or the political and social speech at stake. ${ }^{133}$ Just as judges decline to protect satirical uses because they can envision other means of making the same expressive point, the $K C A L$ court found against a journalistic organization because it could hypothesize other ways of communicating the same news story.

Not all courts have failed to recognize fair use rights in the newsreporting context, however. For example, in Núñez v. Caribbean International News Corp. ${ }^{134}$ the First Circuit affirmed a district court's finding of fair use in a case involving a Puerto Rican newspaper's unauthorized reproduction of three controversial photographs of Miss Puerto Rico Universe 1997.135 The court emphasized the transformative nature of the use; while the photographs were originally meant for modeling portfolios, the defendant used the photographs to inform the public about a scandal involving Miss Puerto Rico Universe. ${ }^{136}$ Yet, even in finding for the defendant, the ruling hewed to the concept of fair use as vindicating rights by necessity. As the court noted, anything less than full use of the photographs would have been difficult (if not impossible) since "the pictures were the story." 137 The newspaper managed to deflect the photographer's copyright claim only because the court could envision no way to describe a controversy over the tastefulness of the photographs without using the photographs. ${ }^{138}$

All told, while defendants making news-related uses of copyrighted content may occasionally receive a last-minute reprieve

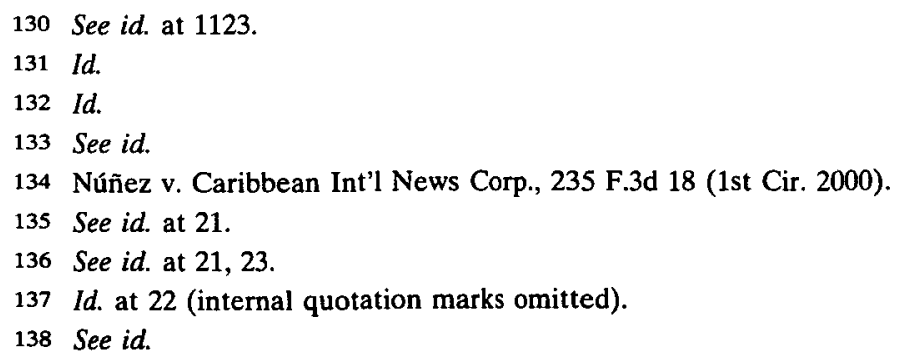


through the fair use defense, they would likely be foolish to rely upon such a result ex ante. All too regularly, to avert infringement liability, a defendant making a claim of newsworthiness must demonstrate that the use of a copyrighted work was absolutely necessary. As discussed later, and by sharp contrast, right of publicity jurisprudence takes an entirely different approach, fully immunizing news-related uses under a specialized defense that downplays and even shuns considerations of necessity. ${ }^{139}$

\section{Considering the Role of the Marketplace}

Finally, copyright law is unique among intellectual property regimes in that it places primacy on protecting a plaintiff's right to exploit potential licensing markets, even in the face of a First Amendment defense. In the process of balancing intellectual property rights with free expression, copyright doctrine hits "commercial" infringers with a double whammy. First, as noted before, transformative use represents only a part of one factor (the first) in the fair use test. ${ }^{140}$ The other portion of the first part of the fair use test assesses the economic nature of the use. ${ }^{141}$ Courts have disfavored commercial uses, which they have tautologically defined as those uses depriving the plaintiff of a potential licensing market. Second, the fourth factor in the fair use test explicitly examines the effect of the use on the market for the original work, and courts, taking their cue from the Supreme Court, have deemed this factor the most important in the fair use balancing test. ${ }^{142}$ As a result, this factor has often crowded out consideration of the other three. For example, in the $K C A L$ case described above, the court reasoned that a ruling of fair use would deprive the footage's copyright holder of valuable licensing revenuesrevenues which the court assumed should belong to the copyright holder in the first place. ${ }^{143}$ Hence, in $K C A L$ and other similar cases where a defendant arguably profits from a use or impacts a plaintiff's licensing market, two of the four factors (nature of the use and market harm) immediately weigh against a finding of fair use. Moreover, in interpreting these two factors, the courts have favored plaintiffs by

139 See infra Part I.B.2.b.

140 See supra note 72 and accompanying text.

141 See 17 U.S.C. $\$ 107(1)$ (2006) (calling for evaluation of "the purpose and character of the use, including whether such use is of a commercial nature").

142 See Harper \& Row, Publishers, Inc. v. Nation Enters., 471 U.S. 539, 566 (1985) (noting that market harm "is undoubtedly the single most important element of fair use"); see, e.g., Belmore v. City Pages, Inc., 880 F. Supp. 673, 679 (D. Minn. 1995).

143 See L.A. News Serv. v. KCAL-TV Channel 9, 108 F.3d 1119, 1122-23 (9th Cir. 1997). 
construing commerciality and market harm broadly. This Section describes how both the commercial/noncommercial distinction and the focus on potential market harms cabin consideration of the expressive interests often at play in copyright disputes.

\section{a. Defining Commercial Use}

The commercial/noncommercial distinction plays a central role in fair use jurisprudence, ${ }^{144}$ yet no one seems to know its true boundaries. Courts have stretched the definition of commercial use to include activities that ordinarily would not be viewed as commercial in any other context, especially when First Amendment rights are at issue. For example, in $A \& M$ Records, Inc. v. Napster, Inc.,${ }^{145}$ the Ninth Circuit held that peer-to-peer file sharing constituted commercial use of copyrighted materials. ${ }^{146}$ On the original Napster, users could share music files with other Internet users without paying Napster a dime, and could act as "leeches" and download music from other people's computers without reciprocating by opening up their file folders to other users. ${ }^{147}$ Yet the Ninth Circuit deemed such uses of copyrighted works commercial simply because "users [got] for free something they would ordinarily have to buy." 148 In Worldwide Church of God v. Philadelphia Church of God, Inc., ${ }^{149}$ the Ninth Circuit went one step further and held that giving away thirty thousand free copies of a religious work constituted a commercial activity because the defendant "profited" from the use of the work by attracting new members who might ultimately tithe to the church. 150

The logical extension of Napster and Worldwide Church is the Henley ruling, which drew upon these precedents to find that the use of copyrighted content in the context of a political campaign constituted commercial use. ${ }^{151}$ The Henley court pointed to a discussion of commercial use in Harper \& Row, which explained that "[ $t$ he crux of

144 See Barton Beebe, An Empirical Study of U.S. Copyright Fair Use Opinions, 1978-2005, 156 U. PA. L. Rev. 549, 602 (2008) (concluding that "a finding that [a] defendant's use was for a noncommercial purpose ... strongly influence[s]" the ultimate outcome in favor of a finding of fair use).

145 A \& M Records, Inc. v. Napster, Inc., 239 F.3d 1004 (9th Cir. 2001).

146 See id. at 1015.

147 See id. at 1011; see also Seth Schiesel, File Sharing's New Face, N.Y. Times (Feb. 12, 2004), http://www.nytimes.com/2004/02/12/technology/file-sharing-s-new-face.html?pagewanted= all\&src $=$ pm.

148 See Napster, 239 F.3d at 1015.

149 Worldwide Church of God v. Phila. Church of God, Inc., 227 F.3d 1110 (9th Cir. 2000).

150 See id. at $1113,1117-18$.

151 See Henley v. DeVore, 733 F. Supp. 2d 1144, 1158 (C.D. Cal. 2010). 
the profit/nonprofit distinction is not whether the sole motive of the use is monetary gain but whether the user stands to profit from exploitation of the copyrighted material without paying the customary price." 152 In determining whether DeVore profited from Henley's songs "without paying the customary price,"153 the court also noted that "monetary gain is not the sole criterion [of commerciality], particularly in a setting where profit is ill-measured in dollars." ${ }^{154}$ While the use may not have literally lined DeVore's pocketbook with cash, there was "profit" in that "DeVore ... stood to gain publicity and campaign donations from [his] use of Henley's music."15s "In fact," the court went on to explain, "the videos contained links directing viewers to the DeVore campaign website, encouraging them to donate. Thus, ... the Defendants 'profited' from their use by gaining an advantage without having to pay customary licensing fees to the Plaintiffs."156 Hence, despite their indisputably political nature, DeVore's activities were deemed commercial, thereby dealing a significant blow to his chance of success under a fair use defense.

These cases highlight the dangers inherent in the current amorphous definition of commerciality. By viewing profit as encompassing more than direct monetary gain, the courts have threatened to render all unpaid exploitations of copyrighted works "commercial" in nature. ${ }^{157}$ Infringing copyright can almost always lead to more attention from others and more attention can almost always be monetizedwhether through the sale of eyeballs via advertising, an increase in the value of a business, a growth in church attendance, or greater visibility for a political campaign. The fair use defense, however, should not entirely evaporate simply because the plaintiff is deprived of some potential revenue. Fair use inevitably causes some loss in potential revenue to someone, somewhere. Moreover, to the extent market harm is an appropriate consideration in the fair use test, such concerns are already covered by the fourth factor of the test and need not be redundantly considered in the first. ${ }^{158}$

152 Harper \& Row, Publishers, Inc. v. Nation Enters., 471 U.S. 539, 562 (1985).

153 Henley, 733 F. Supp. 2d at 1158 (internal quotation marks omitted).

154 Id. at 1159 (quoting Worldwide Church, 227 F.3d at 1117).

155 Id.

156 Id.

157 See Beebe, supra note 144, at 598 (discussing criticism of the commerciality inquiry, "primarily on the ground that nearly all expression in our culture is produced for profit or is otherwise income-producing in some sense").

158 The focus on whether or not users are paying the "customary price" for copyrighted works is also problematic. Specifically, this definition of commercial use conflates infringement with the fair use defense. If fair use truly represents an affirmative defense to infringement and 


\section{b. Elevating Market Harm}

The fourth factor of the fair use test is "the effect of the use upon the potential market for or value of the copyrighted work." 159 The prominence of this factor in the fair use analysis-the centerpiece of any fair use analysis according to the Supreme Court ${ }^{160}$-helps explain why copyright law ultimately provides less deference to free speech interests than other intellectual property regimes. ${ }^{161}$ This is especially the case since "market harm" is broadly defined to encompass theoretical markets that a copyright holder is unlikely to enter.

For example, in the Dr. Seuss case described above, the Ninth Circuit found that the defendant's use "hurt the potential market for the original and derivatives of The Cat in the Hat."162 Although it is difficult to imagine that Dr. Seuss Enterprises would ever contemplate entering the market for sendups of the O.J. Simpson trial, the court noted that, as an affirmative defense, the defendants had failed to meet their burden of demonstrating an absence of market harm. ${ }^{163}$ Similarly, when deciding whether to enjoin the publication of the novel 60 Years Later, an unauthorized sendup of J.D. Salinger's novel The Catcher in the Rye, the district court in Salinger v. Colting ${ }^{164}$ found

a stand-in for the First Amendment, it should be interpreted to grant individuals the right not to pay the customary price for a work, even if the activity constitutes infringement. In Napster, however, once the court determined that users did not pay the customary price for sharing music files, their behavior became "commercial" and, therefore, suspect. See A\&M Records, Inc. v. Napster, Inc., 239 F.3d 1004, 1015 (9th Cir. 2001). Similarly, once the religious and political activities at issue in Worldwide Church and Henley were deemed for profit, the chances of a successful fair use defense diminished appreciably. See Worldwide Church, 227 F.3d at 1119; Henley, 733 F. Supp. 2d at 1159.

15917 U.S.C. $\$ 107(4)$ (2006).

160 See Stewart v. Abend, 495 U.S. 207, 238 (1990); Harper \& Row, Publishers, Inc. v. Nation Enters., 471 U.S. 539, 566 (1985).

161 Before any analysis of fair use is even done in a copyright case, courts implicitly consider the issue of market harm to determine if a copyright was infringed in the first place. Copyright infringement requires substantial similarity between the original copyrighted work and the use. See, e.g., Funky Films, Inc. v. Time Warner Entm't Co., 462 F.3d 1072, 1075 (9th Cir. 2006). Substantial similarity is also a proxy for the fourth fair use factor. The more similar the two works, the more likely the secondary use will supplant the commercial market for the copyrighted work. Thus, by considering the issue of market harm in the fair use test (and particularly by elevating market harm over all other considerations in that test), a court largely duplicates its consideration of the threshold requirement of substantial similarity. By weighing the fair use scales in this way, courts favor the property rights of authors over the expressive interests of users.

162 Dr. Seuss Enters., L.P. v. Penguin Books USA, Inc., 109 F.3d 1394, 1403 (9th Cir. 1997).

163 See id.

164 Salinger v. Colting, 641 F. Supp. 2d 250 (S.D.N.Y. 2009), vacated on other grounds, 607 F.3d 68 (2d. Cir. 2010). 
harm to a potential market for derivatives of the original work. ${ }^{165}$ Salinger was a notorious recluse who categorically refused to publish anything for the last half century of his life. ${ }^{166}$ He never betrayed any interest in publishing a sequel to The Catcher in the Rye. ${ }^{167}$ Thus, it is highly unlikely that 60 Years Later would dilute a derivative market in which Salinger had no desire to participate. ${ }^{168}$ Yet, as the Salinger court explained,

although Salinger has not demonstrated any interest in publishing a sequel or other derivative work of Catcher, the Second Circuit has previously emphasized that it is the "potential market" for the copyrighted work and its derivatives that must be examined, even if the "author has disavowed any intention to publish them during his lifetime," given that an author "has the right to change his mind" and is "entitled to protect his opportunity to sell his [derivative works]." 169

Once again, the Henley decision nicely encapsulates these principles and the current state of copyright doctrine. In the last part of its fair use analysis, the court did not simply assess whether DeVore's use harmed or would harm the actual market for Henley's original works; instead, it asked whether widespread conduct of the type in which DeVore engaged threatened "the potential market for the originals or their derivatives." 170 It seems unlikely that, by using his songs in videos satirizing Democratic politicians, DeVore somehow harmed Henley economically. Not surprisingly, however, the court found that the videos threatened market harm. ${ }^{171}$ Use of others' work without authorization will always deprive them of revenue if a user were required to pay them for the right in the first place-an assumption the Henley court makes even though it is supposed to be answering that

165 See id. at 268.

166 See id. at $260-61$.

167 See id. at 268.

168 Of course, his Estate might do otherwise, though one suspects that his conditions on the testamentary grant of his copyrights will not allow it to do so. See Kenneth Slawenski, J.D. Salinger's Untold Stories: Tales of a Recluse, Huffington Post (Jan. 27, 2012, 8:22 AM), http:// www.huffingtonpost.com/kenneth-slawenski/jd-salinger-untold-stories_b_1234530.html.

169 Salinger, $641 \mathrm{~F}$. Supp. 2d at 268 (citations omitted).

170 Henley v. DeVore, 733 F. Supp. 2d 1144, 1151, 1161-62 (C.D. Cal. 2010).

171 See id. at 1162-63. The court could not be certain that the defendants' widespread use of "similar satirical spins" of the plaintiff's music "would not harm the market for the originals." Id. at 1162. Furthermore, the court found evidence that the defendants' use did in fact "supplant the [plaintiff's] market for derivatives," because other potential licensees would be deterred from using the plaintiff's work once it had already been used in the market. Id. at 1163 . The court described this type of injury as "the very essence of market substitution." Id. 
question through the fair use test. ${ }^{172}$ Moreover, when courts consider the loss in licensing opportunities for potential derivative marketseven ones that the plaintiff is unlikely to enter or has expressly denied interest in ${ }^{173}$-a finding of market harm becomes likely.

To be sure, the fair use calculus does not inevitably lead to findings of market harm for transformative uses. As Jay Dougherty has observed, transformative uses really come in two forms: transexpressive uses, where an original work is utilized for a new form of expression, and transpurposive uses, where an original work is set to a new purpose. ${ }^{174}$ In giving rise to such new artistic expressions as remixes, lampoons, mélanges, satires, parodies, or pastiches, transexpressive uses directly make speech. As discussed previously, in transexpressive cases involving satire, commentary, and criticism, courts have fretted about J.D. Salinger's (admittedly disavowed) potential interest in entering the market for a Catcher in the Rye sequel, ${ }^{175} \mathrm{Dr}$. Seuss's potential interest in licensing rights to his stories for use in mockeries of the O.J. Simpson trial, 176 and Don Henley's potential interest in licensing rights to his music for political lampoons. ${ }^{177}$

Transpurposive uses, on the other hand, employ original works in an entirely new communicative format, and, in the process, can aid First Amendment interests by improving public access to cultural content, information, and news. In such cases, the courts have not embraced such a broad reading of market harm. For example, in both

172 See id. at 1159 (using analogous reasoning set forth in Worldwide Church of God v. Philadelphia Church of God, Inc., 227 F.3d 1110, 1118 (9th Cir. 2000), the Henley court assumed "DeVore ... stood to gain publicity and campaign donations from [his] use of Henley's music" before it completed the entire fair use analysis).

173 See Balsley v. LFP, Inc., 691 F.3d 747, 761 (6th Cir. 2012); Salinger, 641 F. Supp. 2d at 268.

174 Conversation with Jay Dougherty, Professor of Law, Loyola Law Sch., in Irvine, Cal. (May 13, 2010).

175 See Salinger, 641 F. Supp. 2d. at 268 (holding against fair use with respect to the fourth factor by reaffirming the Second Circuit's assertion that an author's " 'potential market' for the copyrighted work and its derivatives [must] be examined" in spite of Salinger's expressed disinterest in publishing a sequel or other derivative work of The Catcher in the Rye), vacated on other grounds, 607 F.3d 68 (2d Cir. 2010)).

176 See Dr. Seuss Enters., L.P. v. Penguin Books USA, Inc., 109 F.3d 1394, 1403 (9th Cir. 1997) (weighing fourth factor against a finding of fair use in light of defendants' failure to submit evidence regarding plaintiff's relevant markets for potential licenses and stating that "a silent record on an important factor bearing on fair use disentitle[s] the proponent of the defense" (quoting Campbell v. Acuff-Rose Music, Inc., 510 U.S. 569, 594 (1994))).

177 See Henley, 733 F. Supp. 2d at 1162 (rejecting defendants' argument that "there is no market for licensed use of the works because the [p]laintiffs refuse to license their works," since plaintiffs previously licensed their works "for satirical or other commercials uses ... and intend to consider licensing their works in the future"). 
Kelly v. Arriba Soft Corp. ${ }^{178}$ and Perfect 10, Inc. v. Amazon.com, Inc., ${ }^{179}$ the Ninth Circuit found that the unauthorized use of reduced, lower-resolution copies (also known as "thumbnails") of copyrighted images in search engine technology constitutes fair use. ${ }^{180}$ In both instances, the court considered the defendants' conduct to be transpurposive and, in the process, downplayed any harm to the plaintiffs' licensing markets. In addressing Google's use of thumbnails of images copyrighted by Perfect 10, the court could have found that the creation of thumbnails for indexing use would potentially subject Perfect 10 to significant market harm. After all, thumbnails contain the essence of the copyrighted work and thus constitute derivatives thereof. Moreover, Perfect 10 may intend someday to enter the market for providing search engine services for its copyrighted works. But the court made no such findings. Instead, the Ninth Circuit held that the "potential harm to Perfect 10's market remains hypothetical"181_a fact that would typically give courts in transexpressive cases no pause in still finding for the plaintiff under the fourth fair use factor. ${ }^{182}$ The reason for this divergent treatment is likely based on the transpurposive nature of the use, as conceived by the court. Specifically, the court could comfortably disregard concerns of market harm because of its belief that Google's operations were fundamentally outside of what Perfect 10 could reasonably obtain from its copyright monopoly. ${ }^{183}$ The court explained that the revenues Perfect 10 could enjoy from the paid downloading of cell phone images could not "supersede" the public benefit arising from Google's search engine technology. ${ }^{184}$

This narrower construction of market harm continues to ground fair use in the notion of necessity. In Kelly, for example, the use of the entire copyrighted image was excused because it was deemed nec-

\footnotetext{
178 Kelly v. Arriba Soft Corp., 336 F.3d 811 (9th Cir. 2003).

179 Perfect 10, Inc. v. Amazon.com, Inc., 508 F.3d 1146 (9th Cir. 2007).

180 See id. at 1168; Kelly, 336 F.3d at 822.

181 Perfect 10, 508 F. 3d at 1168.
}

182 See Conversation with Jay Dougherty, supra note 174; see also, e.g., Salinger v. Colting, 641 F. Supp. 2d 250, 268 (S.D.N.Y. 2009), vacated on other grounds, 607 F.3d 68 (2d Cir. 2010). 183 See Perfect 10, 508 F.3d at 1168 (finding that "in light of the purpose of copyright" the "significant benefit" Google's transformative use provided to the public outweighed "potential harm" to an "unproven" market).

184 Id. at 1167-68; see Anthony Falzone, The Two Faces of Perfect 10 v. Google, Center FOR INTERNET \& SOC'y, StAN. L. SCH. (May 16, 2007, 1:57 PM), http://cyberlaw.stanford.edu/ node/5409 (characterizing the Perfect 10 decision as holding that "search engine technology provides an astoundingly valuable public benefit, which should not be jeopardized just because it might be used in a way that could affect somebody's sales"). 
essary to the proper functioning of the search engine database, which required full reproduction of the copyrighted image for recognition purposes. ${ }^{185}$ Similarly, in Bill Graham Archives v. Dorling Kindersley, $L t d .{ }^{186}$ the Second Circuit found fair use in the unauthorized reproduction of several concert posters for a coffee table book documenting the thirty-year history of the Grateful Dead. ${ }^{187}$ In the court's eyes, the use was transpurposive because, rather than seeking to "exploit the images' expressive value for commercial gain," the defendant was using them to help detail the band's biography and timeline. ${ }^{188}$ Accordingly, despite the plaintiff's claim that an established licensing market existed for reproductions of its concert posters, the court found no market harm. ${ }^{189}$ The court reasoned that "copying the entirety of a work is sometimes necessary to make a fair use of the image." 190

Thus, in a limited number of cases that implicate First Amendment rights-those involving parodies and transpurposive usescourts have found fair use. In a broad array of cases, however, including those involving clear acts of artistic expression such as satire, commentary, and criticism, courts frequently rely on broad definitions of commerciality and market harm to reject fair use defenses. In such cases, courts have placed core expressive speech that utilizes the copyrighted works of others at a decided disadvantage in the fair use test. For example, in Bill Graham Archives, the court noted that the defendant's activities were actually more likely to be fair use "because the reduced images have such minimal expressive impact." 191 In other words, if the use is more expressive, it is more likely to compete with the market for the original work and, therefore, it is ironically less likely to constitute fair use. Courts thus apply a double standard to the analysis of transexpressive uses on the one hand, and transpurposive uses on the other hand, even though both vindicate free speech interests. Overall, although the fair use test is supposed to incorporate First Amendment values, ${ }^{192}$ its current incarnation, particularly its

185 See Kelly, 336 F.3d at 821.

186 Bill Graham Archives v. Dorling Kindersley Ltd., 448 F.3d 605 (2d Cir. 2006).

187 See id. at $607,615$.

188 ld. at 612.

189 See id. at 614 (citing Am. Geophysical Union v. Texaco, Inc., 60 F.3d 913, 930 (2d Cir. 1994)).

190 Id. at 613.

191 Id. at 614 n.5.

192 See Eldred v. Ashcroft, 537 U.S. 186, 219-20 (2003). 
focus on necessity and its generous interpretations of commerciality and market harm, appears to privilege copyright over free speech.

\section{B. The Right of Publicity and the First Amendment}

The treatment of expressive rights under the right of publicity differs markedly from that of copyright law. "The right of publicity [is] defined as [an individual's] right to the exclusive [commercial] use of his or her name and likeness." 193 Although most judicial and statutory language stresses the right's availability to all citizens, ${ }^{194}$ in reality, this particular intellectual property construct is exercised predominantly by celebrities. ${ }^{195}$ Famous actors and actresses, athletes, and musicians use the right of publicity to stop outsiders from profiting off of their personae without their permission. ${ }^{196}$ The right's existence is justified in various ways, from utilitarian principles-such protection is needed to incentivize the creation of attractive celebrity personae ${ }^{197}$ - to natural rights - one's persona is so unique and personal that control of its use should reside only in the individual. ${ }^{198}$ Yet, because celebrities, particularly in the modern era, are central to common discourse and self-identification, these justifications have to be balanced against the public's desire to rework celebrity for its own expressive purposes. ${ }^{199}$

193 Toffoloni v. LFP Publ'g Grp., LLC, 572 F.3d 1201, 1205 (11th Cir. 2009) (second alteration in original) (internal quotation marks omitted).

194 See, e.g., Nev. Rev. STAT. \$ 597.790 (2010); Fanelle v. Lojack Corp., No. CIV.A 994292, 2000 WL 1801270, at *11 (E.D. Pa. Dec. 7, 2000) ("I am convinced that the right of publicity resides in every person, not just famous and infamous individuals.").

195 See K.J. Greene, Intellectual Property Expansion: The Good, the Bad, and the Right of

Publicity, 11 Chap. L. Rev. 521, 536-38 (2008).

196 See infra notes 427-30 and accompanying text.

197 See, e.g., Zacchini v. Scripps-Howard Broad. Co., 433 U.S. 562, 576 (1977); Matthews v. Wozencraft, 15 F.3d 432, 437 (5th Cir. 1994).

198 See Lugosi v. Universal Pictures, 603 P.2d 425, 438 (Cal. 1979) (Bird, C.J., dissenting); Diane Leenheer Zimmerman, Who Put the Right in the Right of Publicity?, 9 DEPAuL-LCA J. ARt \& ENT. L. 35, 80 (1998) ("I realize that, when all else is said and done, the reason that publicity rights have such a broad and loyal following is rooted in an intuition about fairness, a sense of the potential for a form of distributive injustice if celebrities cannot demand control over and payment for uses of their attributes.").

199 See generally Michael Madow, Private Ownership of Public Image: Popular Culture and Publicity Rights, 81 CALIF. L. REv. 125, 146-47 (1993). Although there are celebrity fans of all ages, in today's culture the use of celebrity images is particularly important for adolescent identity development. Psychologists have identified secondary attachment to celebrities as an important transition point from parental authority to more autonomous self-definition. See David C. Giles \& John Maltby, The Role of Media Figures in Adolescent Development: Relations Between Autonomy, Attachment, and Interest in Celebrities, 36 Personalrty \& Individual DifferENCEs 813, 814-15 (2004); A.L. Greene \& Carolyn Adams-Price, Adolescents' Secondary Attachments to Celebrity Figures, 23 Sex Roles 335, 336 (1990). 


\section{Invoking the First Amendment}

Early right of publicity decisions often gave little credence to First Amendment defenses. For example, in Estate of Presley v. Rus$s e n,{ }^{200}$ the court determined that an Elvis tribute act infringed the right of publicity because the impersonator's "show serves primarily to commercially exploit the likeness of Elvis Presley without contributing anything of substantial value to society." 201 While evaluating the liability of a television station for broadcasting a human cannonball act without the performer's permission, the Supreme Court said "we are quite sure that the First and Fourteenth Amendments do not immunize the media when they broadcast a performer's entire act without his consent." ${ }^{202}$ When an advertiser contended that it featured a robot in a wig, gown, and jewelry standing next to a letter board in a print advertisement to parody game show hostess Vanna White, the Ninth Circuit dispatched the argument quickly. ${ }^{203}$ Rather than being a parody, this was a "true advertisement run for the purpose of selling Samsung VCRs," and, as such, did not enjoy First Amendment protection. ${ }^{204}$

Today, in contrast to the practice just a couple of decades earlier, courts adjudicating right of publicity claims are far more willing to invoke the First Amendment. Unlike copyright and trademark law, which attempt to address free speech concerns within their own bodies of doctrine, modern right of publicity jurisprudence often explicitly considers whether a verdict for the plaintiff would violate the Free Speech Clause. ${ }^{205}$

In several recent leading cases, courts have not hesitated to resolve right of publicity cases explicitly on First Amendment grounds. In Winter v. DC Comics, for example, the California Supreme Court

200 Estate of Presley v. Russen, 513 F. Supp. 1339 (D.N.J. 1981).

201 Id. at 1359.

202 Zacchini v. Scripps-Howard Broad. Co., 433 U.S. 562, 563-64, 575 (1977).

203 See White v. Samsung Elecs. Am., Inc., 971 F.2d 1395, 1396, 1401 (9th Cir. 1992).

204 See id. at 1401. Joe Bauer describes White as "[p]erhaps the leading example of a failure to recognize, much less accommodate, First Amendment interests." Joseph P. Bauer, Copyright and the First Amendment: Comrades, Combatants, or Uneasy Allies?, 67 WASH. \& LeE L. Rev. 831, 912 n.403 (2010).

205 See, e.g., Downing v. Abercrombie \& Fitch, 265 F.3d 994, 1001-03 (9th Cir. 2001); Aronson v. Dog Eat Dog Films, Inc., 738 F. Supp. 2d 1104, 1113-14 (W.D. Wash. 2010); Yeager v. Cingular Wireless LLC, 627 F. Supp. 2d 1170, 1174-75 (E.D. Cal. 2008); see also 2 J. Thomas McCarthy, The Rights of Publictry and Privacy \$ 8:94 (2d ed. 2009) ("Unlike trademark and copyright law, the right of publicity does not have a built-in rule to accommodate parody use of human identity... [ [P]arody uses must find their safe harbor in the free speech principles of the First Amendment."). 
avoided any specific consideration of the celebrity plaintiffs' right of publicity claim, choosing to base its decision solely on the First Amendment. ${ }^{206}$ The Tenth Circuit, after examining baseball players' right of publicity claims, explained that it had to consider whether a manufacturer of baseball cards "has a countervailing First Amendment right to publish the cards." 207 In another case involving unauthorized use of baseball player identities, the Eighth Circuit went out of its way to interrogate the First Amendment defense raised by an organizer of fantasy baseball leagues rather than decide the case on the alternative grounds of federal preemption of state publicity law.208 In a case involving a painter's unauthorized representation of Tiger Woods, the Sixth Circuit spent a large portion of its analysis on the First Amendment, explaining that even regulation of commercial speech implicated important constitutional issues that had to be addressed. ${ }^{209}$ And when Paris Hilton sued Hailmark for usurping her right of publicity with the unauthorized use of a super-sized photograph of her head superimposed on a cartoon waitress's body, the Ninth Circuit did not hesitate to allow Hallmark to apply California's anti-SLAPP statute ${ }^{210}$ as a defensive measure. ${ }^{211}$ All told, while courts are reluctant to invoke the "ultimate heavy weapon of judicial interpretation"212 - the First Amendment-in many other contexts, they have shown little compunction about doing so in right of publicity cases. $^{213}$

\footnotetext{
206 See Winter v. DC Comics, 69 P.3d 473, 479 (Cal. 2003).

207 Cardtoons, L.C. v. Major League Baseball Players Ass'n, 95 F.3d 959, 968 (10th Cir. 1996).

208 C.B.C. Distribution \& Mktg., Inc. v. Major League Baseball Advanced Media, L.P., 505 F.3d 818, 823-24 (8th Cir. 2007).

209 ETW Corp. v. Jireh Publ'g, Inc., 332 F.3d 915, 918, 924-25, 937-38 (6th Cir. 2003).

210 SLAPP stands for Strategic Lawsuits Against Public Participation. Hilton v. Hallmark Cards, 599 F.3d 894, 902 (9th Cir. 2010). California's anti-SLAPP statute, like those of many other states, provides for the use of a special motion to strike that grants protections, including the possibility of early adjudication and the automatic award of attorneys' fees, to defendants facing suits stemming from "conduct in furtherance of the exercise of the constitutional right of ... speech in connection with a public issue or an issue of public interest." CAL. Civ. Proc. CODE $\$ 425.16$ (a)-(c), (e)(4) (West 2012); see also Hilton, 599 F.3d at 902.

211 See Hilton, 599 F.3d at 899, 904-08. Although the Ninth Circuit ultimately allowed the case to go forward on the grounds that Hallmark could not prove, as a matter of law, that its use was transformative, the court did conclude that "Hallmark has shown that Hilton's suit for misappropriation of publicity arises from conduct in furtherance of the exercise of the constitutional right of ... free speech." Id. at 908, 910 (internal quotation marks omitted).

212 William McGeveran, Rethinking Trademark Fair Use, 94 IowA L. Rev. 49, 98 (2008); see also supra Part I.A.1 (discussing judicial reluctance to discuss the First Amendment in copyright cases).

213 Interestingly, a court may have good reasons for avoiding direct evaluation of a First
} 


\section{Replacing Necessity with a Broad Conception of Transformation}

Another dramatic change in the right of publicity/First Amendment interface stems from the introduction of a broad conception of transformation. The central role of transformative use in right of publicity doctrine is evident in the displacement of necessity from the free expression calculus and the expansive reading the courts give to the concept of "newsworthiness."

\section{a. The Primacy of Transformation}

In some earlier cases, courts questioned whether the defendant's use of a celebrity persona was necessary to express the defendant's point. ${ }^{214}$ Courts carved out liability exemptions for "matters of news, history, biography, and other factual subjects of public interest" due to "necessary references to the names, portraits, identities, or histories of living persons."215 For example, in a 1953 case involving the unauthorized use of a radio announcer's name by a broadcasting company, the Supreme Court of Alabama opined on the limitations of the right of publicity (then stylized as a right of privacy). ${ }^{216}$ As the court noted, "[a] public character does relinquish a part of his right of privacy. But

Amendment challenge to the right of publicity. A decision based on common law understandings remains open to future alterations, both judicial and legislative, but a decision anchored in the First Amendment is much more difficult to work around. See Pierre N. Leval, Trademark: Champion of Free Speech, 27 Colum. J.L. \& ARTs 187, 209 (2004); Lisa P. Ramsey, Increasing First Amendment Scrutiny of Trademark Law, 61 SMU L. REV. 381, 452 (2008); see also Cass R. Sunstein, Interpreting Statutes in the Regulatory State, 103 HARV. L. REV. 405, 468 (1989). Not every dispute involving the right of publicity requires constitutional analysis, and injecting the First Amendment into the litigation may consume judicial resources unnecessarily. $C f$. Ramsey, supra, at 452 (discussing disadvantages of First Amendment analysis in trademark cases). For these reasons and others, several commentators have suggested internal refinements to the right of publicity to address expressive interests and thereby avoid constitutional confrontations. See Randall T.E. Coyne, Toward a Modified Fair Use Defense in Right of Publicity Cases, 29 WM. \& MARY L. REv. 781, 817 (1988) (arguing that courts should create a fair use defense for right of publicity cases modeled on 17 U.S.C. $\$ 107$ (2006)); Peter L. Felcher \& Edward L. Rubin, Privacy, Publicity, and the Portrayal of Real People by the Media, 88 YALE L.J. 1577, 1579 (1979); Pamela Samuelson, Reviving Zacchini: Analyzing First Amendment Defenses in Right of Publicity and Copyright Cases, 57 TuL. L. REv. 836, 837 (1983). But see 2 McCARTHY, supra note 205, at $\S 8: 39$ (arguing that incorporating free speech principles into the right of publicity cause of action would not make the law any clearer or easier to apply than direct application of the First Amendment).

214 See, e.g., Spahn v. Julian Messner, Inc., 260 N.Y.S.2d 451, 453 (N.Y. App. Div. 1965).

215 See Hicks v. Casablanca Records, 464 F. Supp. 426, 430 (S.D.N.Y. 1978).

216 Birmingham Broad. Co. v. Bell, 68 So. 2d 314, 314-15 (Ala. 1953). 
such a waiver is limited to that which may be legitimately necessary and proper for public information." 217

Today, however, any argument that a defendant's First Amendment rights should yield to the right of publicity when alternative means are available for communicating the defendant's message is highly disfavored-in dramatic contraposition to copyright law. For example, the Tenth Circuit rejected an argument that a creator of baseball cards that poked fun at celebrity athlete personae should be required to either use only "generic" players or to criticize individual players in a noncommercial format like a book or newspaper editorial."18 Finding that the "no adequate alternative avenues test does not sufficiently accommodate the public's interest in free expression," the court held in favor of the defendant based on the defendant's First Amendment defense. ${ }^{219}$ The court explained that an examination of expressive alternatives did not adequately protect the defendant's right of free expression because forbidding use of particular celebrities or particular expressive formats also ran a "substantial risk of suppressing ideas."220 Similarly, in the Tiger Woods case, the Sixth Circuit addressed whether a painting depicting three views of Woods in different poses titled "The Masters of Augusta" violated Woods's right of publicity. ${ }^{221}$ The court did not consider whether the artist needed to feature three separate representations of Woods to make his expressive point. Instead, in deciding that the First Amendment should trump Woods's publicity rights, the court emphasized the important semiotic freight provided by celebrities in modern culture and the painter's artistic skill.222

Rather than asking whether the defendant needed to invoke the celebrity, courts now examine the transformativeness of the defendant's expressive activity as an independent and absolute defense to a prima facie violation of the right of publicity. In the landmark case of Comedy III Productions v. Gary Saderup, Inc., 223 the California Supreme Court identified a new standard for First Amendment scrutiny

217 Id. at 319 (emphasis added) (citations omitted). As previously noted, this rhetoric of "necessity" continues to dominate copyright's fair use defense, especially in the way federal courts have developed the parody/satire distinction. See supra notes 85-109 and accompanying text.

218 Cardtoons, L.C. v. Major League Baseball Players Ass'n, 95 F.3d 959, 971 (10th Cir. 1996).

219 Id. at 971-76 (internal quotation marks omitted).

220 Id. at 971.

221 See ETW Corp. v. Jireh Publ'g, Inc., 332 F.3d 915, 918 (6th Cir. 2003).

222 See id. at 937-38.

223 Comedy III Prods., Inc. v. Gary Saderup, Inc., 21 P.3d 797 (Cal. 2001). 
of right of publicity cases. In determining whether a downstream work involving unauthorized use of a celebrity persona could invoke the First Amendment, the court announced that the proper "inquiry is whether the celebrity likeness is one of the raw materials from which an original work is synthesized, or whether the depiction or imitation of the celebrity is the very sum and substance of the work in question." 224

Accordingly, in right of publicity cases, courts have increasingly rejected the rigid line that copyright courts have drawn between parody, on one hand, and satires and other forms of criticism, on the other hand. As discussed previously, courts have elevated parodies above all other transformative uses when considering copyright's fair use defense because parodies must conjure up enough of an original work to enable audiences to recognize that which is being mocked. ${ }^{225}$ As a result, (unauthorized) use of an original is said to be necessary (and therefore excused) for parodic, but not satirical or other critical, purposes. ${ }^{226}$ In Comedy III, however, the court explicitly broke with copyright jurisprudence and held that the reach of the transformative use defense in right of publicity cases extends much further than copyright's conception of transformative use. ${ }^{227}$ After all, the court reasoned, all forms of transformative use, not just parodies, demand First Amendment protection: "[T]ransformative elements or creative contributions that require First Amendment protection are not confined to parody and can take many forms, from factual reporting to fictionalized portrayal, from heavy-handed lampooning to subtle social criticism." 228 Necessity therefore plays no role in the right of publicity's version of fair use. "Because celebrities take on public meaning, the appropriation of their likenesses may have important uses in uninhibited debate on public issues, particularly debates about culture and values,"229 regardless of whether one must invoke them to make one's point.

Courts applying Comedy III have hewed to its broad construction of transformativeness. ${ }^{230}$ In one recent case, Kierin Kirby, the lead singer of the band Deee-Lite, sued Sega for manufacturing a vide-

224 See id. at 800-01, 809 (internal quotation marks omitted).

225 See supra Part I.A.2.a.

226 See supra Part I.A.2.a.

227 See Comedy III, 21 P.3d at 809.

228 Id. (citations omitted).

229 Id. at 803.

230 See, e.g., ETW Corp. v. Jireh Publ'g, Inc., 332 F.3d 915, 936 (6th Cir. 2003); Hoepker v. Kruger, 200 F. Supp. 2d 340, 350 (S.D.N.Y. 2002). 
ogame featuring a main character that resembled her. ${ }^{231}$ The video game character's facial features, clothing, hairstyle, and use of certain catch phrases bore a striking resemblance to Kirby. ${ }^{232}$ Kirby alleged violations of her common law and statutory rights of publicity while Sega, in response, asserted a First Amendment defense. ${ }^{233}$ The California Court of Appeal stated that the appropriate test to evaluate this defense was whether Sega "adds something new, with a further purpose or different character, altering the first with new expression, meaning, or message." 234 Even though Sega approached Kirby prior to the game's release to endorse the game, the court did not indicate that this information was relevant in determining the reach of the First Amendment. ${ }^{235}$ Consider how dramatically this position contrasts to copyright jurisprudence or White v. Samsung Electronics America, Inc. ${ }^{236}$ where the Ninth Circuit brusquely rejected a First Amendment defense and noted that Samsung had paid other celebrities besides Vanna White in return for authorization to use their likenesses in its advertising campaign. ${ }^{237}$

\section{b. Protecting Newsworthy Uses}

On a related note, courts have created a "newsworthiness" defense in right of publicity cases. ${ }^{238}$ In contrast to copyright law's willingness to second guess reporters' utilizations of copyrighted works, ${ }^{239}$ the newsworthy defense in right of publicity cases carves out a broad zone of immunity for secondary uses of celebrity personae without requiring judicial investigation into whether such uses are necessary to a journalist's expressive project. ${ }^{240}$ Although courts have long noted the need to weigh the public interest in considering claims of publicity rights infringement directed at reporting services, ${ }^{241}$ the newsworthi-

231 See Kirby v. Sega of Am., Inc., 50 Cal. Rptr. 3d 607, 609-11, 613 (Cal. Ct. App. 2006).

232 See id. at 613.

233 See id. at 612-14.

234 Id. at 615 (quoting Comedy III, 21 P.3d at 808) (internal quotation marks omitted).

235 See id. at $610,614-18$.

236 White v. Samsung Elecs. Am., Inc, 971 F.2d 1395 (9th Cir. 1992).

237 See id. at 1401; id. at 1407 (Alarcon, J., concurring in part and dissenting in part) (noting that "[t]he majority gives Samsung's First Amendment defense short shrift").

238 See, e.g., Toffoloni v. LFP Publ'g Grp., LLC, 572 F.3d 1201, 1208 \& n.2 (11th Cir. 2009); Titan Sports, Inc. v. Comics World Corp., 870 F.2d 85, 87 (2d. Cir. 1989). In addition to judicially created protections for newsworthiness in common law right of publicity regimes, some right of publicity statutes contain exceptions for news reporting. See, e.g., CaL. CIv. Code $\$ 3344$ (d) (West 2012); IND. CODE $\S 32-36-1-1$ (b)-(c) (2012).

239 See, e.g., Harper \& Row, Publishers, Inc. v. Nation Enters., 471 U.S. 539, 557 (1985).

240 See, e.g., Nichols v. Moore, 334 F. Supp. 2d 944, 956 (E.D. Mich. 2004).

241 See, e.g., Chaplin v. Nat'l Broad. Co., 15 F.R.D. 134, 138 (S.D.N.Y. 1953). 
ness exception has gained traction in recent years. Under the exception, use of celebrity personae in media presentations deemed to be "news" is exempted from liability for infringement of the right of publicity. ${ }^{242}$ This exception has been generously defined by some courts and has the potential to serve as a great counterweight to the right, especially in a world where widespread blogging and virtually costless digital distribution have made it relatively easy for anyone to claim journalistic bona fides. ${ }^{243}$ To fit within the exception, the use at issue must involve matters of public concern. As discussed by one court:

[T] he public is interested in and constitutionally entitled to know about things, people, and events that affect it. For that reason, we cannot limit the term "public affairs" to topics that might be covered on public television or public radio. To do so would be to jeopardize society's right to know, because publishers and broadcasters could be sued for use of name and likeness in documentaries on subjects that do not relate to politics or public policy, and may not even be important, but are of interest. ${ }^{244}$

Given this reasoning, the newsworthiness exception covers more than just strictly political speech. Indeed, courts are reluctant to deem any discussion of celebrity insufficiently important to public discourse. Fashion, ${ }^{245}$ celebrity romances, ${ }^{246}$ celebrity weddings, ${ }^{247}$ baseball statistics, ${ }^{248}$ and the habits of top surfers ${ }^{249}$ have all been deemed suffi-

242 See, e.g., Lerman v. Flynt Distrib. Co., 745 F.2d 123, 131-32 (2d Cir. 1984).

243 See id. at 139 (stating that "[c]ourts are, and should be, reluctant to attempt to define newsworthiness"); Armstrong v. Eagle Rock Entm't, Inc., 655 F. Supp. 2d 779, 786 (E.D. Mich. 2009) (describing the privilege as extending to "include all types of factual, educational, and historical data, or even entertainment and amusement, concerning interesting phases of human activity in general'" (quoting Nichols, 334 F. Supp. 2d at 944, 956)); Nichols, 334 F. Supp. 2d at 956 ("The scope of the subject matter which may be considered of 'public interest' or 'newsworthy' has been defined in the most liberal and far-reaching terms."). But see Hilton v. Hallmark Cards, 599 F.3d 894, 912 (9th Cir. 2010) (holding that, for the limited purpose of evaluating defendant's motion to strike plaintiff's right of publicity claim under California's anti-SLAPP statute, defendant could not invoke newsworthiness defense for publication of greeting card featuring plaintiff's image and catchphrase).

244 Dora v. Frontline Video, Inc., 18 Cal. Rptr. 2d 790, 794 (Cal. Ct. App. 1993).

245 See Hoffman v. Capital Cities/ABC, Inc., 255 F.3d 1180, 1185-86 (9th Cir. 2001) (altered photograph qualified as "editorial opinion").

246 See Ward v. Klein, 809 N.Y.S.2d 828, 830, 833 (N.Y. Sup. Ct. 2005); Eastwood v. Superior Court, 198 Cal. Rptr. 342, 344-45, 352 (Cal. Ct. App. 1983).

247 See Time Inc. v. Sand Creek Partners, L.P., 825 F. Supp. 210, 213 (S.D. Ind. 1993).

$248 \mathrm{See}$ C.B.C. Distribution \& Mktg., Inc. v. Major League Baseball Advanced Media, L.P., 505 F.3d 818, 823-24 (8th Cir. 2007) (recognizing "the public value of information about the game of baseball and its players"); Gionfriddo v. Major League Baseball, 114 Cal. Rptr. 2d 307, 410, 415 (Cal. Ct. App. 2001). 
ciently newsworthy for the defendant to avoid liability for infringing the subject's publicity rights. To satisfy the newsworthiness exception there must only be a "reasonable relationship" between the celebrity persona and the story's subject. ${ }^{250}$ Hence, if the connection between the persona and the defendant's news story is tenuous ${ }^{251}$ or if the news story has been knowingly fabricated, ${ }^{252}$ the defendant cannot take advantage of the newsworthiness exception. In sum, as currently conceptualized, there are few limits on the newsworthiness exception, making it a powerful weapon for those accused of publicity rights violations.

\section{Discounting Market-Based Harms}

Finally, counter to the trend in copyright law, market-based concerns now merit less consideration in the right of publicity's First Amendment jurisprudence. In the earlier history of the right, when courts chose not to recognize a First Amendment defense, they typically engaged in a definitional balancing test. ${ }^{253}$ Under this approach, some categories of speech are immunized from liability, but other categories receive lesser or no First Amendment scrutiny. ${ }^{254}$ For example, once speech is placed in the category of "obscenity," it forfeits First Amendment protection. ${ }^{255}$ Similarly, relying on a distinction between commercial and noncommercial speech, courts held that every use of a celebrity persona deemed "commercial" must yield to the plaintiff's property right. The crucial determination was whether the defendant's activity could be described as commercial, and courts chose to define the term broadly. For example, the Ninth Circuit explained that the obvious profit motive behind Samsung's advertisement evoking Vanna White eliminated the need for careful First Amendment analysis. ${ }^{256}$ Likewise, because the defendant's "primary purpose . . . is to appropriate the commercial value of the likeness of Elvis Presley," the Elvis impersonator could be enjoined from further

249 See Chapman v. Journal Concepts, Inc., 528 F. Supp. 2d 1081, 1084-85, 1096 (D. Haw. 2007); Dora, 18 Cal. Rptr. 2d at 794-95.

250 See 2 MCCARTHY, supra note 205, \& 8:57.

251 See, e.g., Downing v. Abercrombie \& Fitch, 265 F.3d 994, 1002 (9th Cir. 2001); Nieves v. Home Box Office, Inc., 817 N.Y.S.2d 227, 227 (N.Y. App. Div. 2006).

252 See, e.g., Eastwood v. Nat'l Enquirer, Inc., 123 F.3d 1249, 1252, 1255-56 (9th Cir. 1997).

253 See, e.g., Estate of Presley v. Russen, 513 F. Supp. 1339, 1357-58 (D.N.J. 1981).

254 See id. at 1359 (finding that while entertainment in general receives full First Amendment protection, "entertainment that is merely a copy or imitation" does not).

255 See Roth v. United States, 354 U.S. 476, 484-85 (1957).

256 See White v. Samsung Elecs. Am., Inc., 971 F.2d 1395, 1401 \& n.3 (9th Cir. 1992). 
use of Elvis's persona. ${ }^{257}$ On the other hand, when defendants deployed celebrity names and images in media like books or films, courts were willing to deem those uses "noncommercial" and, hence, immunized from infringement liability. ${ }^{258}$

Modern courts have realized, however, that a simple definitional balancing test dependent on the commercial/noncommercial distinction is inadequate to safeguard free speech interests in celebrity personae. Again, the California Supreme Court has led the way in this regard. Unlike the fair use defense in copyright law, market harm and commercial motivation play no role in that court's application of the transformative use defense under the right of publicity. Two years after Comedy III, the court made this point explicit by holding that an analysis of the effect of an unauthorized use upon the potential market for the plaintiff's persona has no place in right of publicity jurisprudence. ${ }^{259}$ In Winter $v$. DC Comics, the court explained that "even if the work's marketability and economic value derive primarily from the fame of the celebrity depicted, the work may still be transformative and entitled to First Amendment protection."260 Hence, the Winter court set aside the lower court's finding that the defendant comic book manufacturer was trading on the plaintiffs' likenesses to generate interest and increase sales, holding that such facts were "irrelevant." 261 In a remarkable divergence from copyright's fair use defense, the court concluded that "[t]he question is whether the work is transformative, not how it is marketed." 262

Other courts have followed the same path. For example, the defendant's addition of "numerous independent creative elements" defeated a right of publicity suit from the members of the rock band The Romantics against a video game manufacturer that used the band's

257 Estate of Presley, 513 F. Supp. at 1360-61; see also Seale v. Gramercy Pictures, 949 F. Supp. 331, 337 (E.D. Pa. 1996) ("[I]n addressing right of publicity claims, courts have been mindful that the First Amendment provides greater protection to works of artistic expression such as movies, plays, books, and songs, than it provides to pure 'commercial' speech.").

258 See, e.g., Hoffman v. Capital Cities/ABC, Inc., 255 F.3d 1180, 1185-86 (9th Cir. 2001) (relying on commercial/noncommercial distinction to determine that a magazine's unauthorized use of Dustin Hoffman's photograph did not violate his right of publicity); Frosch v. Grosset \& Dunlap, Inc., 427 N.Y.S.2d 828, 828 (N.Y. App. Div. 1980) (presuming Norman Mailer's biography of Marilyn Monroe was noncommercial because of its literary nature).

259 See Winter v. DC Comics, 69 P.3d 473, 479 (Cal. 2003).

260 Id. at 478.

261 See id. at 479.

$262 I d$. 
name and most popular song without its permission. ${ }^{263}$ Similarly, the Sixth Circuit held that the presence of "substantial transformative elements" in a painting of Tiger Woods meant that the work was "entitled to the full protection of the First Amendment."264 In evaluating whether Penthouse magazine's publication of intimate photographs of Pamela Anderson and Tommy Lee infringed their rights, the judge concluded that the photographs were a "legitimate subject" and their role in attracting purchasers of the magazine was irrelevant. ${ }^{265} \mathrm{An}$ other court explained that it was irrelevant under the newsworthiness exception that the San Jose Mercury News not only appropriated quarterback Joe Montana's name and likeness for its front page, but also used his name and the same likeness to sell posters commemorating Montana's fourth Super Bowl victory. ${ }^{266}$ What is significant about these decisions is that the courts no longer focused on whether the defendant's appropriation stemmed from a desire to profit off of the plaintiffs' celebrity. Arguably, all of these defendants appropriated famous names and faces for just that reason. After all, it was Tiger Woods's contextualized image, rather than those of long forgotten golfing greats, that gave value to the homage painting "Masters of Augusta."267 Consumers paid money to put posters of Joe Montana, not Joe Blow, up in their bedrooms. ${ }^{268}$ Readers would have little interest if the intimate photographs published by Penthouse featured Louie, rather than Pamela, Anderson. ${ }^{269}$ Yet all of the alleged infringers in these suits still managed to assert successful First Amendment defenses. These outcomes were largely charted by a critical switch in a component of the First Amendment analysis: while courts of yore would evaluate the commerciality of a defendant's activity, modern courts evaluate a defendant's contribution to free expression. ${ }^{270}$

This dramatic shift in analytical emphasis has not come without its critics, who decry the indeterminacy of these changes in right of publicity law. Indeed, relying primarily on the First Amendment to

263 See Romantics v. Activision Publ'g, Inc., 574 F. Supp. 2d 758, 762, 766 \& n.3 (E.D. Mich. 2008).

264 ETW Corp. v. Jireh Publ'g, Inc., 332 F.3d 915, 938 (6th Cir. 2003).

265 Lee v. Penthouse Int'l, Ltd., No. CV 96-7069 SVW (JGx), 1997 U.S. Dist. LEXIS 23893, at *15 (C.D. Cal. Mar. 20, 1997).

266 See Montana v. San Jose Mercury News, Inc., 40 Cal. Rptr. 2d 639, 642, 643 \& n.2 (Cal.

Ct. App. 1995).

267 See ETW Corp., 332 F.3d at 918.

268 See Montana, 40 Cal. Rptr. 2d at 794.

269 See Lee, 1997 U.S. Dist. LEXIS 23893, at*5.

270 Compare White v. Samsung Elecs. Am., Inc., 971 F.2d 1395, 1398 (9th Cir. 1992), with Cardtoons, L.C. v. Major League Baseball Players Ass'n, 95 F.3d 959, 972-73 (10th Cir. 1996) 
negotiate the boundary between publicity rights and free expression may not provide much clarity for litigants. ${ }^{271}$ Whether or not the defendant's use of the celebrity persona bears a sufficient connection to the defendant's overall work to qualify for the newsworthiness exception may prove difficult to predict in advance. ${ }^{272}$ Likewise, the transformation test introduced in Comedy III is incredibly broad and subject to multiple interpretations. As one commentator describes the test's application, "a bit of tweaking here and there to the image or likeness or the name may allow an 'unauthorized' artist to capitalize on that person." ${ }^{273}$ Under previous right of publicity jurisprudence, judges had some leeway in determining whether a use was commercial or not. ${ }^{274}$ But an analysis of whether a use is "newsworthy" or adds "significant creative elements" may dramatically enlarge judicial discretion. ${ }^{275}$

Scholars have also explored whether the transformation test and newsworthiness defense are principled ways to apply the First Amendment in these cases. ${ }^{276}$ While these scholars may have legitimate concerns, the purpose of this Article is to focus on how the introduction of these changes to right of publicity law resulted in the heightened importance of free expression considerations in the infringement calculus. By and large, judges have used these doctrinal innovations to find in favor of defendants in right of publicity cases. ${ }^{277}$ What remains unsolved, however, is the question discussed in Part II: why did judges feel a need to promote free expression in the celebrity

271 See Gloria Franke, Note, The Right of Publicity vs. the First Amendment: Will One Test Ever Capture the Starring Role?, 79 S. CAL. L. Rev. 945, 968-69 (2006) (discussing arguments in favor and against creation of a fair use standard to accommodate First Amendment interests in the publicity rights context); $c f$. Ramsey, supra note 213, at 452 (discussing same argument in context of trademark law).

272 See Richard T. Karcher, Tort Law and Journalism Ethics, 40 LoY. U. CHI. L.J. 781, 795 (2009) (describing inconsistencies in definitions and holdings surrounding newsworthiness defenses); Andrew J. McClurg, Kiss and Tell: Protecting Intimate Relationship Privacy Through Implied Contracts of Confidentiality, 74 U. CIN. L. REV. 887, 903 (2006) (describing the newsworthiness standard as "amorphous").

273 Eric Farber, U-La-La, What's Happened to Our California Right of Publicity?, 11 CHAP. L. Rev. 449, 460 (2008).

274 See, e.g., Estate of Presley v. Russen, 513 F. Supp. 1339, 1358 (D.N.J. 1981) (considering whether an Elvis impersonator's show constituted a "valuable contribution of information or culture" but concluding that the show "serves primarily to commercially exploit the likeness of Elvis Presley").

275 See, e.g., Comedy III Prods., Inc. v. Gary Saderup, Inc., 21 P.3d 797, 810 (Cal. 2001).

276 See Diane Leenheer Zimmerman, Money as a Thumb on the Constitutional Scale: Weighing Speech Against Publicity Rights, 50 B.C. L. Rev. 1503, 1512 (2009).

277 See, e.g., Cardtoons, L.C. v. Major League Baseball Players Ass'n, 95 F.3d 959, 976 (10th Cir. 1996); Hart v. Electronic Arts, Inc., 808 F. Supp. 2d 757, 783-86 (D.N.J. 2011) 
rights context, but not in the context of the unauthorized use of the writings, paintings, and other artistic works protected under copyright?

\section{Trademark and the First Amendment}

While not subject to the same level of heightened First Amendment scrutiny applied to publicity rights, trademark rights are checked by more expansive speech-related defenses than copyrights. Trademark law has traditionally prevented uses of marks that are likely to cause confusion among the consuming public. ${ }^{278}$ To assess this likelihood, courts apply a multifactor test, which examines such factors as the strength of the plaintiff's mark, the degree of similarity between the plaintiff's and defendant's marks, the similarity of the products sold by the plaintiff and the defendant, and the sophistication of likely consumers. ${ }^{279}$ The promotion of economic efficiency serves as the dominant rationale for trademark rights and is achieved by minimizing the likelihood of consumer confusion in the marketplace. ${ }^{280}$ When consumers can rely on the source-indicating qualities of brand names, they can quickly engage in beneficial transactions instead of painstakingly researching each individual product. ${ }^{281}$ Consumer protection may sometimes need to be leavened, however, in order to allow trademarks to be used as resources for social communication. In American culture, the language of brands has become central to representing the self and critical to forming bonds with others. ${ }^{282}$ Hence, as with the right of publicity, the law must try to reconcile trademark rights with rights to free expression.

\section{Addressing the First Amendment}

Unlike the right of publicity and its frequent invocation of the First Amendment, trademark law is more like copyright in its resort to internal mechanisms to address issues of free expression. ${ }^{283}$ In the

278 See, e.g., Karl Storz Endoscopy-Am., Inc. v. Surgical Techs., Inc., 285 F.3d 848, 853-54 (9th Cir. 2002).

279 See, e.g., Playtex Prods., Inc. v. Georgia-Pacific Corp., 390 F.3d 158, 162 (2d Cir. 2004).

280 See Mark Bartholomew, Making a Mark in the Internet Economy: A Trademark Analysis of Search Engine Advertising, 58 OKLA. L. Rev. 179, 195-96 (2005); Sonia K. Katyal, Trademark Intersectionality, 57 UCLA L. Rev. 1601, 1614-15 (2010).

281 See Bartholomew, supra note 280, at 195-96; Barton Beebe, The Semiotic Analysis of Trademark Law, 51 UCLA L. REv. 621, 623-24 (2004).

282 See Mark Bartholomew, Advertising and Social Identity, 58 BuFF. L. REv. 931, 941-42 (2010).

283 Although this Article focuses on actions for infringement, the trademark doctrine of scandalousness also manages to avoid constitutional review despite seeming to cry out for First 
past, courts held that the limitation of cognizable infringement claims to instances of likely confusion adequately addressed any First Amendment concerns. Put a different way, because courts rejected the existence of a First Amendment right to confuse consumers, no departure from the traditional likelihood of confusion analysis was needed to evaluate defenses based on the constitutional right to free expression. ${ }^{284}$ For example, in a case involving use of the trademarked term "Blue Book," the court quickly rejected a First Amendment defense because "substantial evidence was introduced at trial indicating that defendants' use of [plaintiffs'] ' $1-900-B L U-B O O K$ ' and ' $1-800$ BLUE-BOOK' designations is misleading in that it is likely to cause confusion among consumers." ${ }^{285} \mathrm{Or}$, in the parlance of traditional free speech jurisprudence, there is no First Amendment right to engage in misleading commercial speech. ${ }^{286}$

Modern courts are less prone to assume that infringing speech never triggers First Amendment concerns. In a few cases, courts explicitly invoke the First Amendment when they recognize a clash between infringing uses of another's trademark and free speech. ${ }^{287}$ In the vast majority of cases, however, courts attempt to address expres-

Amendment analysis. Under the scandalousness doctrine, a trademark that "[c]onsists of or comprises ... scandalous matter" is ineligible for trademark registration. 15 U.S.C $\$ 1052$ (a) (2006). Whether or not a mark is scandalous is ascertained from the standpoint of the general public. In re Mavety Media Grp. Ltd., 33 F.3d 1367, 1371 (Fed. Cir. 1994). Despite obviously regulating speech on the basis of its content, the scandalousness doctrine has not been successfully challenged under the First Amendment in any case. See Katyal, supra note 280, at 1690-98 (discussing the potential effects of $\S 1052$ (a) on speech).

284 See David M. Kelly \& Lynn M. Jordan, Twenty Years of Rogers v. Grimaldi: Balancing the Lanham Act with the First Amendment Rights of Creators of Artistic Works, 99 TRADEMARK REP. 1360, 1362 (2009).

285 Kelley Blue Book v. Car-Smarts, Inc., 802 F. Supp. 278, 291 (C.D. Cal. 1992); see also Coca-Cola Co. v. Gemini Rising, Inc., 346 F. Supp. 1183, 1192-93 (E.D.N.Y. 1972); Ramsey, supra note 213 , at $415 \&$ n.207 (listing other examples). This approach to unauthorized expressive uses occurred in the context of a shifting historical view of commercial speech and the First Amendment. Previously, commercial speech received little to no First Amendment protection. See, e.g., Valentine v. Chrestensen, 316 U.S. 52, 62 (1942) ("We are . . clear that the Constitution imposes no ... restraint on government as respects purely commercial advertising."). This is no longer the case, however. See, e.g., 44 Liquormart, Inc. v. Rhode Island, 517 U.S. 484, 522 (1996) (Thomas, J., concurring) (noting that there is no "philosophical or historical basis for asserting that 'commercial' speech is of 'lower value' than 'noncommercial' speech").

286 See Ramsey, supra note 213, at 415.

287 See, e.g., Univ. of Ala. Bd. of Trs. v. New Life Art, Inc., 683 F.3d 1266, 1276-79 (11th Cir. 2012); Lamparello v. Falwell, 420 F.3d 309, 313-14 (4th Cir. 2005); L.L. Bean, Inc. v. Drake Publishers, Inc., 811 F.2d 26, 30-34 (1st Cir. 1987); Charles Atlas, Ltd. v. DC Comics, Inc., 112 F. Supp. 2d 330, 337-39 (S.D.N.Y. 2000). 
sive concerns without resorting to a constitutional analysis. ${ }^{288}$ One typical approach involves ad hoc balancing. Courts will acknowledge that the defendant is using the plaintiff's mark in a socially valuable, expressive way and then apply that understanding to the likelihood of confusion test. One commentator describes this as "putting a discrete judicial finger on the scales in favor of the defendant." 289 This approach is frequently used when the defendant claims to merely parody the plaintiff's mark. For example, when a pet supply business sold toys with names like "Chewy Vuiton," the Fourth Circuit adjusted its typical analysis of trademark infringement, explaining that a parodic use "influences the way in which the [likelihood of confusion] factors are applied." 290 Similarly, in assessing whether a nightclub identifying itself as "The Velvet Elvis" infringed on the trademark of Elvis Presley Enterprises, the court first determined that the nightclub was engaging in a successful parody and then used the determination to tilt the scales in favor of the defendant in weighing the likelihood of confusion factors. ${ }^{291}$ The ad hoc balancing approach is also often found in cases involving political speech. Rather than explicitly invoking the First Amendment, courts have found in favor of politically active defendants simply by noting the expressive nature of the defendants' use and then construing the multipart likelihood of confusion factors in the defendants' favor. ${ }^{292}$

In addition to the ad hoc balancing approach, in recent years courts have developed two specific mechanisms for addressing free

288 See, e.g., Louis Vuitton Malletier S.A. v. Haute Diggity Dog, LLC, 507 F.3d 252, 261 (4th Cir. 2007).

$2896 \mathrm{~J}$. Thomas McCarthy, Trademarks and Unfair Competition $\$$ 31:139 (4th ed. 2012).

290 Louis Vuitton, 507 F.3d at 261.

291 Elvis Presley Enters., Inc. v. Capece, 950 F. Supp. 783, 795 (S.D. Tex. 1996), rev'd, 141 F.3d 188 (5th Cir. 1998); see also, e.g., Utah Lighthouse Ministry v. Found. for Apologetic Info. \& Research, 527 F.3d 1045, 1057 (10th Cir. 2008); Hormel Foods Corp. v. Jim Henson Prods., Inc., 73 F.3d 497, 505 (2d Cir. 1996).

292 See, e.g., MasterCard Int'l Inc. v. Nader 2000 Primary Comm. Inc., 70 U.S.P.Q.2d 1046, 1050-51 (S.D.N.Y. 2004); Am. Family Life Ins. Co. v. Hagan, 266 F. Supp. 2d 682, $690-92$ (N.D. Ohio 2002) (finding plaintiff unlikely to prevail on trademark infringement claim on the basis of likelihood of confusion test without invoking the First Amendment but finding that trademark dilution claim "[ran] afoul of the First Amendment"). In contrast to the ad hoc balancing approach in trademark cases, or the failure to recognize the political speech issues at work in Henley, a court determined in the context of a right of publicity claim that the First Amendment rights of a merchandiser that sold posters with a comedian's picture outweighed the publicity claim of the comedian who ran a mock campaign for president. Paulsen v. Personality Posters, Inc., 299 N.Y.S.2d 501, 507 (N.Y. Sup. Ct. 1968). The court emphasized the premium the First Amendment places on political speech, even if "tongue in cheek." See id. 
speech concerns in trademark law: (1) fair use defenses and (2) the Rogers v. Grimaldi ${ }^{293}$ test. These approaches are discussed below.

\section{Fair Use Defenses and Necessity}

Trademark defendants engaged in expressive activity can potentially turn to two fair use defenses. Descriptive fair use, a statutory affirmative defense, treats those uses of a mark that describe a defendant's product as noninfringing. ${ }^{294}$ It extends only to a use that "is descriptive of and used fairly and in good faith only to describe the goods and services of [the defendant]" and is a use "otherwise than as a mark." 295 For example, Ocean Spray could describe its cranberry juice as "sweet-tart" without infringing on the trademark for SweeTARTS candy because "sweet-tart" was only used to describe the properties of the defendant's juice and not as a brand. ${ }^{296}$

The descriptive fair use defense potentially implicates expressive conduct. ${ }^{297}$ At times, courts have used it to protect expressive activity extending beyond mere descriptions of goods and services, including uses by the news media. For example, the Seventh Circuit used the doctrine to permit the Chicago Tribune to sell t-shirts carrying the front-page headline "THE JOY OF SIX" to commemorate the Chicago Bulls' sixth NBA championship, even though the term was a registered trademark. 298 On most occasions, however, the defense has been read relatively narrowly and has not been the subject of extensive free expression arguments. ${ }^{299}$

293 Rogers v. Grimaldi, 875 F.2d 994 (2d Cir. 1989).

294 See 15 U.S.C. $\$ 1115(b)(4)$ (2006).

295 Id.

296 See Sunmark, Inc. v. Ocean Spray Cranberries, Inc., 64 F.3d 1055, 1057-58 (7th Cir. 1995).

297 See S.F. Arts \& Athletics, Inc. v. U.S. Olympic Comm., 483 U.S. 522, 565 (1987) (Brennan, J., dissenting) ("The fair-use defense also prevents the award of a trademark from regulating a substantial amount of noncommercial speech.").

298 See Packman v. Chi. Tribune Co., 267 F.3d 628, 633, 641 (7th Cir. 2001); see also WCVBTV v. Bos. Athletic Ass'n, 926 F.2d 42, 46 (1st Cir. 1991) (invoking fair use defense to allow television station to use trademarked term "Boston Marathon" in its coverage of the race). In addition, media organizations charged with trademark dilution can utilize Lanham Act section $43(c)(4)(C)$ (codified at 15 U.S.C. $\S 1125(c)(3)(B)(2006)$ ), a statutory exemption for "[a]ll forms of news reporting and news commentary." No similar exemption exists in the trademark infringement context.

299 See McGeveran, supra note 212, at 82-88; see also Graeme B. Dinwoodie \& Mark D. Janis, Trademarks and Unfair Competition: Law \& Policy 711 (3d ed. 2010) ("Trademark fair use is a relatively underdeveloped doctrine, with few reported decisions."). For an argument that the descriptive fair use defense inadequately safeguards the public's interest in free use of descriptive terms, see Lisa P. Ramsey, Descriptive Trademarks and the First Amendment, 70 TenN. L. Rev. 1095, 1167-69 (2003). 
The second variety of fair use is "nominative fair use." It finds its origins in the common law, not statute, and has proven, thus far, somewhat more nimble than the descriptive fair use defense. ${ }^{300}$ In the Ninth Circuit, the nominative fair use test is applied when the defendant uses the plaintiff's trademark only to identify the plaintiff's product and not to brand its own product. ${ }^{301}$ For example, the Ninth Circuit viewed a merchandiser's unauthorized use of Princess Diana's name and image on commemorative plates as an instance of nominative fair use because the merchandiser used Diana to identify Diana and not to identify its own company. ${ }^{302}$ The Third and Fifth Circuits, and numerous district courts outside of those circuits, have also recognized the viability of a nominative fair use defense. ${ }^{303}$

Graeme Austin describes the nominative fair use defense as a judicial effort to safeguard expressive freedoms even where confusion may exist. ${ }^{304}$ As outlined by the Ninth Circuit in the first case explicitly recognizing nominative fair use, New Kids on the Block v. News America Publishing, ${ }^{305}$ the defense requires that:

First, the product or service in question must be one not readily identifiable without use of the trademark; second, only so much of the mark or marks may be used as is reasonably necessary to identify the product or service; and third, the user must do nothing that would, in conjunction with the mark, suggest sponsorship or endorsement by the trademark holder. ${ }^{306}$

These three prongs are meant to balance the public's interest in avoiding confusion with the separate, communicative interest in using someone else's mark. ${ }^{307}$ As the Ninth Circuit pointed out when it inaugurated the test, "it is often virtually impossible to refer to a particular product for purposes of comparison, criticism, point of reference or any other such purpose without using the mark." ${ }^{308}$

300 See New Kids on the Block v. News Am. Publ'g, Inc., 971 F.2d 302, 308 (9th Cir. 1992) (noting that "nominative use of a mark" is "outside the strictures of trademark law"). Part II.D further discusses how the common law versus statutory nature of a regime impacts its flexibility, including its ability to address First Amendment concerns.

301 See New Kids, 971 F.2d at 308.

302 See Cairns v. Franklin Mint Co., 292 F.3d 1139, 1154-55 (9th Cir. 2002).

303 See Mary LaFrance, Understanding Trademark Law 325-26 (2d ed. 2009).

304 See Graeme W. Austin, Tolerating Confusion About Confusion: Trademark Policies and Fair Use, 50 ArIz. L. Rev. 157, 178-79 (2008).

305 New Kids on the Block v. News Am. Publ'g, Inc., 971 F.2d 302 (9th Cir. 1992).

306 Id. at 308 (citation omitted).

307 See id. at $307-08$.

308 Id. at 306. 
Like copyright fair use, the nominative fair use test has been converted, at times, into an inquiry on necessity. ${ }^{309}$ One of the prongs asks judges to examine how much of the plaintiff's work was appropriated by the defendant and whether that borrowing was "reasonably necessary to identify the product or service." 310 So, for example, when determining whether use of the mark "Beach Boys" constituted nominative fair use, the court investigated whether the defendant used the full phrase "Beach Boys" and whether he used a distinctive logo "or anything else that isn't needed." 311 The Third Circuit, in its own restatement of the nominative fair use test, goes so far as to interrogate the necessity of the defendant's use three times, asking if use of the mark is necessary to describe the plaintiff's product or service, if such use is necessary to describe the defendant's product or service, and whether the quantum of the plaintiff's mark used by the defendant is necessary to describe the plaintiff's products or services. ${ }^{312}$

Courts have also limited the reach of both fair use defenses by grounding them in the rationale of consumer protection rather than free expression. ${ }^{313}$ In other words, only uses that can accomplish their communicative goals without confusing consumers will likely enjoy immunity from infringement liability. ${ }^{314}$ With regard to descriptive fair use, the Supreme Court recently decided in KP Permanent MakeUp, Inc. v. Lasting Impression I, Inc. ${ }^{315}$ that a defendant should not have to disprove likelihood of confusion to enjoy the defense. ${ }^{316}$ But, the Court also suggested that likelihood of confusion would have some relevance to the question of whether the requirements for the defense have been satisfied. ${ }^{317}$ The Court's refusal to allow for a completely independent consideration of the defense separate from the likelihood of confusion analysis has compromised the ability of descriptive fair use to truly protect expressive interests. ${ }^{318}$ Similarly, courts often read the nominative fair use test in such a way as to

309 See, e.g., id. at 308 (noting that the newspapers "reference the New Kids only to the extent necessary to identify them").

310 Id.

311 Brother Records, Inc. v. Jardine, 318 F.3d 900, 908 (9th Cir. 2003) (quoting New Kids, 971 F.2d at 308) (internal quotation marks omitted).

312 See Century 21 Real Estate Corp. v. Lendingtree, Inc., 425 F.3d 211, 228 (3d Cir. 2005).

313 See, e.g., New Kids, 971 F.2d at 307-08 (defining nominative use as one that "does not attempt to capitalize on consumer confusion").

314 See id.

315 KP Permanent Make-Up, Inc. v. Lasting Impression I, Inc., 543 U.S. 111 (2004).

316 See id. at 118.

317 See id.

318 See Austin, supra note 304, at 185-89; McGeveran, supra note 212, at 84-85. 
merely reinstate the likelihood of confusion analysis, thereby reducing that doctrine's value as an independent defense for expressive activity as well. ${ }^{319}$ In one reading, the defense only applies when no prima facie infringement (i.e., a likelihood of confusion) exists in the first place. $^{320}$

\section{The Rogers Test and Commerciality}

Before 1989, some courts balanced trademark rights with free speech by inquiring whether a defendant could engage in "alternative avenues" of expression that did not intrude upon a mark holder's rights. 321 As with the nominative fair use test, the "alternative avenues" test effectively limits excusable uses of a trademark to instances of necessity. The test is modeled on the Supreme Court's ruling that a private shopping mall's decision to prohibit distribution of handbills did not violate the First Amendment because the plaintiffs had alternative means to distribute their messages. ${ }^{322}$ The alternative avenues test similarly asks if other mechanisms are suitable for the same artistic statement. ${ }^{323}$ If the artist defendant can communicate its message in another viable way, then any First Amendment defense fails. Hence, the Second Circuit court enjoined a defendant's release of a pornographic film showcasing actresses wearing (and not wearing) the trade dress of the Dallas Cowboys Cheerleaders because the court believed that the filmmaker had other possible mechanisms to "comment on 'sexuality in athletics." "\$24 In another case, insurance firm Mutual of Omaha convinced the Eighth Circuit that a defendant producing t-shirts and coffee mugs emblazoned with the words "Mutant of Omaha," the legend "Nuclear Holocaust Insurance," and a design featuring an emaciated head wearing a feather bonnet infringed the firm's word mark and famous "Indian head" logo. ${ }^{325}$ The Eighth Circuit explained that, because the defendant could express its antinuclear message without reference to the insurance company, or could use alternative media such as editorials in books or magazines, the court's decision in favor of Mutual of Omaha did not implicate the

319 See McGeveran, supra note 212, at 97.

320 See Century 21 Real Estate Corp. v. Lendingtree, Inc., 425 F.3d 211, 220-21 (3d Cir. 2005); McGeveran, supra note 212, at 84-85.

321 See, e.g., Dall. Cowboys Cheerleaders, Inc. v. Pussycat Cinema, Ltd., 604 F.2d 200, 206

(2d Cir. 1979).

322 Lloyd Corp. v. Tanner, 407 U.S. 551, 567 (1972).

323 See Dall. Cowboys, 604 F.2d at 206 (quoting Lloyd Corp., 407 U.S. at 567).

324 Id.

325 Mut. of Omaha Ins. Co. v. Novak, 836 F.2d 397, 398 (8th Cir. 1987). 
First Amendment. ${ }^{326}$ The rights of the trademark owner need not, the court explained, "yield to the exercise of First Amendment rights under circumstances where adequate alternative avenues of communication exist." 327

Then, in 1989, the Second Circuit introduced a new influential test for balancing consumer protection with expressive freedom. Rogers $v$. Grimaldi expressly repudiated the alternative avenues test. ${ }^{328}$ The actual case involved a fictional film about two Italian cabaret performers that imitate Ginger Rogers and Fred Astaire. ${ }^{329}$ The film was titled "Ginger and Fred." 330 The real Ginger Rogers sued the filmmaker for trademark infringement. ${ }^{331}$ Instead of simply asking whether the title was likely to confuse consumers, or whether the filmmaker could have made his point in other ways, the Rogers court announced an alternative inquiry: whether "the title has no artistic relevance to the underlying work whatsoever, or, if it has some artistic relevance, [whether] the title explicitly misleads as to the source or the content of the work." ${ }^{332}$ As the court explained, while the alternative avenues test may be appropriate for assessing First Amendment claims against landowners that restrict the physical location where speech may occur, the test proved overly restrictive in the context of trademark law where a trademark owner's infringement suit not only influences the location but also the content of the defendant's

326 See $i d$. at 402 .

327 Id. (quoting Lloyd Corp., 407 U.S. at 567) (internal quotation marks omitted). The alternative avenues test is not particularly speech friendly-an observation highlighted by the outcomes of both the Mutual of Omaha and Dallas Cowboys cases as well as several other cases. See, e.g., Dr. Seuss Enters., L.P. v. Penguin Books USA, Inc., 924 F. Supp. 1559, 1573 (S.D. Cal. 1996); Reddy Commc'ns, Inc. v. Envtl. Action Found., Inc., 199 U.S.P.Q. 630, 634 (D.D.C. 1977). As two trademark practitioners characterize the test, "the First Amendment is implicated only where a title is so intimately related to the subject matter of a work that the author has no alternative means of expressing what the work is about." Kelly \& Jordan, supra note 284, at 1364.

328 See Rogers v. Grimaldi, 875 F.2d 994, 999 (2d Cir. 1989). Today, although the alternative avenues test still curries some favor in the Eighth Circuit, see Am. Dairy Queen Corp. v. New Line Prods., Inc., 35 F. Supp. 2d 727, 734 (D. Minn. 1998), most other courts have rejected it. See McGeveran, supra note 212, at 98-100; see also Pratheepan Gulasekaram, Policing the Border Between Trademarks and Free Speech: Protecting Unauthorized Trademark Use in Expressive Works, 80 WASH. L. REv. 887, 903 (2005) (discussing the "compelling" balance struck by the Rogers court between the "public interest in avoiding confusion" and "the public interest in free speech"). But see Dr. Seuss, 924 F. Supp. at 1573.

329 See Rogers, 875 F.2d at 996-97.

330 Id. at 997.

331 See id.

332 Id. at 999. 
speech. ${ }^{333}$ The court stressed the need for a new balancing mechanism that put the judicial thumb more firmly on the defendant's side of the scale. ${ }^{334}$ Although the "Ginger and Fred" title plainly would have failed the "alternative avenues" test, the title was sufficiently related to the underlying work to meet the Second Circuit's new standard. ${ }^{335}$

In the years since the introduction of the Rogers test, other courts have adopted it and added new glosses to it. For example, both the Second Circuit and other jurisdictions soon expanded the reach of the test beyond titles and celebrity names to all "Lanham Act claims against works of artistic expression." ${ }^{336}$ Generally, courts ask two questions under the Rogers test: (1) whether use of the plaintiff's trademark is "artistic[ally] relevant" to the defendant's work; and (2) whether use of the plaintiff's trademark is "explicitly mislead[ing]." ${ }_{337}$ With regard to the first inquiry, courts have interpreted artistic relevance broadly, giving much deference to the vision of defendants. ${ }^{338}$ As the Ninth Circuit explained, "the level of relevance merely must be above zero." 339 Interpreting this "above zero" standard, a district court noted that the first prong of the Rogers test is satisfied even if the association between use of the trademark and the artist's underlying message is "tenuous." 340 Hence, when the video game Grand Theft Auto, in depicting a Los Angeles-like city, borrowed from the trademark and trade dress of an L.A. strip club, the court found that the game met the artistic relevance standard. ${ }^{341}$ Another court excused a pornographic film's use of the trademark "Route 66 " on similar grounds. ${ }^{342}$

333 See id.

334 See id.

335 See id. at 1001.

336 Cliffs Notes, Inc. v. Bantam Doubleday Dell Publ'g Grp., Inc., 866 F.2d 490, 495 (2d Cir. 1989); see E.S.S. Entm't 2000, Inc. v. Rock Star Videos, Inc., 547 F.3d 1095, 1099 (9th Cir. 2008) ("Although [the Rogers test] traditionally applies to uses of a trademark in the title of an artistic work, there is no principled reason why it ought not also apply to the use of a trademark in the body of the work."); Volkswagen AG v. Dorling Kindersley Publ'g., Inc., 614 F. Supp. 2d 793, 810 (E.D. Mich. 2009); see also Elizabeth L. Rosenblatt, Rethinking the Parameters of Trademark Use in Entertainment, 61 FLA. L. REv. 1011, 1025 (2009) ("In circuits that apply the Rogers standard, a gradual consensus has arisen that it should apply to uses of marks in the body of an expressive work as well as titular uses.").

337 See E.S.S. Entm't 2000, 547 F.3d at 1099.

338 See, e.g., id. at 1100.

339 Id.

340 See Roxbury Entm't v. Penthouse Media Grp., Inc., 669 F. Supp. 2d 1170, 1176 (C.D.

Cal. 2009).

341 See E.S.S. Entm't 2000, 547 F.3d at 1096, 1100.

342 See Roxbury Entm't, 669 F. Supp. 2d at 1172, 1175-76. 
Once artistic relevance is shown, a court moves on to determine if the use of the plaintiff's trademark was explicitly misleading. To be explicitly misleading, a "defendant's work must make some affirmative statement of the plaintiff's sponsorship or endorsement, beyond the mere use of plaintiff's name or other characteristic." 343 Requiring an affirmative additional statement by the defendant renders the second half of the Rogers inquiry highly protective of speech-related defenses. Moreover, in evaluating this prong, courts have stressed the importance of keeping the burden of proof in expressive use cases on the plaintiff. ${ }^{344}$

Furthermore, even in situations where the defendant's work misleads as to its source or content, under the Rogers test courts eschew standard application of the likelihood of confusion factors used in typical trademark infringement cases. ${ }^{345}$ Instead, in the Second Circuit, the "likelihood of confusion must be particularly compelling" before First Amendment concerns may be overcome. ${ }^{346}$ Although the Ninth Circuit has not adopted this "particularly compelling" standard, it has set up its own inquiry that replaces the traditional multi-factor likelihood of confusion test with a judicial assessment tilted in the artist's favor. ${ }^{347}$ For example, when Mattel sued Danish band Aqua for titling one of its songs "Barbie Girl," the Ninth Circuit noted that applying the traditional likelihood of confusion analysis "fails to account for the full weight of the public's interest in free expression." ${ }^{448}$ Instead, the court affirmed summary judgment for Aqua because it found the song title both artistically relevant and not explicitly misleading of

343 Dillinger, LLC v. Elec. Arts, Inc., No. 1:09-CV-1236-JMS-DKL, 2011 WL 2457678, at *6 (S.D. Ind. June 16, 2011) (emphasis added) (citing E.S.S. Entm't 2000, 547 F.3d at 1101; Rogers v. Grimaldi, 875 F.2d 994, 1001 (2d Cir. 1989)).

344 See Rogers, 875 F.2d at 999-1001 (noting that use of "words explicitly signifying endorsement, such as the phrase in a subtitle of 'an authorized biography' would be sufficiently explicit to be actionable, if false," but that evidence that a trademark's use "might implicitly suggest that the named celebrity had endorsed the work or had a role in producing it" is "outweighed by the danger of restricting artistic expression").

345 See, e.g., Twin Peaks Prods., Inc. v. Publ'ns Int'l, Ltd., 996 F.2d 1366, 1379 (2d Cir. 1993).

346 Id. (emphasis added); Lemme v. Nat'l Broad. Co., 472 F. Supp. 2d 433, 446 (E.D.N.Y. 2007) (emphasis added) (quoting Twin Peaks Prods., 996 F.2d at 1379); see Syler v. Woodruff, 610 F. Supp. 2d 256, 265 (S.D.N.Y. 2009); No Fear, Inc. v. Imagine Films, Inc., 930 F. Supp. 1381, 1383-84 (C.D. Cal. 1995).

347 The Ninth Circuit has taken a similar approach when evaluating the nominative fair use defense, requiring defendants to establish three requirements to satisfy the defense that are meant to replace the standard likelihood of confusion analysis. See New Kids on the Block v. News Am. Publ'g, Inc., 971 F.2d 302, 308 (9th Cir. 1992).

348 Mattel, Inc. v. MCA Records, Inc., 296 F.3d 894, 899-900 (9th Cir. 2002). 
consumers. ${ }^{349}$ Likewise, in finding that the public could not reasonably believe the Play Pen strip club authorized or sponsored Grand Theft Auto, the court determined, without resorting to a likelihood of confusion analysis, that the game was not "explicitly misleading" under the Rogers test. ${ }^{350}$ Similarly, in the Eleventh Circuit, rather than proceeding through the likelihood of confusion factors, a court found the Rogers test satisfied because nothing in the film "Club Dread" would explicitly mislead viewers into thinking that the film was associated with the trademark "Club Med" for resort services. ${ }^{351}$ In all three of these cases, the courts elected to immunize trademark uses on the ground that they did not obviously mislead even though application of the standard likelihood of confusion factors could potentially demonstrate consumer confusion.

The Rogers test represents a significant prospeech innovation in trademark law, permitting both uses that may confuse consumers and uses for which alternative mechanisms are available for making a similar expressive point. Despite this, the scholarly consensus seems to be that trademark law has achieved only mixed results in balancing trademark rights with expressive interests. ${ }^{352}$ One potential problem for defendants engaged in expressive uses stems from another line of trademark doctrine-one that borrows from copyright law. As with early right of publicity decisions and copyright's fair use analysis, modern trademark law often relies on the distinction between com-

349 See id. at 902

350 E.S.S. Entm't 2000, Inc. v. Rock Star Videos, Inc., 547 F.3d 1095, 1100-01 (9th Cir. 2008).

351 See Club Mediterranee, S.A. v. Fox Searchlight Pictures, Inc., No. 04-20273-CIV-MARTINEZ, 2004 U.S. Dist. LEXIS 3543, at *9-11 (S.D. Fla. Feb. 13, 2004); see also Volkswagen AG v. Dorling Kindersley Publ'g, Inc., 614 F. Supp. 2d 793, 801-02, 810 (E.D. Mich. 2009) (noting that if the Rogers test is satisfied, a likelihood of confusion test is unnecessary).

352 See, e.g., William McGeveran, The Trademark Fair Use Reform Act, 90 B.U. L. Rev. $2267,2267-70(2010)$. One problem is that these prospeech innovations have not taken root everywhere. Some circuits that have approved the Rogers test have yet to endorse the prodefendant glosses on that test embraced by the Second and Ninth Circuits. See Rosenblatt, supra note 336, at 1011, 1025 n.54. The requirement that any evidence of likelihood of confusion be "particularly compelling," the "more than zero" standard for artistic relevance, or the replacement of any likelihood of confusion analysis with the more speech-friendly evaluation of whether the defendant's use "explicitly misleads" have so far been largely confined to those two circuits. See id. at 1024-25, 1071-74. On the other hand, those two circuits are undeniably the most important jurisdictions in terms of sheer number of cases heard and the influence of their precedent. See, e.g., Beebe, supra note 144, at 566-68 (describing the Second and Ninth Circuits as the most influential circuits in the development of copyright's fair use doctrine). Thus, even though the law in this area is not uniform, the prospeech innovations introduced into trademark law by the Second and Ninth Circuits in recent years suggest that judges are more sensitive to the importance of free expression in this area than in the past. 
mercial and noncommercial speech to determine the role of the First Amendment. ${ }^{353}$

The commercial/noncommercial distinction threatens to obliterate whatever prospeech consequences can be found in the Rogers test. Courts currently differ on where to draw the line between commercial and noncommercial activity. ${ }^{354}$ Trademark cases rarely involve defendants lacking any profit motive whatsoever. Even those making artistic statements through others' brands often seek remuneration to allow their expressive activities to continue. ${ }^{355}$ A generous interpretation of "commercial activity" can push First Amendment concerns to the periphery. While copyright law treats the commercial/noncommercial distinction as merely one variable in the fair use calculus, ${ }^{356}$ some courts have made the distinction determinative in trademark cases. For example, the Third Circuit recently held that once the de-

353 Some scholars advocate a greater focus on the commercial/noncommercial distinction as a means of safeguarding expressive conduct. See McGeveran, supra note 352, at 2306-07. While one purpose of this Article is descriptive-distilling the relevant law in the intersection of trademark claims and free speech-there is also a basic question of how reliance on the commercial/ noncommercial distinction preserves (or fails to preserve) free expression. Determining what is and is not commercial speech remains uncertain. The Supreme Court has wrestled with this issue for seventy years, largely outside the context of trademark law, and seems no closer to a reasonably concrete definition. See Robert Post, The Constitutional Status of Commercial Speech, 48 UCLA L. Rev. 1, 7 (2000); see also Geoffrey D. Korff, Do Not Knock? Lovell to Watchtower and Back Again, 38 CAP. U. L. REv. 535, 536 (2010). If the uncertainty of judicial outcomes currently frustrates trademark defendants asserting defenses based on free expression, one should be skeptical that an even greater focus on the commercial/noncommercial line will give them greater predictive comfort. Interestingly for the purposes of this Article, with regard to the right of publicity, the courts seem to have chosen a different path, relying on evidence of "transformation" instead of noncommerciality, when recognizing a First Amendment defense. See supra notes 214-37 and accompanying text.

354 Compare Mut. of Omaha Ins. Co. v. Novak, 836 F.2d 397, 398-99, 403 (8th Cir. 1987) (affirming injunction against antinuclear activist for putting "Mutant of Omaha" on t-shirts and coffee mugs), with Smith v. Wal-Mart Stores, Inc., 537 F. Supp. 2d 1302, 1339-40 (N.D. Ga. 2008) (finding that $t$-shirts and other novelty merchandise imprinted with slogans like "Walocaust" by a Wal-Mart critic were noncommercial speech); see also White v. Samsung Elecs. Am., Inc., 989 F.2d 1512, 1520 (9th Cir. 1993) (Kozinski, J., dissenting from denial of rehearing en banc) ("In our pop culture, where salesmanship must be entertaining and entertainment must sell, the line between the commercial and noncommercial has not merely blurred; it has disappeared."); Kasky v. Nike, Inc., 45 P.3d 243, 279 (Cal. 2002) (Brown, J., dissenting) ("In today's world, the difference between commercial and noncommercial speech is not black and white."); Gulasekaram, supra note 328, at 936-40 (analyzing whether motion pictures are noncommercial speech and concluding that such analyses will become increasingly challenging for courts as product placement in films increases); Rosenblatt, supra note 336, at 1059 (maintaining that in trademark dilution law, which has a statutory exception for noncommercial use, no consensus exists on whether expressive uses of marks should always qualify for the exception).

355 See, e.g., Mut. of Omaha, 836 F.2d at 398.

356 See Campbell v. Acuff-Rose Music, Inc., 510 U.S. 569, 577 (1994) (quoting 17 U.S.C. $\S 107$ (2006)). 
fendant's use of a mark is labeled commercial speech, there is no need to address a First Amendment defense. ${ }^{357}$ The estate of a narrator for NFL films brought a false endorsement claim against the NFL for allowing his voice to be used in a twenty-two minute film called "The Making of Madden NFL 06." 358 Once the court determined that the film was a commercial advertisement for the videogame John Madden Football, the court explained that it no longer had any obligation to address First Amendment concerns, including through application of the Rogers test. ${ }^{359}$ The court explained that its ruling was consistent with other courts that "constru[ed] the Lanham Act narrowly to avoid a conflict with the First Amendment." 360 Hence, unlike much of modern right of publicity doctrine, which has chosen to ignore the distinction between activities for profit and those not for profit, ${ }^{361}$ trademark law continues to downgrade expressive activities when they come in a "commercial" package. 362

Another criticism of trademark doctrine's accommodation for expressive activity is that the free speech defenses described above often require detailed factual analyses resembling the standard likelihood of confusion analysis. For example, the nominative fair use test in the Ninth Circuit asks whether the defendant's use suggests endorsement by the plaintiff. ${ }^{363}$ This question is remarkably similar to the fundamental query at the heart of the likelihood of confusion analysis: is the defendant's use likely to confuse consumers? Consequently, defendants who are either unsure how this factual analysis will turn out or lack the will and resources to pursue a case through summary judgment will often capitulate rather than seek legal vindication of their free speech rights. Similar charges can be levied against the indeter-

357 See Facenda v. N.F.L. Films, Inc., 542 F.3d 1007, 1018 (3d Cir. 2008).

358 See id. at 1011.

359 See id. at $1016,1018$.

360 Id. at 1016.

361 See supra Part I.B.3.

362 While some circuits require commercial use of a mark to state a claim for infringement, others do not require it. Compare DaimlerChrysler AG v. Bloom, 315 F.3d 932, 936, 937 (8th Cir. 2003), with United We Stand Am., Inc. v. United We Stand, Am. N.Y., Inc., 128 F.3d 86, 92 (2d Cir. 1997). California, which seems to have pushed most in the direction of abandoning the commercial/noncommercial distinction in right of publicity cases, indicates that its focus on transformative uses of celebrity identity does not apply to advertising, which it labels "commercial speech." Comedy III Prods., Inc. v. Gary Saderup, Inc., 21 P.3d 797, 802 (Cal. 2001). But cf. Thoroughbred Legends, LLC v. Walt Disney Co., No. 1:07-CV-1275-BBM, 2008 WL 616253, at *11-12 (N.D. Ga. Feb. 12, 2008) (extending the newsworthiness exception to right of publicity claims to advertisement for a film).

363 See New Kids on the Block v. News Am. Publ'g, Inc., 971 F.2d 302, 308 (9th Cir. 1992). 
minate nature of the Rogers test and the ad hoc balancing approach. ${ }^{364}$ As Bill McGeveran has documented, trademark defenses that reimport the likelihood of confusion analysis and cannot be resolved early in the litigation offer little comfort to defendants making expressive use of trademarks. ${ }^{365}$ This criticism of trademark law is probably valid. If, given the high costs of litigation, defendants are bullied into abandoning expressive defenses that are likely meritorious, trademark law is not working as it should.

For the purposes of this Article, however, the doctrine and its evolution are the focus, rather than the criticisms described above. Trademark law has evolved in the last twenty years to provide additional recognition for speech-related defenses. In this respect, trademark doctrine appears more sensitive to First Amendment concerns than copyright law over the same period. At the same time, however, continued reliance on the commercial/noncommercial distinction prevents trademark from becoming the robust champion of free speech that modern right of publicity cases increasingly seem to be. The next Part explores some potential reasons why the strength of the doctrinal free speech defenses available in these three intellectual property regimes varies so markedly.

\section{Explaining the Divergent Evolution of Free Speech Defenses in Intellectual Property Law}

As the previous Part illustrates, a court's receptivity to an expression-based defense will differ dramatically depending on which intellectual property construct the defendant is charged with violating. The fault lines among copyright, trademark, and the right of publicity on this issue can be broken down into three main categories.

First, courts are much more willing to specifically invoke the First Amendment when evaluating a publicity rights case than when addressing copyright or trademark claims. ${ }^{366}$ In fact, analyses of the constitutionality of the plaintiff's requested prohibition of the defendant's

364 See McGeveran, supra note 212, at 102-14 (discussing this point in the context of ad hoc balancing). Different courts have arrived at different outcomes when applying the Rogers test to largely similar factual scenarios. For example, despite adopting the Rogers test, the Sixth Circuit reversed a grant of summary judgment in favor of the group Outkast, which titled one of its songs "Rosa Parks." Parks v. LaFace Records, 329 F.3d 437, 442, 450, 452-53 (6th Cir. 2003). Whereas the Ninth Circuit easily found that the title "Barbie Girl" had sufficient relevance to the song at issue, the Sixth Circuit was unwilling to extend the same interpretation to Outkast's song even though it contained the phrase "move to the back of the bus," which invoked the famous event that projected Ms. Parks into the public consciousness. See id. at 451-53.

365 See McGeveran, supra note 212, at 90-93.

366 See supra notes 205-12 and accompanying text. 
use of a celebrity persona often take center stage in publicity rights litigation. ${ }^{367}$ By contrast, courts rarely engage with the First Amendment in copyright cases, taking their cue from the Eldred decision, which held that any case falling within the "traditional contours" of copyright law receives a First Amendment pass. ${ }^{368}$ Copyright's idea/ expression dichotomy and statutory fair use defense are deemed to supply all necessary accommodation for expressive concerns. ${ }^{369}$ For trademark, constitutional references arise a bit more often, but are still infrequent, as courts typically rely on internal mechanisms for safeguarding free expression like the nominative fair use defense and the Rogers test. ${ }^{370}$

Second, the three regimes differ in how they treat those appropriations potentially most deserving of immunity from infringement: transformative and news-related uses. All told, despite the Supreme Court's rhetoric in Campbell, most expressive and transformative uses outside of parody stand little chance of success under copyright's fair use defense. ${ }^{371}$ This occurs because copyright law has adopted an analysis of the "purpose and character" fair use factor that only privileges those uses necessary to the defendant's expressive point. ${ }^{372} \mathrm{Par}-$ odies can meet this standard because a successful parody requires the audience to recognize the original in order to appreciate that the defendant is commenting on that original. ${ }^{373}$ Satires and other artistic appropriations of copyrighted works, however, fail this test because the defendant possibly can communicate a similar message through alternative means. ${ }^{374}$ This cramped interpretation of what is and is not transformative also disadvantages news-related uses as judges are encouraged to second-guess broadcasters' need to use a copyrighted work to communicate their message to the public. ${ }^{375}$

These results are particularly striking when compared to similar analyses involving the right of publicity and trademark law. Like copyright law, the right of publicity relies on a transformative use test to vindicate defendants' potential First Amendment interests. ${ }^{376}$ Unlike

367 See supra notes $206-12$ and accompanying text.

368 Eldred v. Ashcroft, 537 U.S. 186, 221 (2003); see supra notes 55-64 and accompanying text.

369 See supra notes 65-66 and accompanying text.

370 See supra Part I.C.

371 See supra Part I.A.2.

372 See supra Part I.A.2.

373 See supra Part I.A.2.a.

374 See supra Part I.A.2.a.

375 See supra Part I.A.2.b

376 See supra Part I.B.2.a. 
copyright law, however, emerging jurisprudence in the right of publicity context has raised transformative use to a complete defense in and of itself-not merely as part of a balancing test of factors. ${ }^{377}$ Moreover, right of publicity jurisprudence has explicitly rejected a parody/ satire distinction and has broadly defined transformative use. ${ }^{378} \mathrm{At}$ the same time, courts have introduced a broad "newsworthiness" exception to provide sufficient room for the use of celebrity names and images in news-related activities. ${ }^{379}$ Thus, in sharp contrast to the dominant conception of copyright fair use, right of publicity "fair use" is not about necessity. Instead, "transformative" and "newsworthy" uses have emerged as stand-alone defenses to a prima facie claim of infringement of publicity rights. Similarly, in contrast to the plaintifffriendly likelihood of confusion test that generally governs Lanham Act trademark relief, the Rogers test has provided a powerful antidote to any prima facie Lanham Act claim that threatens to muzzle an artistically relevant use of a trademark, so long as use of the trademark is not "explicitly misleading." ${ }^{380}$ Courts have read trademark's nominative fair use test, on the other hand, in such a way as to only allow "necessary" references to another's product, and the presence of any likely consumer confusion generally prevents a defendant from succeeding in a descriptive fair use defense. ${ }^{381}$

Third, copyright and trademark courts continue to put great emphasis on the presence of commercial motivation. In copyright cases, courts rely more on market harm than any other fair use factor and often jettison any consideration of expressive interests after deeming the defendant's activity commercial and, therefore, erosive of the plaintiff's potential licensing opportunities. ${ }^{382}$ A finding of commercial use can also drive the outcome of trademark infringement cases and even block application of speech-friendly defenses like the Rogers test. ${ }^{383}$ In contrast, the right of publicity jurisprudence has begun to abandon the ambiguous and inconsistently applied commercial/noncommercial distinction. ${ }^{384}$ Relatedly, if the allegedly infringing use of a celebrity's likeness in a right of publicity case is transformative, the amount of harm that might occur to a plaintiff's actual or potential

\footnotetext{
377 See supra notes 225-37 and accompanying text.

378 See supra notes 225-37 and accompanying text.

379 See supra Part I.B.2.b.

380 See supra Part I.C.3.

381 See supra notes 309-12 and accompanying text.

382 See supra Part I.A.3.b.

383 See supra notes 353-62 and accompanying text.

384 See supra Part I.B.3.
} 
licensing market does not matter ${ }^{385}$ The defendant's use is absolutely shielded from liability. In short, in the right of publicity context, market harm does not diminish a transformative use defense-the defendant's expressive speech is tolerated no matter the economic damage done to the private rightsholder. These differences are summarized in the table below.

\section{Summary of Current Doctrinal Accommodations for FREE EXPRESSION}

\begin{tabular}{|c|c|c|c|}
\hline & Copyright $^{386}$ & Right of Publicity ${ }^{387}$ & Trademark $^{388}$ \\
\hline $\begin{array}{l}\text { EXPRESS INVOCA- } \\
\text { TION OF FIRST } \\
\text { AMENDMENT }^{389}\end{array}$ & $\begin{array}{l}\text { First Amendment } \\
\text { rarely invoked; } \\
\text { Supreme Court holds } \\
\text { no First Amendment } \\
\text { analysis necessary if } \\
\text { law being analyzed is } \\
\text { within "traditional } \\
\text { contours" of copyright }\end{array}$ & $\begin{array}{l}\text { Cases reference the } \\
\text { First Amendment } \\
\text { explicitly and fre- } \\
\text { quently }\end{array}$ & $\begin{array}{l}\text { Relatively little } \\
\text { explicit reference to } \\
\text { First Amendment in } \\
\text { cases }\end{array}$ \\
\hline \multirow[t]{3}{*}{ NECESSITY ${ }^{390}$} & $\begin{array}{l}\text { Recent greater empha- } \\
\text { sis on transformative- } \\
\text { ness but narrowly } \\
\text { defined as evidenced } \\
\text { by parody/satire and } \\
\text { transexpressive/trans- } \\
\text { purposive distinctions; } \\
\text { simultaneous emphasis } \\
\text { on effect on plaintiff's } \\
\text { market }\end{array}$ & $\begin{array}{l}\text { Transformativeness } \\
\text { broadly defined, } \\
\text { applied separately and } \\
\text { apart from other con- } \\
\text { cerns, and treated as } \\
\text { sufficient to trigger } \\
\text { First Amendment } \\
\text { immunity }\end{array}$ & $\begin{array}{l}\text { Most defenses prohib- } \\
\text { ited if use is confus- } \\
\text { ing; Rogers test is } \\
\text { defendant friendly, } \\
\text { however, because it } \\
\text { abandons inquiry into } \\
\text { likelihood of confusion } \\
\text { factors and generously } \\
\text { defines "artistic rele- } \\
\text { vance" }\end{array}$ \\
\hline & $\begin{array}{l}\text { Alternative avenues } \\
\text { still relevant to fair } \\
\text { use defense, particu- } \\
\text { larly when the plaintiff } \\
\text { argues that the work } \\
\text { is not a parody }\end{array}$ & $\begin{array}{l}\text { Rejection of alterna- } \\
\text { tive avenues test }\end{array}$ & $\begin{array}{l}\text { Rejection of alterna- } \\
\text { tive avenues test } \\
\text { (except for Eighth } \\
\text { Circuit) }\end{array}$ \\
\hline & $\begin{array}{l}\text { No particular defense } \\
\text { for news-related or } \\
\text { public interest uses }\end{array}$ & $\begin{array}{l}\text { Separate defense for } \\
\text { "newsworthiness" }\end{array}$ & $\begin{array}{l}\text { No particular defense } \\
\text { for news-related uses; } \\
\text { some consideration } \\
\text { occurs, however, via } \\
\text { descriptive fair use } \\
\text { defense }\end{array}$ \\
\hline $\begin{array}{l}\text { ROLE OF MARKET- } \\
\text { BASED } \\
\text { CONCERNS }^{391}\end{array}$ & $\begin{array}{l}\text { Commercial/noncom- } \\
\text { mercial distinction is a } \\
\text { critical component of } \\
\text { fair use analysis }\end{array}$ & $\begin{array}{l}\text { Move to replace com- } \\
\text { mercial/ noncommer- } \\
\text { cial distinction with } \\
\text { transformativeness } \\
\text { inquiry }\end{array}$ & $\begin{array}{l}\text { Some remaining } \\
\text { emphasis on commer- } \\
\text { cial/ noncommercial } \\
\text { distinction }\end{array}$ \\
\hline
\end{tabular}

385 See supra notes $259-70$ and accompanying text.

386 See supra Part I.A.

387 See supra Part I.B.

388 See supra Part I.C.

389 See supra Part I.A.1, I.B.1, I.C.1.

390 See supra Part I.A.2, I.B.2, I.C.2

391 See supra Part I.A.3, I.B.3, I.C.3. 


\begin{tabular}{|l|l|l|l|}
\hline & $\begin{array}{l}\text { Market harm to plain- } \\
\text { tiff's property right } \\
\text { defined broadly and } \\
\text { deemed the most } \\
\text { important factor in the } \\
\text { fair use test, often } \\
\text { trumping expressive } \\
\text { interests }\end{array}$ & $\begin{array}{l}\text { Market harm to plain- } \\
\text { tiff's property right } \\
\text { irrelevant in consider- } \\
\text { ing First Amendment }\end{array}$ & $\begin{array}{l}\text { Although market } \\
\text { harm not specifically } \\
\text { addressed, finding of } \\
\text { commercial use pre- } \\
\text { vents application of } \\
\text { Rogers test }\end{array}$ \\
\hline
\end{tabular}

To some degree, judges are aware of the free expression triple standard described above. Recent right of publicity decisions demonstrate a conscious effort to break with precedent and find distance from copyright doctrine. In Comedy III and Winter, the California Supreme Court took pains to contrast its own approach with copyright's fair use doctrine, in effect creating two separate First Amendment lenses depending on the intellectual property right at stake. Unlike prior cases suggesting an affinity between the right of publicity and copyright law, ${ }^{392}$ the court cautioned against employing copyright fair use analysis in right of publicity cases. ${ }^{393}$ Similarly, in a right of publicity case involving a defense based on parody, the Tenth Circuit

392 Before the prospeech innovations in right of publicity law, courts frequently borrowed from copyright's fair use test, justifying this move by suggesting affinities between the two types of intellectual property. See Comedy III Prods., Inc. v. Gary Saderup, Inc., 21 P.3d 797, 807-08 (Cal. 2001). In the Supreme Court's only treatment of the right of publicity, the Court emphasized the kinship between the two intellectual property regimes. See Zacchini v. Scripps-Howard Broad. Co., 433 U.S. 562, 573, 575-77 (1977). Just as a court might do in a copyright case, the Court keyed in on the effect of the defendant's use on the market for the plaintiff's act. See id. at 576; see also 2 McCARTHY, supra note 205, at $\$ 8: 27$ ("The majority looked primarily to the economic impact that defendant's use had upon the publicity value of plaintiff's performance."). Other courts followed suit and borrowed from copyright's fair use analysis in adjudicating right of publicity disputes. One court explained that " $[\mathrm{t}]$ his idea of creative comment precluding a right of publicity claim can be analogized to the doctrine of fair use in the copyright law." Estate of Presley v. Russen, 513 F. Supp. 1339, 1358 n.18 (D.N.J. 1981). Another court decided that the copyright fair use doctrine's treatment of parody should be used to evaluate parody defenses in right of publicity cases. Groucho Marx Prods., Inc. v. Day \& Night Co., 523 F. Supp. 485, 492-93 (S.D.N.Y. 1981), rev'd on other grounds, 689 F.2d 317 (2d Cir. 1982). A great deal of scholarly commentary in the 1980 s and 1990 s also supported importing fair use principles into the right of publicity analysis. See, e.g., Richard Ausness, The Right of Publicity: A "Haystack in a Hurricane," 55 TemP. L.Q. 977, 1048-53 (1982); Douglas J. Ellis, Comment, The Right of Publicity and the First Amendment: A Comment on Why Celebrity Parodies Are Fair Game for Fair Use, 64 U. Cin. L. Rev. 575, 612 (1996); Roberta Rosenthal Kwall, Is Independence Day Dawning for the Right of Publicity?, 17 U.C. Davis L. Rev. 191, 232 (1983); Samuelson, supra note 213, at 915. Borrowing from copyright's fair use doctrine did not necessarily lead to prospeech outcomes, however-a result that should not be surprising given this Article's earlier discussion of First Amendment defenses in copyright cases. See supra Part I.A. For example, in the right of publicity cases $r$ eferenced above, where copyright's treatment of "creative comment" and parody were brought to bear on the right of publicity, the celebrity plaintiffs won and First Amendment defenses were rejected. See Groucho Marx, 523 F. Supp. at 493; Estate of Presley, 513 F. Supp. at 1382 .

393 See Winter v. DC Comics, 69 P.3d 473, 478 (Cal. 2003); Comedy III, 21 P.3d at 807-08. 
found "little guidance" in cases seeking to "resolv[e] the tension between the First Amendment and ... other forms of intellectual property." 394 By contrast, courts continue to cite copyright law when evaluating expressive defenses in trademark disputes. For example, current trademark doctrine sometimes embraces the distinction between parody and satire articulated in copyright jurisprudence, which investigates the defendant's need to use the plaintiff's intellectual property. ${ }^{395}$ In one case rejecting a First Amendment defense, the court explained: "Just as in copyright, trademark infringement will be excused only where necessary to the purpose of the use." 396

Yet even where courts draw comparisons to the expressive defenses available in other intellectual property regimes, the cases do not articulate an underlying rationale for engaging in these comparisons. They simply note the differences or similarities between the doctrines and move on. The remainder of this Article explores potential reasons behind the different rules for addressing free speech across the three regimes. This Part argues that neither differences in the regimes' individual ideological underpinnings nor current judicial categorization of the speech interests at stake in each regime can explain the variance. Instead, the differences stem from a less principled

394 Cardtoons, L.C. v. Major League Baseball Players Ass'n, 95 F.3d 959, 970 (10th Cir. 1996). The Tenth Circuit explained that, unlike copyright and trademark, which "have built-in mechanisms [like the likelihood of confusion standard and the copyright fair use defense] that serve to avoid First Amendment concerns of this kind," Oklahoma's right of publicity law did not. Id. at 970-71. As a result, the court found it necessary to confront the First Amendment issue directly. Id. at 971 .

395 See Graeme B. Dinwoodie, Developing Defenses in Trademark Law, 13 LEwIs \& Clark L. Rev. 99, 139-40 n.157 (2009); see also, e.g., L.L. Bean, Inc. v. Drake Publishers, Inc., 811 F.2d 26, 27, 33 (1st Cir. 1987) (emphasizing that its holding protecting pornographic magazine's invocation of L.L. Bean's mark rested on finding that defendant's use was a parody).

396 Dr. Seuss Enters., L.P. v. Penguin Books USA, Inc., 924 F. Supp. 1559, 1573 (S.D. Cal. 1996). Jane Ginsburg speculates that trademark law's willingness to borrow from copyright law may stem from the large number of cases presenting overlapping claims of trademark and copyright infringement. Jane C. Ginsburg, Of Mutant Copyrights, Mangled Trademarks, and Barbie's Beneficence: The Influence of Copyright on Trademark Law, in TRADEMARK LAW \& THEORY: A Handbook of Contemporary Research 481, 492-93 (Graeme B. Dinwoodie \& Mark D. Janis eds., 2008). She speculates that once a court has determined that a defendant's use is privileged under the copyright fair use analysis, it is unlikely to use a separate analysis that concludes that the defendant's activity is not immunized under trademark law. See id. There may be some truth to this, but right of publicity claims often accompany trademark lawsuits as well. See Lee Goldman, Elvis is Alive, but He Shouldn't Be: The Right of Publicity Revisited, 1992 B.Y.U. L. REv. 597, 627 n.144. These lawsuits often result in bifurcated verdicts, where the plaintiff succeeds on the trademark claim but not on the right of publicity claim due to the two doctrines' different standards for assessing speech interests. See, e.g., PAM Media, Inc. v. Am. Research Corp., 889 F. Supp. 1403, 1409 (D. Colo. 1995) (denying defendant's motion for summary judgment on trademark claim but granting relief on right of publicity claim). 
or logically consistent source. The particular methods and histories of lawmaking that have been brought to bear on copyright, trademark, and the right of publicity jurisprudence are responsible for creating the current fault lines in their respective accommodations for free expression.

\section{A. Justifying the Plaintiff's Right}

A potential explanation for the varying doctrinal approaches to free expression may lie in the different ideological underpinnings of the three rights. If the theory behind one particular right suggests a more absolutist conception for that right than for others, this could explain why a court may be less receptive to expressive defenses to infringement of that right. ${ }^{397}$

One possibly relevant ideological fault line is that, while copyright and trademark protection are based on utilitarian considerations, publicity rights are often described in terms of natural rights. ${ }^{398}$ Copyright, at least constitutionally, is justified on the basis of social consequences, not necessarily as a natural right inherent in the act of authorship. ${ }^{399}$ Although some consideration of authors' moral rights certainly creeps into copyright jurisprudence, the predominant purpose of copyright law is to create a mechanism that stimulates the production of creative works for society to enjoy. ${ }^{400}$ Similarly, modern trademark law derives its justification from the larger consequences of brand name protection. ${ }^{401}$ Trademark law eschews most talk of the natural rights of mark creators and instead seeks to benefit consumers by preventing confusion in the marketplace. ${ }^{402}$ As a result, trademark law should yield when no confusion exists, or other social benefits outweigh the potential for confusion. ${ }^{403}$ In contrast, the right of publicity

397 To wit, if one form of intellectual property is more appropriately conceived in absolute, Blackstonian terms for its owners, rather than potential users or infringers, that might explain why that form of intellectual property sees a less deferential approach to the expressive interests of users or infringers.

398 See Daniel J. Solove \& Paul M. Schwartz, Privacy and the Media 212-13 (2008) (observing that "[o]ne of the predominant rationales for the right of publicity is that the celebrity, through her labor, creates her persona"); Melville B. Nimmer, The Right of Publicity, 19 LAw \& CONTEMP. PROBS. 203, 216 (1954) (connecting the right of publicity to every person's moral right to "the fruit of his labors").

399 See Shyamkrishna Balganesh, Foreseeability and Copyright Incentives, 122 HARv. L. REV. 1569, 1573 (2009).

400 See Paul Goldstein, International Copyright: Principles, Law, and Practice 6-8 (2001).

401 See Bretford Mfg., Inc. v. Smith Sys. Mfg. Corp., 419 F.3d 576, 579 (7th Cir. 2005).

402 See id. at 579, 581 ("Consumers rather than producers are the objects of the law's solicitude.").

403 Cliffs Notes, Inc. v. Bantam Doubleday Dell Publ'g Grp., Inc., 886 F.2d 490, 495 (2d Cir. 
often draws support from a moral argument based on the right of individuals to control the management of their personae. ${ }^{404}$ The right is sometimes characterized as the just reward for a celebrity's investment in creating a personality that resonates with the public. ${ }^{405}$ Others have justified the right as a necessary legal entitlement for individual self-definition, not for its role in producing aggregate social good. ${ }^{406}$

Yet this split between utilitarian and moral considerations seems unlikely to account for the differences observed in Part I. First, as indicated above, a variety of justifications have been offered for publicity rights protections, some relying on the same considerations of economic incentives and consumer protection found in copyright and trademark law, respectively. ${ }^{407}$ Meanwhile, whatever its origins, copyright doctrine has long transcended utilitarian concerns and has frequently drawn on labor-desert and personhood theories for its raison d'être. ${ }^{408}$ Finally, with trademark's expansion into the regulation of activities beyond the point-of-sale and its recognition of dilution causes of action, trademark law increasingly appears to protect against more than just a likelihood of consumer confusion. ${ }^{409}$ Hence, the ide-

1989) (noting that "somewhat more risk of confusion is to be tolerated when a trademark holder seeks to enjoin artistic expression such as a parody").

404 See 1 McCarthy, supra note 205, at § 2:1; see also Roberta Rosenthal Kwall, Preserving Personality and Reputational Interests of Constructed Personas Through Moral Rights: A Blueprint for the Twenty-First Century, 2001 U. ILL. L. REv. 151, 158-60.

405 See, e.g., Carson v. Here's Johnny Portable Toilets, Inc., 698 F.2d 831, 839 (6th Cir. 1983) (Kennedy, J., dissenting); Uhlaender v. Henricksen, 316 F. Supp. 1277, 1282 (D. Minn. 1970).

406 See Alice Haemmerli, Whose Who? The Case for a Kantian Right of Publicity, 49 DuKE L.J. 383, 411-428 (1999); Mark P. McKenna, The Right of Publicity and Autonomous Self-Definition, 67 U. PrTT. L. Rev. 225, 231 (2005).

407 See supra Part I.B; see also Steven Semeraro, Property's End: Why Competition Policy Should Limit the Right of Publicity, 43 ConN. L. REv. 753, 760-62 (2011) (describing various theoretical justifications for the right of publicity).

408 See Justin Hughes, The Philosophy of Intellectual Property, 77 GEo. L.J. 287, 305 (1988) ("The legal history of intellectual property contains many allusions to the value-added theory[,]" also known as the "'labor-desert' theory."). "Labor-desert" theory holds that when an individual "produces something of value to others-something beyond what morality requires the laborer to produce-then the laborer deserves some benefit for it." Id. This theory stems from the Lockean ideal that people "have the right to enjoy the fruits of their labor, even when the labors are intellectual." Id. at 301.

409 See Graeme W. Austin, Trademarks and the Burdened Imagination, 69 Brook. L. Rev. $827,833,853-54$ (2004) (explaining that a contemporary "rationale for trademark protection is concerned more obviously with protecting firms from 'misappropriation' of the value they have built up in brands than with protecting consumers from confusion"). Austin points out that survey evidence suggesting the likelihood of consumer confusion by the defendant's conduct "carries weight in trademark infringement cases relatively infrequently." Id. at 834. 
ological disparities between these different forms of intellectual property may not be as stark as first observed.

More significantly, to the extent that the right of publicity is guided by moral considerations, this justification would seem to counsel in favor of less, not more, solicitude for expression-based defenses. A right in persona based on claims of a natural entitlement to the outward extensions of one's being should prove less likely to yield to concerns for the free dissemination of ideas than a right based on calculations of what is best for society in the aggregate. ${ }^{410}$ If anything, a right based on utilitarian considerations would seem more likely to take into account the societal welfare-enhancing aspects of expressive uses of someone else's property. Yet the doctrine has recently moved in the direction of greater free speech rights for right of publicity defendants. ${ }^{411}$ By contrast, copyright, which is (at least in theory) primarily guided by utilitarian considerations, appears the least friendly to defenses based on the need for free expression. ${ }^{412}$

Another line that might meaningfully divide the three regimes is whether the right at issue sounds in property or in tort. Historically, rights conceptualized as "property" rights are more plaintiff-focused than rights sounding in tort, which are based on a bilateral consideration of the relationship between the plaintiff and the defendant. ${ }^{413}$ Under a Blackstonian conception of property, a person holding a property right in a thing could assert an absolute right to exclude others from it, whereas someone injured by another's tortious conduct did not enjoy the same expectation of absolute privilege. ${ }^{414}$ For example, late nineteenth-century trademark law conceptualized fanciful and arbitrary marks (e.g., "Kodak" cameras and "Dutch Boy" paint) as "property" whereas merely descriptive marks (e.g., "Yellow Pages"

410 See Simone A. Rose, Will Atlas Shrug? Dilution Protection for "Famous" Trademarks: Anti-Competitive "Monopoly" or Earned "Property" Right?, 47 FLA. L. REV. 653, 688 n.133 (1995) ("I do not believe that intellectual property rights are best supported under a natural rights theory, as it fails to properly balance the public right to the free dissemination of ideas."). But see Wendy J. Gordon, A Property Right in Self-Expression: Equality and Individualism in the Natural Law of Intellectual Property, 102 YALE L.J. 1533, 1535 (1993) ("When the limitations in natural law's premises are taken seriously, natural rights not only cease to be a weapon against free expression; they also become a source of affirmative protection for free speech interests.").

411 See supra Part I.B.1.

412 See supra Part I.A.

413 See Mark Bartholomew, Advertising and the Transformation of Trademark Law, 38 N.M. L. Rev. 1,6 \& n.45 (2008).

414 See Robert G. Bone, Hunting Goodwill: A History of the Concept of Goodwill in Trademark Law, 86 B.U. L. REv. 547, 562-66 (2006) (contrasting property-based trademark rights with tort-based trademark rights). 
for a phone directory with yellow-colored pages) were not property and had to rely on the separate legal regime of "unfair competition" for protection. ${ }^{415}$ Significantly, descriptive marks (i.e., those not understood to be "property") were only eligible for protection when the plaintiff could show that consumers used the mark as a source identifier and that the defendant had intended to confuse those consumers. ${ }^{416}$ In contrast, the holder of a property interest in fanciful or arbitrary marks could receive injunctive relief without demonstrating either the meaning of the mark to the public or the defendant's bad intent. ${ }^{417}$ Hence, those defendants accused of infringing a mark conceptualized as property had fewer defenses available to them than those accused of infringing merely descriptive marks.

However, while real differences exist between property and tort claims, it does not appear that any one of the intellectual property rights at issue is necessarily deemed more "property"-like than any other. At times, all three of these rights have been characterized as property rights. ${ }^{418}$ Yet they are also often described as mere branches of tort law. ${ }^{419}$ Moreover, the distinction between property and tort does not carry the same weight today that it did in the nineteenth century. ${ }^{420}$ At times, courts may play with these terms and their historic meanings so as to either bolster or weaken the position of rights holders claiming that a defendant engaged in expressive use has infringed their rights. ${ }^{421}$ Many have noted that judges have used the language of property to justify decisions expanding the privileges of

415 See id.

416 See id. at 565-66.

417 See id. at 563-65. Modern trademark law abandons this distinction. Arbitrary, fanciful, and descriptive marks are all considered part of trademark law and proof of the defendant's bad intent, while relevant to assessing infringement, is not required for a successful infringement claim. See id. at 556-57, 606.

418 See, e.g., W. Diversified Servs., Inc. v. Hyundai Motor Am., Inc., 427 F.3d 1269, 1272 (10th Cir. 2005) (trademark); Taylor Corp. v. Four Seasons Greetings, LLC, 403 F.3d 958, 963 (8th Cir. 2005) (copyright); Kwall, supra note 2, at 1352 n.38 ("According to conventional wisdom, publicity cases involve a property interest ....").

419 See, e.g., Hard Rock Cafe Licensing Corp. v. Concession Servs., Inc., 955 F.2d 1143, 1148 (7th Cir. 1992) ("[W]e have treated trademark infringement as a species of tort . . ."); Charles v. City of Los Angeles, 757 F. Supp. 2d 989, 1003 (C.D. Cal. 2010) (describing the right of publicity as a "state tort claim"); Demetriades v. Kaufmann, 690 F. Supp. 289, 292 (S.D.N.Y. 1988) ("[C]opyright is analogous to a species of tort ....").

420 See Hanoch Dagan, Judges and Property 11 (May 14, 2011) (unpublished manuscript), available at http://papers.ssrn.com/sol3/papers.cfm?abstract_id=1841725 (maintaining that modern property rights often include limits on the ability of owners to exclude others and even specific rights of non-owners to be included).

421 See, e.g., S.F. Arts \& Athletics, Inc. v. U.S. Olympic Comm., 483 U.S. 522, 532 (1987) (positing that, through "the expenditure of labor, skill, and money," an entity may obtain a 
intellectual property rights holders. ${ }^{422}$ But in such cases, the terms represent rhetorical weapons in the judicial arsenal rather than accurate reflections of a particular right's ideological basis.

So, the theoretical underpinnings of these regimes do not seem to explain their disparate approaches to free speech. Instead, this Article must look in a different direction for an explanation.

\section{B. Judicial Perceptions of Litigants and the Value of Their Interests}

Another explanation for the divergence in the three regimes might relate to judicial perception of the litigants and the respective interests they represent. Specifically, the disparate doctrinal machinations detailed in Part I may unconsciously reflect the legitimacy courts perceive in the typical plaintiffs in these cases and an implicit judgment of the competing values at stake. If judges more naturally sympathize with copyright holders than trademark owners or celebrities, this might explain the current disparity in treatment of First Amendment defenses.

It is no secret that the content creation industries served by copyright law are among the most powerful in the United States, both economically and politically. ${ }^{423}$ There is great awareness of their contribution to the gross domestic product and economic growth as well as their critical place in the international marketplace. ${ }^{424}$ As a result, when the movie, music, publishing, and software industries

"limited property right" in a word such as "Olympic" and the existence of this "property right" can trump free speech concerns).

422 See, e.g., Mark A. Lemley, Property, Intellectual Property, and Free Riding, 83 TEx. L. REV. 1031, 1036 (2005).

423 See Marci A. Hamilton, Copyright Duration Extension and the Dark Heart of Copyright, 14 CARdozo ARTS \& ENT. L.J. 655, 659-60 (1996) (highlighting copyright policy "which benefits powerful lobbying interests" and has concentrated the power of copyright law in the entertainment industries). Hamilton describes "[t]he American entertainment industry as this century's business success story ... that makes billions of dollars, exports American culture ... by the ton, and persuades the peoples of so many foreign countries that America is the world's leader[.]" Id. at 655 . Hamilton also conjectures that the voice of the entertainment industry eclipses any other copyright voices and has a "narcotic effect" on Congress. Id. at 656.

424 Stephen E. Siwek, Economists Inc., Engines of Growth: Economic Contributions of the US Intellectual Property Industries 3 (2005), http://www.entertainmentecon.org/File/Report/NBCU_Study_Nov_2005.pdf ("The total IP industry had an approximate $20 \%$ share of U.S. private industry GDP in 2003 , but was responsible for nearly $40 \%$ of the growth achieved by all of U.S. private industry . . . Moreover, the total IP industry had approximately $40 \%$ of the GDP of U.S. exportable products and services yet contributed nearly $60 \%$ to the growth of U.S. exportable high-value-add products and services."). Therefore, the IP industry accounted for " $19.8 \%$ of total U.S. private industry contribution to GDP in 2003 , and $39.9 \%$ of the contribution of U.S. exportable products and services to the GDP." Id.; see also, e.g., Industry Facts: Economic Data, ENTM'T SofTware Ass'N, http://www.theesa.com/ 
bring suits against alleged infringers, the courts' emphasis on the alternative means by which the defendants can vindicate their free speech interests without impinging on the plaintiffs' property rights may reflect a certain solicitude towards those industries. By sharp contrast, plaintiffs in right of publicity cases are sometimes regarded with scorn and are not perceived to play the same integral role in the national economy. ${ }^{425}$ Typically, right of publicity claims are brought by wealthy individual celebrities or, worse yet, by their heirs. ${ }^{426}$ Vapid celebutantes, ${ }^{427}$ notorious sex symbols, ${ }^{428}$ divas and rockers, ${ }^{429}$ and pampered professional athletes ${ }^{430}$ may be beloved in the popular imagination, but in front of stern-faced judges, they may represent somewhat less than sympathetic plaintiffs, especially when their assertion of rights appears to clash with someone else's free speech.

The explanatory power of this theory has a number of fatal flaws, however. First, the right of publicity's strong First Amendment check is largely a product of recent judicial innovations-it has only existed in this strong form for the past two decades. ${ }^{431}$ In that time, it is hard to believe that the type of plaintiffs bringing such claims has changed dramatically. Second, as one of the authors of this Article recently chronicled, as celebrity culture came to appear more democratic and economically vital in the late twentieth century, judicial attitudes towards celebrity evolved as well. ${ }^{432}$ After becoming more favorably disposed to the right of publicity, courts introduced a series of doctrinal innovations, including postmortem rights, which strengthened the

facts/econdata.asp (last visited Sep. 23, 2012) (stating that in 2009 "the entertainment software industry's value added to the U.S. Gross Domestic Product ... was $\$ 4.9$ billion").

425 See, e.g., Memphis Dev. Found. v. Factors ETC., Inc., 616 F.2d 956, 959 (6th Cir. 1980) ("The desire to exploit fame for the commercial advantage of one's heirs is ... a weak principle of motivation. ... [M]aking the right of publicity inheritable would not significantly inspire the creative endeavors of individuals in our society.").

426 See Mark Bartholomew, A Right is Born: Celebrity, Property, and Postmodern Lawmaking, 44 CONN. L. Rev. 301, 354, 356 (2011).

427 See Kieran Crowley, Lindsay Lohan Wants $\$ 100 M$ over E-Trade Ad, N.Y. Post (Mar. 9, 2010, 2:32 AM), http://www.nypost.com/p/news/national/lohan_such_baby_jVdQWABj9z0MgX zCv1Nh1O.

428 See Lee v. Penthouse Int'l, Ltd., No. CV 96-7069 SVW (JGx), 1997 U.S. Dist. LEXIS 23893, at *1-3 (C.D. Cal. Mar. 20, 1997).

429 See Romantics v. Activision Publ'g, Inc., 574 F. Supp. 2d 758, 762 (E.D. Mich. 2008); Winter v. DC Comics, 69 P.3d 473, 476 (Cal. 2003); Kirby v. Sega of Am., Inc., 50 Cal. Rptr. 3d 607, 609-11 (Cal. Ct. App. 2006).

430 See ETW Corp. v. Jireh Publ'g, Inc., 332 F.3d 915, 918-19 (6th Cir. 2003); Montana v.

San Jose Mercury News, Inc., 40 Cal. Rptr. 2d 639, 639-40 (Cal. Ct. App. 1995).

431 See supra Part I.B.1.

432 See Bartholomew, supra note 426 , at 304. 
celebrities' (dead) hand. ${ }^{433}$ Therefore, the gap in judicial attitudes towards copyright and right of publicity plaintiffs may not be as large as first theorized.

Third, the nature of the plaintiffs and legitimacy of the interests they seek to protect fails to explain the treatment of First Amendment defenses in trademark law. Trademark protection is firmly accepted as a legitimate right. The industries that benefit from vigorous enforcement of trademark law are just as powerful and important to the United States economy, if not more so, than the content creation industries served by copyright. ${ }^{434}$ Nevertheless, as documented previously, courts tend to take a more favorable view of free speech defenses in trademark cases than in copyright cases. ${ }^{435}$ Thus, judicial perception of each regime's typical litigants is unlikely to be a determinative factor that explains the First Amendment's intellectual property triptych.

\section{Categorizing the Speech Interests at Stake}

Another potential explanation for these different approaches to free expression might rest on how courts characterize the speech interests at stake. This process could occur in two ways. First, in accord with traditional First Amendment analysis, the divergent treatment could be a function of whether courts view a particular intellectual property regime as content-neutral or content-based. A contentbased regime should face more exacting First Amendment scrutiny than a content-neutral one. ${ }^{436}$ Second, regardless of whether a particular intellectual property construct is considered content-based or content-neutral, the divergent treatment of expressive interests might stem from how the courts characterize the types of speech typically threatened by a particular intellectual property construct. For example, if courts view right of publicity claims as more likely to threaten "higher value" speech (e.g., political or noncommercial forms of speech historically deemed the most critical to the marketplace of ideas) than copyright infringement claims, courts would seemingly

433 See id. at $315-18$.

434 The Bureau of Customs and Border Protection estimates that counterfeiting of trademarked goods costs U.S. companies over $\$ 200$ billion each year. Stop Counterfeiting in Manufactured Goods Act, Pub. L. No. 109-181, 120 Stat. 285, 285 (codified as amended at 18 U.S.C. $\S 2320$ (2006)).

435 Compare supra Part I.A.1, with supra Part I.C.1.

436 See infra note 438. 
have a principled basis to support the current divide. ${ }^{437}$ Unfortunately, however, such a basis does not appear to exist.

\section{Content-Based or Content-Neutral?}

A judicial choice to categorize a particular system of intellectual property regulation as content-based or content-neutral could explain the sharp divergence in the treatment of speech-related defenses in trademark, copyright, and right of publicity cases. In general, contentbased regulations of speech are subject to a more rigorous level of constitutional analysis-strict scrutiny-than content-neutral regulations, which receive only intermediate scrutiny. ${ }^{438}$ In fact, contentbased restrictions on speech are "presumptively invalid" and must represent the least restrictive means of achieving a compelling government interest to survive judicial review. ${ }^{439}$ Courts give content-based regulations the least deference because such laws are frequently motivated by disagreement with the speaker as opposed to reasonable public policy choices. ${ }^{440}$ As a result, judges evaluating an intellectual property regime deemed content-based might be expected to give more credence to expression-based defenses than when evaluating one deemed content-neutral.

The caselaw on this subject, however, suggests that the contentbased/content-neutral distinction cannot explain the three regimes' doctrinal divergence. First, surprisingly few intellectual property decisions wrestle with this foundational distinction when addressing First Amendment concerns. Lisa Ramsey describes judicial treatment of this issue in the trademark arena as "cursory" at best. ${ }^{441}$ Those few opinions that have even addressed the issue have reached different conclusions as to whether trademark law is content-based or content-

437 By using the term "higher value," the authors do not make an independent judgment on the weight of various types of speech. Rather, this term simply reflects the Supreme Court's tendency to grant greater protection to certain forms of speech (e.g., political or noncommercial), see, e.g., Cohen v. California, 403 U.S. 15, 16-18 (1971) (reversing defendant's conviction resulting from his wearing of a jacket inscribed with the words "Fuck the Draft" on First Amendment grounds), over others (e.g., sexually explicit or commercial), see, e.g., F.C.C. v. Pacifica Found., 438 U.S. 726,743 (1978) (noting that "patently offensive references to excretory and sexual organs and activities ... lie at the periphery of First Amendment concern").

438 See United States v. Playboy Entm't Grp., Inc., 529 U.S. 803, 817 (2000); Christina Bohannan, Copyright Infringement and Harmless Speech, 61 Hastings L.J. 1083, 1107 (2010).

439 Playboy, 529 U.S. at 817 (internal quotation marks omitted).

440 See Geoffrey R. Stone, Content Regulation and the First Amendment, 25 WM. \& MARY L. Rev. 189, 227-33 \& nn.130-42 (1983).

441 See Ramsey, supra note 213 , at 431. 
neutral. ${ }^{442}$ Courts also seem to disagree over whether right of publicity laws are content-based and, in any event, most decisions simply ignore the issue. ${ }^{443}$ The issue also remains unresolved in copyright law. In Eldred, for example, the Supreme Court sidestepped the issue entirely when it rejected the petitioners' request for any form of heightened First Amendment scrutiny of the CTEA. ${ }^{444}$ Scholars have disagreed vociferously about whether copyright is content-based or content-neutral, ${ }^{445}$ and judicial guidance on this issue is unlikely to come anytime soon. The Supreme Court, perhaps the entity most likely to provide a thorough and influential examination of the constitutionality of these intellectual property rights, has only addressed the intersection of the First Amendment and intellectual property five times in the last forty years. ${ }^{446}$ Given the unsettled and infrequent treatment of this issue in reported decisions, the distinction between content-based and content-neutral seems unlikely to account for the differences described in Part $\mathrm{I}^{447}$

442 Compare Nissan Motor Co. v. Nissan Computer Corp., 378 F.3d 1002, 1016 (9th Cir. 2004) (concluding that injunction preventing use of plaintiff's trademark was content-based), with Dall. Cowboys Cheerleaders, Inc. v. Pussycat Cinema, Ltd., 604 F.2d 200, 206 (2d Cir. 1979) (concluding that Lanham Act provision prohibiting infringement is content-neutral).

443 See Zacchini v. Scripps-Howard Broad. Co., 433 U.S. 562, 578-79 (1977) (ruling that Ohio's right of publicity law did not violate the First Amendment but not identifying that law as content-based or content-neutral). Compare David Tan, Political Recoding of the Contemporary Celebrity and the First Amendment, 2 HARv. J. Sports \& ENT. L. 1, 13 (2011) ("[R]ight of publicity laws are not seen as content-based ... thus resulting in the bulk of case law on governmental action being unhelpful to an analysis of First Amendment issues in a publicity claim."), with David S. Welkowitz \& Tyler T. Ochoa, The Terminator as Eraser: How Arnold Schwarzenegger Used the Right of Publicity to Terminate Non-Defamatory Political Speech, 45 Santa Clara L. Rev. 651, $666 \mathrm{n} .85$ (2005) ("When the right of publicity is used to preclude particular expression (e.g., a particular likeness of a celebrity), it should be deemed a 'contentbased' restriction.").

444 Eldred v. Ashcroft, 537 U.S. 186, 218-21 (2003).

445 See, e.g., Ramsey, supra note 213 , at 432 \& nn.309-10 (collecting citations).

446 See Volokh, supra note 1 , at 698 . Volokh noted that only four Supreme Court cases addressed intellectual property and the First Amendment in this time period, but he wrote his article before the Court's 2011 Golan $v$. Holder decision. Volokh also notes that in the same period, the Court addressed five cases involving the First Amendment implications of the rather rare activity of flag burning. See id.

447 The weight of scholarly authority suggests that all of these regimes are content-based and, hence, deserving of greater First Amendment protection. See C. Edwin Baker, First Amendment Limits on Copyright, 55 V AND. L. Rev. 891, 939-40 (2002); Thomas .F. Cotter \& Irina Y. Dmitrieva, Integrating the Right of Publicity with First Amendment and Copyright Preemption Analysis, 33 Colum. J.L. \& ARTs 165, 190-94 (2010); Ramsey, supra note 213, at 433; Volokh, supra note 1, at 702-10. But see Netanel, supra note 2, at 47-53 (contending that copyright law is content-neutral). So if the courts wrestled with the distinction between contentbased and content-neutral, they would most likely conclude that all of these regimes deserve the same strict scrutiny analysis. 


\section{Considering the Defendant's Speech}

Another potential explanation may lie in how judges construe the speech interests impacted by the respective intellectual property regimes. In the rare instances when courts have actually tried to explain the disparate treatment of First Amendment defenses in right of publicity, trademark, and copyright claims, courts have noted differences in the kinds of speech restricted by each intellectual property right. ${ }^{448}$ Such explanations are both infrequent and unconvincing, however. Undoubtedly, the three doctrines cover different rights. But a closer look reveals that the differing scopes of these doctrines do not obviate the serious free speech concerns at play in all three regimes. In addition, the courts' justifications for the differences clash with some wellestablished principles of First Amendment law.

In the D.C. Circuit's opinion in Eldred $v$. Reno, ${ }^{449}$ for example, the court took pains to contrast trademark law to copyright law, finding that the latter does not present the same First Amendment problems as the former. ${ }^{450}$ The court recognized that, in San Francisco Arts \& Athletics, Inc. v. United States Olympic Committee ("SFAA"), 45 the Supreme Court had applied heightened First Amendment scrutiny to an ultimately rejected challenge to a federal statute that granted the U.S. Olympic Committee ("USOC") supertrademark protection in the word "Olympic."452 However, the D.C. Circuit distinguished SFAA and declined the plaintiff's invitation to apply heightened scrutiny to the CTEA. ${ }^{453}$ As the D.C. Circuit reasoned, while trademark law restricts the use of particular words and therefore "runs a substantial risk of suppressing ideas in the process," "454 copyright does not do the same. The court then blithely noted that "copyright protection cannot embrace ideas; it therefore does not raise the same concern under the First Amendment." "455

Such a distinction rings hollow, however, and cannot explain the courts' relatively more rigorous approach to First Amendment defenses in trademark disputes. First, when the Eldred suit finally

448 See supra note 35.

449 Eldred v. Reno, 239 F.3d 372 (D.C. Cir. 2001).

450 See id. at 375-76.

451 S.F. Arts \& Athletics, Inc. v. U.S. Olympic Comm., 483 U.S. 522 (1987).

452 See Eldred, 239 F.3d at 376. The San Francisco Arts \& Athletics case actually involved a specific provision of trademark law that grants the USOC certain exclusive rights over the word "Olympic" and various Olympic symbols. See S.F. Arts \& Athletics, 483 U.S. at 524.

453 See Eldred, 239 F.3d at 374, 376.

454 Id. at 376 (quoting S.F. Arts \& Athletics, 483 U.S. at 532).

455 Id. 
reached the Supreme Court, ${ }^{456}$ the decision did not acknowledge the distinction between trademark and copyright proffered by the D.C. Circuit. In addition, the D.C. Circuit opinion failed to recognize that copyright can restrict the use of particular words in particular sequences and that these particular sequences can carry specific meanings. Consider the sequence of words "happy birthday to you." Though the melody for the song of the same name is in the public domain, a claimed copyright on the lyrics (particularly this four word phrase $)^{457}$ enables the copyright holder to prevent the unauthorized reproduction or public performance of the song. ${ }^{458}$ No one would suggest that singing "felicitations on the anniversary of your birth" to the same melody is a perfect equivalent.

On a less facetious note, in contexts unrelated to copyright, the Supreme Court has recognized that the right to use certain words, rather than their synonyms, is fundamental to the exercise of First Amendment rights. In Cohen $v$. California, ${ }^{459}$ the Court famously overturned the conviction of Paul Robert Cohen for disturbing the peace when he entered a Los Angeles courtroom wearing a jacket bearing the words "Fuck the Draft." 460 In rejecting arguments that Cohen could have expressed his message using less offensive language, the Court noted: "[W]e cannot indulge the facile assumption that one can forbid particular words without also running a substantial risk of suppressing ideas in the process." 461 Both copyright and trademark (and the right of publicity for that matter) can prohibit the use of a particular expression, and First Amendment jurisprudence has consistently held that even such a limited prohibition may still violate the Constitution. ${ }^{462}$

Thus, an attempt to explain copyright law's comparative reluctance to recognize expression-based defenses cannot reasonably point to the ways in which speech interests in the three regimes are conceptualized. No clear precedent identifies any of the regimes as contentneutral or content-based, and courts appear to spend little time in in-

456 See Eldred v. Ashcroft, 537 U.S. 186 (2003).

457 Admittedly, the copyright only covers the lyrics when combined with the melody. See Robert Brauneis, Copyright and the World's Most Popular Song, 56 J. Copyright Soc'y U.S.A. 335, 367 (2009).

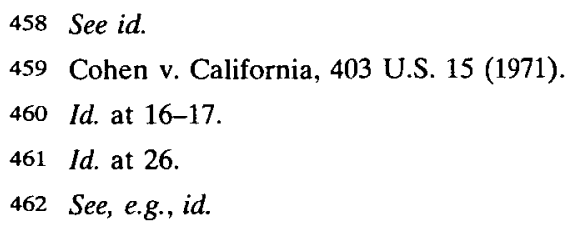


tellectual property cases agonizing over the difference. ${ }^{463}$ Additionally, an argument that the Lanham Act deserves greater scrutiny than the Copyright Act because the Lanham Act proscribes particular words makes little sense when considering either the operation of copyright law or the larger background of First Amendment jurisprudence. This Article must look elsewhere for an explanation.

\section{Common Law Versus Statutory Lawmaking}

This Article now turns from scrutiny of judicial language to the larger machinery of lawmaking. A clear difference exists in the source of legal authority for the three intellectual property rights at issue. This difference appears to explain, at least in part, the regimes' divergent approaches to free speech. Specifically, while the right of publicity is primaiily a creation of the common law, ${ }^{464}$ copyright and trademark law are principally guided by statute. ${ }^{465}$ These distinctive features of the three regimes impact their respective responses to speech-related defenses.

In so arguing, this Article builds on recent scholarship on the institutional design of intellectual property rights. As Shyamkrishna Balganesh has posited, intellectual property protections grounded in the common law possess certain characteristics that are less likely to appear in those grounded in statutes. ${ }^{466}$ First, common law rights or interests are more readily conceptualized by judges at a high level of abstraction. ${ }^{467}$ Moreover, such rights or interests are less likely to be grounded in precise language and more likely to be defined through value-neutral terms that require further definition by litigants and courts. ${ }^{468}$ As a consequence, common law regimes enjoy a pragmatic incrementalism that, through the vehicle of contestable concepts, makes them more nimble and adaptive than "one-size-fits-all statutory approaches." ${ }^{469}$

Second, common law regimes are more agile and responsive to an independent weighing of the goals of a particular regime against competing interests. ${ }^{470}$ Unlike statutes, the common law issues standards,

463 See supra Part II.C.1.

464 See Shyamkrishna Balganesh, The Pragmatic Incrementalism of Common Law Intellectual Property, 63 VAND. L. Rev. 1543, 1544-45 (2010).

465 See id. at 1551.

466 See id. at 1544-45.

467 See id. at 1574.

468 See id.

469 See id. at 1545, 1551.

470 See id. at 1549. 
not rules. ${ }^{471}$ This allows courts greater freedom to consider the particular facts at hand in a case and to assess the long-term impact of a decision on the overarching aims of the intellectual property system in question. ${ }^{472}$ In the process, courts are more able to consider multiple theoretical perspectives instead of remaining shackled to an exclusive theory of protection adopted by statute..$^{473}$

Balganesh does not offer an explanation of why this difference between common law and statutory intellectual property exists. One possible explanation is that once the words of an intellectual property defense are crystallized into statutory language, a single juridical construction of that language begins to crowd out other constructions. Another possible explanation is that statutes are typically accompanied with legislative commentaries and these commentaries might narrow the ideological debate surrounding statutory intellectual property. Whatever the reason, judges operating within the freedom of the common law appear better able to preserve a broad theoretical landscape, whereas statutory analysis restricts judicial autonomy and, concomitantly, has closed off potential avenues for addressing expressive concerns in copyright and trademark law. 474

\section{Publicity Rights and the Making of Common Law}

The right of publicity largely operates as a type of common law intellectual property. ${ }^{475}$ Many state legislatures have enacted statutory publicity rights, but this seems to have done little to slow the growth of their common law counterparts. ${ }^{476}$ The common law's more pluralistic approach helps explain the right of publicity's doctrinal innovations in favor of free expression. ${ }^{47}$

471 See id. at 1578 .

472 See id. at 1578-79.

473 See 1 MCCARTHY, supra note 205 , §§ 1:11, 1:16.

474 Common law design is not always superior to legislation, even in the intellectual property arena. Indeed, intellectual property regimes grounded in legislation enjoy certain advantages over common law ones. Legislation is particularly appropriate for fields where judicial competency may be lacking. The legislative process that gives rise to statutes also reflects greater democratic accountability. See Balganesh, supra note 464 , at 1592 . In addition, statutory architecture can help provide greater clarity, predictability, and certainty to litigants. See id. For further discussion of the respective capabilities of judges and legislators in crafting intellectual property rules, see David Fagundes, Crystals in the Public Domain, 50 B.C. L. REv. 139, 164-65 (2009).

475 See Pamela Samuelson, Enriching Discourse on Public Domains, 55 Duke L.J. 783, 796 (2006).

476 See Balganesh, supra note 464 , at 1558.

477 See supra Part I.B. 
Publicity rights have been conceptualized at an abstract level, allowing for flexibility and pragmatic adjustments in balancing expressive concerns with the interests of rights holders. Consider the vital role that the concepts of "transformativeness" and "newsworthiness" have played in recent right of publicity jurisprudence. Both terms have been left purposely vague, broad, and subject to significant judicial interpretative discretion. ${ }^{478}$ Their abstract nature allows for flexibility in decisionmaking. In general, common law adjudication gives courts greater freedom to introduce new doctrines without being hemmed in by old ones. ${ }^{479}$ The concept of newsworthiness, introduced to address situations in which celebrity personae were used for profit yet the uses needed to be allowed in the interest of public discourse, has become extremely important and frequently asserted in right of publicity cases. ${ }^{480}$ This defense emerged from whole cloth, ${ }^{481}$ a completely separate route to evaluate considerations of free expression apart from importing copyright fair use or applying the commercial/ noncommercial distinction.

In addition, the common law moorings of publicity rights have given courts the freedom to examine individual decisions in light of "the intended long term effects of the regime as a whole." 482 The common law's hospitability to searching inquiries as to the overarching concerns behind a particular legal right distinguishes it from statutory lawmaking ${ }^{483}$ and can fuel greater consideration of First Amendment interests. Consider Cardtoons v. Major League Baseball Players Ass'n. ${ }^{484}$ In rejecting a right of publicity claim brought by major league baseball players for the unauthorized use of their names and likenesses on a series of parodic baseball cards, the Tenth Circuit explicitly considered whether recognition of the card manufacturer's First Amendment defense would undermine the various goals of the publicity rights regime. ${ }^{485}$ The court identified the varying aims of the right of publicity as including encouraging investment in "creativity and achievement," protection against consumer deception, efficient allocation of societal resources, preservation of natural rights, and

478 See supra Part I.B.2.

479 See Balganesh, supra note 464, at 1547, 1549.

480 See Zac Locke, The Diminishing Power of California's Rights of Privacy and Publicity, L.A. Law., June 2010, at 12.

481 See supra Part I.B.2.b.

482 Balganesh, supra note 464, at 1589.

483 See id. at 1549-50.

484 Cardtoons, L.C. v. Major League Baseball Players Ass'n, 95 F.3d 959 (10th Cir. 1996).

485 See id. at 976. 
promotion of labor-desert. ${ }^{486}$ After a lengthy discussion, the court found that a ruling against the baseball players would minimally impact the overall aims of the system. ${ }^{487}$ For example, in addressing the investment theory of publicity rights, the court found that "it is unlikely that little leaguers will stop dreaming of the big leagues or major leaguers will start 'dogging it' to first base if MLBPA is denied the right to control the use of its members' identities in parody." 488 Findings such as these ultimately paved the way for the court's conclusion that the First Amendment interests of the defendant far outweighed the comparatively marginal consequences an adverse decision would have on the motivation of baseball players to achieve sustained excellence. ${ }^{489}$

\section{Copyright and the Limits of Statutory Lawmaking}

Copyright lawmaking presents a very different picture. Copyright law's governance by the explicit framework of the Copyright Act profoundly affects its ability to give independent consideration to speech-related defenses. Although it emerged from the common law and escaped explicit enunciation for more than a century, ${ }^{490}$ even the fair use doctrine - the chief vehicle for vindicating expressive interests in copyright law - has been codified since 1976.491 This codification has consequences. The statutory language and structure of fair use locks courts into a particular framework. Even though fair use permits the introduction of additional, unspecified factors, ${ }^{492}$ courts have rarely considered any additional factors beyond the four specific codified factors in their analysis. ${ }^{493}$ Moreover, when judges attempt to innovate by offering a new interpretation of one of the four longestablished factors, the other three factors operate as a check, restrict-

486 Id. at $973,975$.

487 See id. at $974,976$.

488 Id. at 974.

489 See id. at 974-75 (arguing that "additional inducement for achievement produced by publicity rights are often inconsequential" because most noteworthy celebrities are already highly compensated). The court maintained that the magnitude and importance of the incentives provided by publicity rights are "exaggerated" and that the "alternative means of communication" the MLBPA proposed were insufficient to "accommodate the public's interest in free expression." Id. at $971,974$.

490 See Folsom v. Marsh, 9 F. Cas. 342, 344-45, 348 (C.C.D. Mass. 1841); William McGinty, Comment, First Amendment Rights to Protected Expression: What Are the Traditional Contours of Copyright Law?, 23 Berkeley TECH. L.J. 1099, 1113 (2008).

491 See Act for the General Revision of the Copyright Law, Pub. L. No. 94-553, 90 Stat. 2541 (1976) (codified as amended at 17 U.S.C. $\$ 107$ (2006)) (codifying fair use factors).

492 See Beebe, supra note 144 , at 564 \& n.61.

493 See id. at 563-64. 
ing the innovative potential of the new interpretation. ${ }^{494}$ A second related consequence of the statutory framework is a general refusal to recognize the multiplicity of interests at stake in copyright disputes. ${ }^{495}$ Although statutory regimes, like their common law counterparts, may potentially employ facially value-neutral abstract language, the terms used in a statute are more susceptible to definition according to a single purpose or meaning than those found in common law decisions. ${ }^{496}$ This, argues Balganesh, is what happened with copyright fair use, which began using value-neutral language to incorporate a number of different theoretical justifications, but has come to be understood "almost entirely in market failure (or transaction cost related) terms."497

Castle Rock Entertainment v. Carol Publishing Group, Inc. ${ }^{498}$ provides an instructive example. In the suit, a federal court in New York acknowledged that a book of trivia about the Seinfeld television series was transformative for the purposes of the fair use test. ${ }^{499}$ As the court noted, the Seinfeld Aptitude Test ("SAT") met the Campbell Court's transformation test: "By testing Seinfeld devotees on their facility at recalling seemingly random plot elements from various of the show's episodes, defendants have 'added something new' to Seinfeld, and have created a work of a 'different character' from the pro-

494 See infra notes 498-506 and accompanying text.

495 Cf. Balganesh, supra note 464, at 1575 (noting that "common law intellectual property" can accommodate "value pluralism" that takes the form of a "contextual balancing and application of foundational values" whereas such pluralism occurs far less in "statutory intellectual property").

496 See id. at $1575 \&$ n.141. Even within statutory legal frameworks, some room still exists for the development of rules and interpretation of statutory provisions through a common lawlike analysis. See id. at $\mathbf{1 5 5 1}$. Examples of defenses to infringement created by judges within a statutory framework include the functionality doctrine in trademark law and the copyright misuse doctrine. See Qualitex Co. v. Jacobson Prods. Co., 514 U.S. 159, 164-65 (1995) (applying functionality doctrine defense); Lasercomb Am., Inc. v. Reynolds, 911 F.2d 970, 973 (4th Cir. 1990) (finding that a copyright misuse "defense is inherent in the law of copyright"). Such development is more readily achieved, however, when working within an exclusively common law framework.

497 Balganesh, supra note 464, at 1575 n.141; see also Beebe, supra note 144, at 617 ("The fourth factor essentially constitutes a metafactor under which courts integrate their analyses of the other three factors and, in doing so, arrive at the outcome not simply of the fourth factor, but of the overall test.").

498 Castle Rock Entm't v. Carol Publ'g Grp., Inc., 955 F. Supp. 260 (S.D.N.Y. 1997).

499 Id. at 268. On appeal, the district court's finding of infringement (and no fair use) was affirmed, but the Second Circuit held that the trivia book was not even transformative. Castle Rock Entm't, Inc. v. Carol Publ'g Grp., Inc., 150 F.3d 132, 143, 146 (2d Cir. 1998) ("Since The $S A T$ has transformed Seinfeld's expression into trivia quiz book form with little, if any, transformative purpose, the first fair use factor weighs against defendants."). 
gram."500 Despite this recognition of a broad definition of transformative use, however, the court still rejected the defendant's fair use defense and found infringement. ${ }^{501}$

Two points in the court's analysis are particularly relevant to this discussion of statutory versus common law regimes. First, the case illustrates how an established statutory framework can potentially strangle judicial innovation in its cradle. The court found that "without Seinfeld, there can be no SAT" and, as such, determined that the third element of the fair use test (amount of borrowing) strongly favored the plaintiff. ${ }^{502}$ Such reasoning nullifies the value of a finding of transformation in the fair use calculus. After all, no transformative use can ever exist without the original work. ${ }^{503}$ The court also found that the fourth element of the fair use test, market harm, ${ }^{504}$ weighed heavily in the plaintiff's favor. ${ }^{505}$ As the court reasoned, although the transformative $S A T$ did not hurt the demand for the Seinfeld television program, it harmed the market for derivative works such as trivia books that the owners of the Seinfeld copyright may potentially want to publish. ${ }^{506}$ Thus, even where transformative use is found, courts' typical readings of the other fair use factors can neuter the impact of such a finding. ${ }^{507}$ The traditional application of the other three statutory factors seems to inevitably swallow up any attempt to carve out new room for expression within one of the statutory factors.

Second, Castle Rock's emphasis on potential market harm to the copyright holder reveals how a statutory intellectual property framework dominated by a single theoretical justification can lack the nimbleness of its more ecumenical common law counterpart. Although transformative, the $S A T$ ultimately failed the fair use test in part due to the broad definition of market harm that holds sway in modern

500 Castle Rock, 955 F. Supp. at 268 (quoting Campbell v. Acuff-Rose Music, Inc., 510 U.S. 569, 579 (1994)).

501 See id. at 272 .

$502 I d$. at 270 .

503 Cf. Warner Bros. Entm't Inc. v. RDR Books, 575 F. Supp. 2d 513, 546-47 (S.D.N.Y 2008) (holding that, although encyclopedic guide to Harry Potter was transformative, it took "too much original expression" and was ultimately not a fair use).

504 The fourth factor assesses the "effect of the use upon the potential market for or value of the copyrighted work." 17 U.S.C. \$ 107(4) (2006).

505 See Castle Rock, 955 F. Supp. at 271-72.

506 See id.

507 This was not the only error committed by the Castle Rock court. As David Nimmer notes, the problematic interpretation of the fair use balancing test also went hand in hand with erroneous application of the substantial similarity doctrine. See David Nimmer, Codifying Copyright Comprehensibly, 51 UCLA L. REv. 1233, 1242 \& n.63 (2004). 
copyright jurisprudence. ${ }^{508}$ Because, in the court's view, the inquiry for market harm "must extend even to the potential market for as yet nonexistent derivative works," 509 virtually any transformative use would have harmed a potential derivative market for the Seinfeld television show. By focusing so intently on the possibility of market harm, the court ignored other potential interests at stake, particularly the expressive interests of the developers of the $S A T$ and the general public. This sort of judicial tunnel vision regarding copyright is by no means unusual. In sharp contrast to the Cardtoons court, which considered a variety of interests potentially impacted by its decision on the right of publicity, ${ }^{510}$ the court in Salinger $v$. Colting enjoined publication of 60 Years Later anywhere in the United States without even attempting to grapple with the various aims of the copyright system..$^{511}$ Rather, the only mention of the overarching goals of the copyright regime came through the court's mechanistic application of the statutory four-part balancing test, and then predominantly within the context of considering fair use's market harm factor. ${ }^{512}$ This analysis only considered the impact of an adverse ruling on copyright holders, not on copyright users. ${ }^{513}$ Without the common law's flexibility, which allows for a fuller consideration of the long-term import of their decisions, courts adjudicating copyright disputes tend to downplay, if not altogether ignore, the full implications of their rulings.

Eldred provides another illustration of this refusal to acknowledge copyright's multi-faceted nature. The twenty-year extension of copyright terms granted by the legislation at issue in Eldred had a monumental impact on the scope of the public domain and the rights of individuals to access cultural content and make expressive speech based on that content. ${ }^{514}$ Nevertheless, the Court brushed aside these concerns. There was no searching inquiry as to whether the CTEA

508 See Castle Rock, 955 F. Supp. at 268, 271-72.

509 Id. at 271; see also Campbell v. Acuff-Rose Music, Inc., 510 U.S. 569, 591-93 (1994) ("Evidence of substantial harm to a [derivative market] could weigh against a finding of fair use, because the licensing of derivatives is an important economic incentive to the creation of originals.").

510 See Cardtoons, L.C. v. Major League Baseball Players Ass'n, 95 F.3d 959, 967-76 (10th Cir. 1996).

511 Salinger v. Colting, 641 F. Supp. 2d 250, 268-69 (S.D.N.Y. 2009), vacated on other grounds, 607 F.3d 68 (2d Cir. 2010).

512 See id. at 256-68.

513 See, e.g., id. at 268 (applying four-part balancing test and finding "likely injury to the potential market for derivative works" of copyright holder).

514 See Eldred v. Ashcroft, 537 U.S. 186, 266-67 (2003) (Breyer, J., dissenting). 
actually did advance the overarching goals of the copyright regime..$^{515}$ Instead, the Court deferred heavily to Congress by applying only a mild form of rational basis review to the statute. ${ }^{516}$ "[W]e are not at liberty to second-guess congressional determinations and policy judgments of this order, however debatable or arguably unwise they may be," the Court explained. ${ }^{517}$ Similarly, in evaluating the constitutionality of section 514's grant of protection to preexisting works once deemed ineligible for copyright, the Court in Golan explained that "nothing in . . . our own jurisprudence warrants exceptional First Amendment solicitude for copyrighted works that were once in the public domain." ${ }_{518}$

Deference to Congress, the author of the statute controlling copyright law, also reinforces the overriding emphasis on market harm to the copyright holder. In wrestling with new uses of copyrighted works, the courts often remark that, if additional defenses based on alternative theoretical grounds are needed, Congress, not the courts, must step in to enact such defenses. ${ }^{519}$ But industry players concerned with (and aided by) the market-based approach have largely guided congressional activity in this area. ${ }^{520}$ Indeed, intellectual property legislation is notably susceptible to the lobbying of special interest groups. ${ }^{521}$ Hence, legislative contributions are unlikely to alter the basic contours of checks on rights in copyright law. Congress's input in the process, both in its construction of statutory language and its dialogue with the courts, merely reinforces the dominant conception of strong copyright as a necessary tool for incentivizing authorship and

515 See id. at 216 (majority opinion) ("'It is for Congress to determine if the present system' effectuates the goals of the Copyright and Patent Clause.").

$516 I d$. at 204 (noting that "we defer substantially to Congress" in determining whether the CTEA is "a rational exercise of the legislative authority conferred by the Copyright Clause").

517 Id. at 208.

518 Golan v. Holder, 132 S. Ct. 873, 891 (2012).

519 See, e.g., Authors Guild v. Google Inc., 770 F. Supp. 2d 666, 677 (S.D.N.Y. 2011). One notable exception is the Sony safe harbor, introduced by the Supreme Court in 1984, which immunizes manufacturers and distributors of products capable of substantial noninfringing uses from contributory copyright infringement liability. See Sony Corp. of Am. v. Universal City Studios, Inc., 464 U.S. 417, 442 (1984). But some have argued that Sony, as applied by the lower courts, has not done much to actually check the rights of copyright holders. See Peter S. Menell \& David Nimmer, Legal Realism in Action: Indirect Copyright Liability's Continuing Tort Framework and Sony's De Facto Demise, 55 UCLA L. Rev. 143, 172-77 (2007).

520 See Jessica D. Litman, Copyright, Compromise, and Legislative History, 72 Cornell L. REV. 857, 879 (1987).

521 See, e.g., Robert P. Merges, One Hundred Years of Solicitude: Intellectual Property Law, 1900-2000, 88 CALIF. L. REv. 2187, 2234-35 (2000) (referencing "abundant evidence" of increased focus (and spending) on lobbying on behalf of IP issues). 
overshadows other potential goals of copyright law, including free expression. ${ }^{522}$ By contrast, the right of publicity's judicially developed common law framework does not require such deference to the interests of legislative actors, thereby freeing the courts to introduce doctrinal reforms, like the transformativeness and newsworthiness defenses, that are largely unrelated to market-based concerns.

\section{Trademark Law: Statutory and Common Law Hybridity}

Trademark law lies somewhere between the statutory domain of copyright law and the common law preserve of publicity rights. Federal trademark law is governed by a statute-the Lanham Act. ${ }^{523} \mathrm{Al}$ though state trademark laws exist, they largely echo the provisions of the federal statute and do not represent true theoretical competitors. $^{524}$ In this sense, trademark law looks much like copyright law. On the other hand, "[l]egislatures have allowed, if not encouraged, courts to develop the common law of trademarks." 525 In addition, the Lanham Act gives the federal courts jurisdiction over both statutory claims involving federally registered trademarks and common law claims involving unregistered marks. ${ }^{526}$ Accordingly, courts commonly reference common law concepts when deciphering the content of parallel statutory provisions. ${ }^{527}$

Trademark law's approach to defenses based on free expression reflects its hybrid status-part common law and part statute. For example, trademark law's statutory language has cabined attempts to expand immunity for expressive acts. ${ }^{528}$ Due to this language, courts have narrowly construed defenses with the potential to insulate wide swaths of speech from liability. For example, courts have read the statutory descriptive fair use defense in a limited fashion when defendants have sought its application in the novel context of internet

522 See Dennis S. Karjala, Copyright Protection of Operating Software, Copyright Misuse, and Antitrust, 9 CoRnell J.L. \& PuB. Pol'y 161, 163 (1999) ("Congress has a ratchet for copyright protection that sends it in only one direction--more for owners of existing copyrights and less for current and future authors and for the public generally.").

52315 U.S.C. $\$ 1051$ (2006).

524 See Michael Grynberg, The Judicial Role in Trademark Law, 52 B.C. L. REv. 1283, 1332 n.232 (2011).

525 Ramsey, supra note 213, at 455; see also Dinwoodie, supra note 395, at 137-38.

526 See 15 U.S.C. $\$ 1121$ (a); see also Genesee Brewing Co. v. Stroh Brewing Co, 124 F.3d 137, 142 (2d Cir. 1997) (noting that section 43(a) of the Lanham Act "may protect unregistered marks from infringement").

527 See Dinwoodie, supra note 395, at 138.

528 See Michael Grynberg, Things Are Worse than We Think: Trademark Defenses in a "Formalist" Age, 24 Berkeley TeCh. L.J. 897, 918-19 (2009). 
search advertising. ${ }^{529}$ The defense is meant to encourage the communication of product information. ${ }^{530}$ Arguably, advertisers further the policies behind the defense when they purchase keywords incorporating the trademarks of other businesses from search engines like Google. ${ }^{531}$ An insurance company that sells a product similar to GEICO but at a cheaper price can use keyword search advertising to let consumers know that the product exists and offers a service comparable to the well-known brand. ${ }^{532}$ In some ways, this is analogous to a juice manufacturer informing consumers that its beverage is "sweettart." ${ }_{333}$ Both are taking advantage of efficient language to communicate valuable information to consumers. Yet an attempt to fit keyword search advertising into the descriptive fair use defense was rejected..$^{534}$

Also in keeping with statutory lawmaking, for the most part, trademark defenses are guided by a single theoretical construct-the need to protect consumers from confusion in the marketplace. ${ }^{535}$ Jessica Silbey has described trademark law as animated by a particular story of origin, one based on rational consumers seeking an identity relationship with producers and acting in a utility-maximizing fashion. ${ }^{536}$ Other concerns raised by trademark protection take a backseat to the goal of preventing a likelihood of confusion that might damage the bonds formed between consumers and producers. ${ }^{537}$

Courts' recent decisions regarding the descriptive and nominative fair use defenses exemplify this narrow view of trademark law and, in the process, carry direct implications for expressive rights. As discussed earlier, the Supreme Court's 2004 KP Permanent decision limits the effectiveness of the statutory descriptive fair use defense by allowing likelihood of confusion to be considered in determining

529 See id.

530 See 15 U.S.C. $\$ 1125$ (c)(3).

531 See Grynberg, supra note 528, at 919.

532 See id.

533 See Sunmark, Inc. v. Ocean Spray Cranberries, Inc., 64 F.3d 1055, 1057-58 (7th Cir. 1995).

534 Brookfield Commc'ns, Inc. v. W. Coast Entm't Corp., 174 F.3d 1036, 1065-66 (9th Cir. 1999) (search engine marketing); see also Eli Lilly \& Co. v. Natural Answers, Inc., 86 F. Supp. 2d 834,846 (S.D. Ind. 2000) (suggesting that fair use of a trademarked term in metatags could only possibly occur "in some unusual situations").

535 See 15 U.S.C. $\$ \S 1114,1125(a) ;$ Jessica Silbey, The Mythical Beginnings of Intellectual Property, 15 Geo. Mason L. Rev. 319, 360 (2008).

536 See Silbey, supra note 535, at 359-75.

537 See id. at 360-61 ("Trademarks are born of the identity-relation between consumer and manufacturer, the venerated origin of which is a frictionless and unambiguous market economy where free actors reign."). 
whether a defendant's use is "fair" in the first place. ${ }^{538}$ Much like the operation of copyright's fair use doctrine, the expressive interests at play in cases involving descriptive uses do not receive independent weight in trademark law. ${ }^{539}$ Instead, the goal of preventing consumer confusion inevitably takes center stage.

Similarly, the original promise of the nominative fair use analysis has not been fully realized because of the difficulty courts face in considering the defense independently from trademark's consumer protection rationale. Although Austin categorizes nominative fair use as an effort to protect speech, the Ninth Circuit has carefully avoided justifying its introduction of the nominative fair use test through reference to the First Amendment. ${ }^{540}$ Instead, the nominative fair use test receives its justification from the likelihood of confusion cause of action itself. ${ }^{541}$ As the court explained, it created the test to exempt that "class of cases where the use of the trademark does not attempt to capitalize on consumer confusion or to appropriate the cachet of one product for a different one." 542 Thus, nominative fair use sounds in the anticonfusion rationale of the trademark statute, not the speechprotection rationale of the First Amendment. As a result, the third part of the nominative fair use test-which only allows the defense if the alleged infringer has done nothing to "suggest sponsorship or endorsement by the trademark holder" 543 _ can easily collapse into a restatement of the likelihood of confusion factors. Unlike the descriptive fair use defense, nominative fair use is a common law doctrine, but its narrow construction may be influenced by judicial awareness of the principles animating its statutory cousin. ${ }^{544}$

On the other hand, given its hybrid nature, some room for common law maneuvering still remains in trademark doctrine. Although consumer protection seems to be the most frequently cited justification for trademark law, other considerations are sometimes brought forth. For example, courts have cited such alternative concerns as enforcing a certain form of commercial morality, rewarding the invest-

$5385 e$ KP Permanent Make-Up, Inc. v. Impression I, Inc., 543 U.S. 111, 121, 123 (2004).

539 See McGeveran, supra note 212, at 84-85.

540 See Grynberg, supra note 528, at 957 \& n.262; see also Mattel Inc. v. Walking Mountain Prods., 353 F.3d 792, 808 \& n.14 (9th Cir. 2003) (electing to decide case on basis of nominative fair use defense rather than conducting First Amendment analysis).

541 See Grynberg, supra note 528, at 956-57; Gulasekaram, supra note 328, at 921.

542 New Kids on the Block v. News Am. Publ'g, Inc., 971 F.2d 302, 307-08 (9th Cir. 1992).

543 See id. at 308.

544 See Vanessa P. Rollins, Trademark Fair Use: Braun® Versus the Bunny, 13 MARQ. IN. TEll. Prop. L. Rev. 285, 294-95 \& n.42 (2009) (describing both defenses as stemming from the same "underlying expressive and competitive principles"). 
ment of mark holders in product quality, and providing more choices for consumers. ${ }^{545}$ In addition, unlike copyright law with its rigid focus on fair use, the courts appear to have some freedom to introduce exceptions to trademark infringement outside of statutory defenses. Both the nominative fair use defense ${ }^{546}$ and the Rogers test ${ }^{547}$ represent judicial innovations outside of the statutory structure. Although the growth of the nominative fair use test has been stunted, perhaps because of its close relationship with the statutory descriptive fair use test, ${ }^{548}$ the Rogers test relies on expansive language that courts can refine and adapt. The first prong of the test interrogates "artistic relevance," a remarkably broad concept that gives judges a great deal of leeway in deciding these cases. .49

Moreover, while courts usually address free speech interests within the framework of existing, trademark-specific defenses, they occasionally bring the First Amendment into service when evaluating defenses based on expression. ${ }^{550}$ This practice stands in marked contrast to copyright law, where the statutory enshrinement of the fair use test appears to foreclose independent consideration or weighing of First Amendment interests. ${ }^{551}$ In sum, trademark doctrine is a mixed bag. On one hand, it clings tightly to its statutory mandate to prevent consumer confusion-a tack that closes off development of some potentially defendant-friendly mechanisms for vindication of First Amendment rights. On the other hand, it offers some doctrinal innovations, particularly the Rogers test, that can consider and promote free speech.

545 See, e.g., Playboy Enters., Inc. v. Netscape Commc'ns. Corp., 354 F.3d 1020, 1035 (9th Cir. 2004) (Berzon, J., concurring) (discussing value of consumer choice); Warner Bros. Co. v. Jantzen, Inc., 249 F.2d 353, 356 (2d Cir. 1957) (Lumbard, J., dissenting) ("Judicial protection of trademarks is not static; it changes with changing concepts of commercial morality."). For a more detailed discussion of the other interests, besides prevention of consumer confusion, at stake in trademark law, see Graeme B. Dinwoodie \& Mark D. Janis, Confusion over Use: Contextualism in Trademark Law, 92 IowA L. Rev. 1597, 1638-41 \& n.178 (2007).

546 See New Kids, 971 F.2d at 307-08.

547 See Rogers v. Grimaldi, 875 F.2d 994, 999 (2d Cir. 1989).

548 See Grynberg, supra note 528 , at $956-58$.

549 See Rogers, 875 F.2d at 999.

550 See, e.g., S.F. Arts \& Athletics, Inc. v. U.S. Olympic Comm., 483 U.S. 522, 536-41 (1987); Nissan Motor Co. v. Nissan Computer Corp., 378 F.3d 1002, 1016 (9th Cir. 2004); see also supra note 287.

551 See Eldred v. Ashcroft, 537 U.S. 186, 218-21 (2003). 


\section{E. The Influence of Tradition}

It is not just the mode of lawmaking that helps construct intellectual property's defensive architecture, but also the particular tradition undergirding a given right. In Eldred, the Supreme Court explained that First Amendment scrutiny is only appropriate when a copyright regulation fundamentally alters the "traditional contours of copyright protection." 552 Otherwise, constitutional review is unnecessary. ${ }^{553}$ The Court concluded that a twenty-year extension of the copyright term was well within these "traditional contours." 554 Hence, it was the Justices' particular interpretation of copyright's tradition that determined whether courts should give any independent consideration to expressive concerns.

While many commentators have criticized the "traditional contours" language, ${ }^{555}$ judicial reliance on tradition is certainly not unusual. Tradition is frequently invoked in legal decisionmaking, particularly in constitutional law. ${ }^{556}$ More importantly for the purposes of this Article, judges also refer to particular traditions to justify decisions involving intellectual property rights and expression-based defenses. Differences in the nature of these traditions and the manner in which they are invoked may account for some of the divergence described in Part I. This Section examines two ways in which tradition influences the intellectual property/First Amendment interface. The first is how each regime approaches legal precedent. The second is how each regime responds to larger histories, both in chronicling legislative activity and in accounting for and reflecting larger social and cultural forces.

\section{Precedent and Path Dependence}

One way to account for the different free expression paths traveled by these three intellectual property regimes is to point to key

552 See id. at 221.

$553 I d$.

554 Id. at 186, 221-22 (referring to the constitutionality of the CTEA, the court concluded that it "remains inside the domain the Constitution assigns to the First Branch").

555 See, e.g., Paul Bender, Copyright and the First Amendment After Eldred v. Ashcroft, 30 Colum. J.L. \& ArTs 349, 350-51 (2007); J. Matthew Miller III, Comment, The Trouble with Traditions: The Split over Eldred's Traditional Contours Guidelines, How They Might Be Applied, and Why They Ultimately Fail, 11 Tul. J. TeCH. \& INTELl. Prop. 91, 108-09 (2008).

556 See, e.g., Katharine T. Bartlett, Tradition, Change, and the Idea of Progress in Feminist Legal Thought, 1995 WIS. L. REv. 303, 308-19 (tracing the use of tradition in the Supreme Court's family law jurisprudence); Ellen E. Sward, Justification and Doctrinal Evolution, 37 ConN. L. Rev. 389, 418-24 (2004) (describing use of "historical justification" for various legal doctrines). 
precedents that have steered them in different directions. The United States legal system revolves around respect for previous judicial decisions. ${ }^{557}$ Some theorize that this respect for precedent intensifies when property rights are involved as judges are particularly keen to promote social stability by hewing closely to traditional property rules. ${ }^{558}$ A particular precedent's influence can be felt for a long time, and change comes slowly. ${ }^{559}$ Although some have championed the common law's approach to precedent because it allows only the best precedents to survive in the long run, others suggest that the legal system's path dependence can result in static and inefficient outcomes. ${ }^{560}$ Once a court sets a precedent, it becomes difficult for other courts to stray from that path. ${ }^{561}$ The initial conditions surrounding a precedential decision (even if not relevant to subsequent decisions), a judge's stray published comment, or merely the order in which particular cases are litigated can haphazardly shape the law for years to come. ${ }^{562}$

Precedent and path dependence may be a factor in the three regimes' divergent approaches to free expression. Take, for example, the fair use doctrine's overemphasis on market-based factors in copyright law. ${ }^{563}$ In an empirical analysis, Barton Beebe has found that courts evaluating the first fair use factor pay far more attention to the commerciality of the defendant's use than its transformativeness. ${ }^{564}$ Some courts even apply language from the Supreme Court's 1984 Sony Corp. of America v. Universal City Studios, Inc. ${ }^{565}$ decision suggesting that commercial uses are presumptively unfair. ${ }^{566}$ The Supreme Court backed away from this presumption, however, in subsequent decisions in 1985 and 1990 and even found that such a presumption was not good law in its 1994 Campbell decision. ${ }^{567}$ Beebe theorizes that "[t]he sheer mass of this precedent, perhaps even re-

557 See Oona A. Hathaway, Path Dependence in the Law: The Course and Pattern of Legal Change in a Common Law System, 86 IowA L. Rev. 601, 627-28 (2001).

558 See Dagan, supra note 420, at 19.

559 See Hathaway, supra note 557, at 640.

560 See id. at 638.

561 See id.

562 See Lawrence A. Cunningham, The Common Law as an Iterative Process: A Preliminary Inquiry, 81 Notre Dame L. Rev. 747, 749-50 (2006); Hathaway, supra note 557, at 647-50.

563 See supra Part I.A.3.b.

564 Beebe, supra note 144, at 597-98.

565 Sony Corp. of Am. v. Universal City Studios, Inc., 464 U.S. 417 (1984).

566 Beebe, supra note 144 , at $600-02$.

567 See Campbell v. Acuff-Rose Music, Inc., 510 U.S. 569, 585 (1994); Beebe, supra note 144 , at 599-600. 
gardless of what it said, appears to have kept the commerciality inquiry in the foreground of the factor one fair use analysis." 568 Similarly, in its 1985 Harper \& Row decision, the Court declared that "the effect of the use upon the potential market" for the copyright holder's work was "undoubtedly the single most important element of fair use." ${ }_{69}$ Even though the Campbell Court subsequently rejected this approach, explaining that all of the fair use factors are weighed together and that their importance will change according to context, ${ }^{570}$ courts continue to state that factor four is the most important. ${ }^{571}$ Harper \& Row featured undeniable proof of market harm from the defendant's use (a revoked licensing deal for the work at issue) and a defendant who appeared to act in bad faith (by publishing a purloined copy of an unpublished work to scoop a rival). ${ }^{572}$ Perhaps a case with a more sympathetic defendant, or more equivocal evidence of market harm, might have led to a different analysis that could have steered copyright's approach to free expression in a different direction. Instead, thirty years later, fair use jurisprudence continues to feel the effects of the initial conditions in the Harper \& Row litigation that caused a Supreme Court majority to side with the plaintiff. ${ }^{573}$

At the same time, one should not make too much of path dependence. Although the United States legal system relies on precedent, and that precedent can emerge from idiosyncratic conditions and considerations, the system also allows for the introduction of new legal rules when new social, economic, or legal forces place sufficient pressure on the old regime. ${ }^{574}$ A classic example is Justice Cardozo's opinion in MacPherson v. Buick Motor Co. ${ }^{575}$ The MacPherson decision rejected precedent holding that, unless inherently dangerous goods were involved, original sellers of defective goods had no liability to anyone harmed by the goods beyond the original purchaser. ${ }^{576} \mathrm{Re}-$ sponding to an increasingly impersonal and industrialized society, Cardozo decided that a manufacturer can be liable in negligence to

568 Beebe, supra note 144 , at 600 .

569 Harper \& Row, Publishers, Inc. v. Nation Enters., 471 U.S. 539, 566 (1985) (internal quotation marks omitted).

570 See Campbell, 510 U.S. at 578.

571 See Beebe, supra note 144 , at 617.

572 See Harper \& Row, 471 U.S. at 542, 568.

573 See Beebe, supra note 144 , at 617.

574 See Cunningham, supra note 562, at 777.

575 MacPherson v. Buick Motor Co., 111 N.E. 1050 (N.Y. 1916).

576 See id. at $1053,1055$. 
anyone for harm that could be reasonably expected from a defective product. 577

Some of the most important cases addressing the intellectual property/First Amendment interface also represent departures from prior holdings. Despite the Supreme Court's Zacchini v. ScrippsHoward Broadcasting Co. ${ }^{578}$ decision in 1977, which held that the publicity rights of an entertainer trumped the First Amendment interests of a television news station, ${ }^{579}$ subsequent decisions like Comedy III and Winter embrace expansive new defenses for expressive appropriations of celebrity. ${ }^{580}$ In the trademark context, lower courts created the Rogers and nominative fair use tests shortly after the Supreme Court determined in SFAA that the First Amendment did not prohibit Congress from amending trademark law to give the Olympic Committee exclusive rights to use the word "Olympic." 581 These judicial innovations are all the more striking since Zacchini and $S F A A$ are the only Supreme Court decisions addressing the interface between the right of publicity, trademark law, and the First Amendment. So although the timing and order of particular cases may affect doctrine, these factors are not determinative. Instead, another type of tradition recognized by courts may play a more significant role.

\section{Using History to Address Free Speech}

Tradition's role in legal decisionmaking can involve much more than mere compliance with a particular precedent; it also extends to shaping justifications based on a doctrine's overall longevity or relationship to a history of legislative activity. ${ }^{582}$ Under the traditionalist rubric, societal adherence to a particular way of doing things inherently justifies continuing to do things in that way. ${ }^{583}$ Although the legal system's obeisance to precedent also involves respect for prior events, it is different from the traditionalist model in that a precedent's persuasive value decreases over time. ${ }^{584}$ For the traditionalist,

577 ld. at 1053; Prosser \& Keeton on the Law of Torts 682 (W. Page Keeton et al. eds., 5th ed. 1984).

578 Zacchini v. Scripps-Howard Broad. Co., 433 U.S. 562 (1977).

579 Id. at $576-78$.

580 Winter v. DC Comics, 69 P.3d 473, 478-79 (Cal. 2003); Comedy III Prods., Inc. v. Gary Saderup, Inc., 21 P.3d 797, 808-10 (Cal. 2001).

581 S.F. Arts \& Athletics, Inc. v. U.S. Olympic Comm., 483 U.S. 522, $535-40$ (1987); see also New Kids on the Block v. News Am. Publ'g, Inc., 971 F.2d 302, 308 (9th Cir. 1992); Rogers v. Grimaldi, 875 F.2d 994, 999 (2d Cir. 1989).

582 See Bartlett, supra note 556, at 306-09 \& n.7.

583 See Sward, supra note 556 , at 418.

584 See Bartlett, supra note 556, at 307. 
however, the length of time a doctrine has been in use represents the critical justification for the doctrine's continued use. ${ }^{585}$

This reasoning is undeniably at work in all three regimes at issue. Eldred's discussion of "traditional contours" in copyright is one example, ${ }^{586}$ but trademark law and even right of publicity cases make similar appeals to the force of past practice. The descriptive fair use defense, which allows use of another's trademark to describe one's own business, has been justified on the basis of "longstanding and integral principles of trademark law" designed to promote free competition. ${ }^{587}$ The right of publicity has been justified as growing out of the traditional valuation of personal privacy. ${ }^{588}$ Even though intellectual property law is often described as rooted in the desire to optimize innovation, ${ }^{589}$ tradition and history also play a key role in its doctrinal evolution. ${ }^{590}$

The force of a traditionalist argument regarding the proper baiance between intangible property rights and free expression does seem stronger in copyright law, however, than in other contexts. Although defining a legal tradition is a tricky matter, ${ }^{591}$ copyright claims definitely have a longer heritage than the other intellectual property regimes at issue. Congress passed the first federal copyright law in 1790.592 Copyright's built-in safeguards for free speech, the fair use doctrine, and the idea/expression dichotomy have also existed for a long time. The fair use doctrine has been a part of American copy-

585 See David Luban, Legal Traditionalism, 43 Stan L. Rev. 1035, 1043 (1991) (distinguishing between precedent and tradition); see also Sward, supra note 556, at 421 (noting that the length of time a doctrine is used is also key to historical justifications in the law).

586 See Eldred v. Ashcroft, 537 U.S. 186, 221 (2003); Stephen M. McJohn, Eldred's Aftermath: Tradition, the Copyright Clause, and the Constitutionalization of Fair Use, $10 \mathrm{MıCH}$. Telecomm. \& Tech. L. Rev. 95, 107 (2003).

587 Pilates, Inc. v. Current Concepts, Inc., 120 F. Supp. 2d 286, 305 \& n.15 (S.D.N.Y 2000) (quoting Genesee Brewing Co. v. Stroh Brewing Co., 124 F.3d 137, 145 (2d Cir. 1997)) (internal quotation marks omitted).

588 See Toffoloni v. LFP Publ'g Grp., LLC, 572 F.3d 1201, 1205 (11th Cir. 2009).

589 See, e.g., Gaia Bernstein, In the Shadow of Innovation, 31 CARdozo L. REv. 2257, 2259-60 (2010).

590 See Paul A. David, Intellectual Property Institutions and the Panda's Thumb: Patents, Copyrights, and Trade Secrets in Economic Theory and History, in Global Dimensions of Intellectual Property Rights in Science and Technology 19, 44 (Mitchel B. Wallerstein et al. eds., 1993) ("[A]lthough the history of intellectual property rights in the West is replete with instances of redefinition and reinterpretation in response to pressures to accommodate or advance the economic interests of those most affected by the laws, many of the structure's gross features continue to reflect the remote historical circumstances in which they originated.").

591 See J.M. Balkin, Tradition, Betrayal, and the Politics of Deconstruction, 11 CARdozo L. REv. 1613, 1618 (1990) (discussing the multivalent nature of tradition).

592 See Copyright Act of 1790, ch. 15, 1 Stat. 124. 
right law since 1841,593 and the idea/expression dichotomy dates back at least to the landmark nineteenth-century case of Baker v. Selden. ${ }^{594}$ In contrast, Congress did not pass the first federal law regulating trademark until 1870,595 and the Supreme Court declared it unconstitutional just a few years later. ${ }^{596}$ Although a body of state trademark law existed in the early nineteenth century, it remained in a primitive state until the early twentieth century. ${ }^{597}$

Courts' relative openness to First Amendment checks on the right of publicity may also have a temporal dimension. Although copyright law is as old as the Republic, ${ }^{598}$ the right of publicity is largely an innovation of the past half century-one still gaining traction and legitimacy. The right was first applied in 1953, and decades passed before a majority of states recognized it. ${ }^{599}$ In many jurisdictions, the right is not recognized at all. ${ }^{600}$ Given this historical background, courts may believe they have greater freedom to construct defenses to the right, especially when the specter of a First Amendment violation is raised.

Moreover, copyright is unique in that the first federal copyright law and the First Amendment were enacted in the same time frame. ${ }^{601}$

593 See Folsom v. Marsh, 9 F. Cas. 342, 344-45, 348 (C.C.D. Mass. 1841); McGinty, supra note 490 , at 1129 . The fair use defense was not codified, however, until the Copyright Act of 1976. See Act for the General Revision of the Copyright Law, Pub. L. No. 94-553, 90 Stat. 2541 (1976) (codified as amended at 17 U.S.C. $\$ 107$ (2006)).

594 See Baker v. Selden, 101 U.S. 99, 103-04 (1879).

595 Act of July 8, 1870, ch. 230, 16 Stat. 198, $210 \S \S 77-84$.

596 See Trade-Mark Cases, 100 U.S. 82, 82 (1879).

597 Bone, supra note 414, at 576, 578; see also David L. LANGe \& H. JefFerson PowelL, No Law: Intellectual Property in the Image of an Absolute First Amendment 150-51 (2009).

598 See U.S. Const. art. I, $\$ 8$, cl. 8.

599 The right was first recognized in the case of Haelan Labs., Inc. v. Topps Chewing Gum, Inc., 202 F.2d 866, 868 (2d Cir. 1953); see also Stacey L. Dogan \& Mark A. Lemley, What the Right of Publicity Can Learn from Trademark Law, 58 STAN. L. REv. 1161, 1172-74 (2006) (describing the spread of recognition of the right of publicity following Topps).

600 See Semeraro, supra note 407, at $763 \mathrm{n} .49$ (listing twelve states that have not recognized a right of publicity).

601 See Eldred v. Ashcroft, 537 U.S. 186, 219 (2003). Along these lines, explanatory weight may also exist in the grounding of the respective intellectual property protections within the vertical hierarchy of federalism. Specifically, copyright law has constitutional origins and is exclusively controlled by federal law. This may suggest less potential incompatibility with the First Amendment. By contrast, trademark law lacks explicit constitutional origins and is governed by both federal and state law. As such, courts may be more willing to check its protections with First Amendment defenses. Finally, the right of publicity is wholly a creature of common law and state statutes. It is thus entitled to no constitutional deference and, as a result, it may not be surprising that courts lack compunction about giving the right independent First Amendment scrutiny. 
The Eldred majority relied on this observation to maintain that copyright laws and the First Amendment operate harmoniously in all but the most unusual circumstances. ${ }^{602}$ Because the First Amendment and the Copyright Act of 1790 were enacted contemporaneously, the Court seemed to reason, the legislators who passed both laws did not believe the two laws required any further reconciliation-a judgment to which the Court should give deference. ${ }^{603}$ These early legislators did not pass laws protecting trademarks or the right of publicity and, thus, one cannot argue that the balance between these rights and the First Amendment had been assessed (and, by implication, perfected) by the First Congress. ${ }^{604}$

This history may explain why courts continue to rely exclusively on the idea/expression dichotomy and the fair use defense to resolve First Amendment issues in copyright cases. Ellen Sward suggests that the use of historical justifications in legal arguments constrains doctrinal evolution. ${ }^{605}$ By contrast, pragmatic approaches to legal argument tend to allow more experimentation in doctrinal development. ${ }^{606} \mathrm{By}$ its nature, the traditionalist approach places the burden of proof on those seeking to change doctrine. Although pragmatic concerns, often brought to the surface by social change, can and do overcome traditionalist arguments, a legal doctrine anchored by a particularly strong

602 See id. at 219.

603 See id.; see also Bartlett, supra note 556, at 313-17 (discussing a particular mode of legal traditionalism that uses the history of a specific time to show the intent of a particular set of individuals).

604 Justifying a laissez-faire approach to expressive interests in copyright cases by the close timing of the enactment of the Copyright Act and the First Amendment is problematic. First, although traditionalist arguments are found throughout the law, First Amendment jurisprudence is particularly antitraditional as analysis of the First Amendment has evolved over time to protect various forms of historically unprotected speech. See Bender, supra note 555, at 351. Second, despite the Supreme Court's pronouncements on the subject, copyright today is hardly the same doctrine it was in 1787 . In the eighteenth century, copyright was a narrow law only prohibiting wholesale piracy. See Neil Weinstock Netanel, Impose a Noncommercial Use Levy to Allow Free Peer-to-Peer File Sharing, 17 HARv. J.L. \& TECH. 1, 24-25 (2003). Copyright law was very limited in duration (fourteen years), subject matter (maps and books), and scope (literal one-toone reproductions). See Copyright Act of 1790, ch. 15, 1 Stat. 124. Today, copyright law has expanded dramatically along all three dimensions: it lasts for the lifetime of an author plus seventy years, it covers any work of authorship fixed in a tangible medium, and it extends to reproductions, distributions, public displays, public performances, and derivatives containing even the smallest appropriations, whether literal or not. See 17 U.S.C. $\$ \S 102,106,302$ (a) (2006). Hence, the balance between copyright and the First Amendment supposedly struck at the end of the eighteenth century looks nothing like the (im)balance existing at the beginning of the twenty-first.

605 See Sward, supra note 556, at 489.

606 See id. at 490. 
historical pedigree can be more difficult to dislodge than one without such a pedigree. ${ }^{607}$ Copyright law's greater receptivity to traditionalist arguments, along with its relatively unyielding statutory framework, may be another weight on the scale that makes copyright resistant to change. With less material on which to build a traditionalist argument, right of publicity and trademark law are freer to turn to more prudential considerations and dynamic interventions. ${ }^{608}$

\section{CONCLUSION}

Judicial attempts to balance free expression with intellectual property protection differ radically depending on the intellectual property right at issue. The First Amendment is specifically invoked in right of publicity cases, but copyright and trademark doctrines prefer to address expressive concerns through internal judge-made and statutory defenses. In invoking the First Amendment, the right of publicity calculates transformative use generously and makes such use a complete defense to claims of infringement, even when there is accompanying evidence of market harm to the plaintiff. Meanwhile, copyright law, as evident in the fair use doctrine's rigid distinction between parody and satire, privileges only those uses that can be claimed as "necessary." Courts have construed trademark law's Rogers test so as to immunize artistic uses but, at the same time, the test's effectiveness is compromised by a continuing emphasis on consumer confusion and dependence on an amorphous distinction between commercial and noncommercial use.

Little attention has been paid, either by judges or academics, to the disparity in how each regime resolves the tension between property rights and the First Amendment. This is a mistake. This Article demonstrates that the disparity is not motivated by principled concerns over the various intellectual property rights and speech interests at issue. Rather, the differences between statutory and common law legal development, as well as the history of each intellectual property regime, shape current efforts to adapt intellectual property rights to new modes of expression. One insight from this study is that those

607 Cf. id. at 480 (noting that a historical justification amounting to "an appeal to an epochal period in our history" is "perhaps a more significant constraint" to legal change).

608 Traditionalism may not be the only mode of argument that discourages innovation. In the trademark context, scholars have also criticized textualist arguments for locking courts into wooden interpretations of statutes that do not do enough to protect free speech. See Grynberg, supra note 528, at 933-45; see also Philip BobBitT, Constitutional Fate: Theory of The Constitution 36-37 (1982) (maintaining that exclusive reliance on textual arguments leaves judges unable to make needed corrections to legal doctrines). 
looking for the most effective means of safeguarding expressive interests may conclude that judges, rather than legislators, are best equipped to counteract the natural conservatism brought on by age. For the right of publicity, its entirely judge-made rules for balancing expressive conduct with property interests are the most speech friendly of the three intellectual property regimes. Most importantly, the foregoing shows that more explicit analysis of the free expression triple standard is needed. Good reasons may exist for treating expressive uses more generously in one regime than in another, but these reasons should be fully articulated and brought to the fore instead of being silently generated by the machinery of the legal system. 